\title{
The Contribution of Innate Immunity to the Pathogenesis of ANCA-associated Vasculitis
}

\section{Daniel Söderberg}

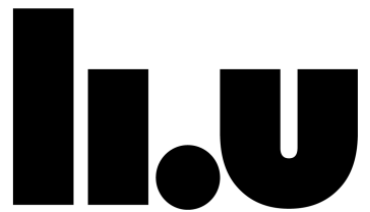

LINKÖPING UNIVERSITY

Division of Drug Research

Department of Medical and Health Sciences

Linköping University, Sweden

Linköping 2016 
CC Daniel Söderberg, 2016

Cover image: Neutrophils releasing neutrophil extracellular traps (NETs).

Modified from: Söderberg, D. and M. Segelmark, Neutrophil Extracellular Traps in ANCAassociated Vasculitis. Front Immunol, 2016. 7: p.256, with permission according to the Creative Commons Attribution License (CC-BY 4.0).

Published articles have been reprinted with permission from the copyright holders.

Paper 1: Oxford University Press.

Paper II: John Wiley \& Sons, Inc.

During the course of the research underlying this thesis, Daniel Söderberg was enrolled in the National Clinical Research School in Chronic Inflammatory Diseases at Karolinska Institute (KI), Stockholm, Sweden

ISBN 978-91-7685-659-8

ISSN 0345-0082

Printed by Liu-Tryck in Linköping, Sweden, 2016 
"Nog finns det mål och mening med vår färd men det är vägen som är mödan värd”

- Karin Boye 


\section{Supervisor}

Mårten Segelmark, Linköping University, Sweden

\section{Co-supervisors}

Per Eriksson, Linköping University, Sweden

Jan Ernerudh, Linköping University, Sweden

Tino Kurz, Linköping University, Sweden

\section{Faculty opponent}

Peter Heeringa, University of Groningen, The Netherlands 


\section{Abstract}

Anti-neutrophil cytoplasmic antibody (ANCA)-associated vasculitis (AAV) constitute a group of vasculitides characterized by neutrophil-rich necrotizing inflammation of small vessels and the presence of ANCA in the circulation. Dying neutrophils surrounding the walls of small vessels are a histological hallmark of AAV. Traditionally it has been assumed that these neutrophils die by necrosis, but neutrophil extracellular traps (NETs) have recently been visualized at the sites of vasculitic lesions. NETs were first described to be involved in capture and elimination of pathogens but dysregulated production and/or clearance of NETs are thought to contribute to vessel inflammation in AAV; directly by damaging endothelial cells and indirectly by acting as a link between the innate and adaptive immune system through the generation of pathogenic PR3-ANCA and MPO-ANCA that can activate neutrophils. ANCA can, however, be found in all individuals and are therefore suggested to belong to the repertoire of natural antibodies produced by innate-like B cells, implying that not all ANCA are pathogenic.

In paper I, we found neutrophils in patients to be more prone to undergo NETosis/necrosis spontaneously compared with neutrophils in healthy controls (HC), as well as that active patients possessed elevated levels of NETs in the circulation. Our results also suggest that ANCA during remission could contribute to the clearance of NETs as we observed an inverse relation between ANCA and NETs. In paper II, we observed neutrophils in patients to be more easily activated upon ANCA stimulation as they produced more ROS than neutrophils in HC. In paper III, we showed for the first time that cells of adaptive immunity (B and T cells) in addition to cells of innate immunity can release ET-like structures, in this case consisting of mitochondrial (mt) DNA. mtDNA can act as a damage-associated pattern molecule (DAMP) and promote inflammation, and increased levels of mtDNA has been observed in AAV. Our finding broadens our perspective of the possible roles of T and B cells in immunological responses, and should be further investigated in AAV. In paper IV, we observed reduced frequencies of MZ-like B cells, considered to be innate-like B cells that produce natural antibodies, and of the proposed regulatory B (Breg) cell populations $\mathrm{CD} 24^{\text {high }} \mathrm{CD} 27^{+}$and $\mathrm{CD} 25^{+} \mathrm{CD} 27^{+} \mathrm{B}$ cells in patients, particularly in those with active disease. We also observed the phenotypes of these different Breg cell populations to be different from the corresponding cells in HC. 
We hypothesize that the increased activation potential by neutrophils in AAV to produce ROS and undergo NETosis/necrosis contribute to the excessive inflammation as well as an increased antigen load of PR3 and MPO, and that this in combination with dysregulation of innate-like B cells and Breg cells could lead to break of tolerance to these antigens and production of pathogenic autoantibodies. ANCA can in turn activate neutrophils to release NETs, suggesting a vicious circle in disease development. 


\section{Sammanfattning}

Vaskulit är samlingsnamnet på en grupp av sjukdomar som karaktäriseras av

blodkärlsinflammation. Dessa sjukdomar delas upp baserat på vilken storlek kärlen har som drabbas; små, medelstora eller stora kärl. Den här avhandlingen är inriktad mot en grupp av vaskuliter som karaktäriseras av inflammation i små kärl, vilket gör att organ med många små kärl drabbas hårdast, som till exempel njurarna. Njurarna är involverade i hela $70 \% \mathrm{av}$ sjukdomsfallen och ofta rör det sig om en snabbt förlöpande njurskada som kan leda till kroniskt dialysbehov eller döden. Även lungorna drabbas ofta men hud, leder, ögon, tarmar och nerver kan också påverkas. Gemensamt för dessa sjukdomar är också att det finns antikroppar som är riktade mot proteiner på en vit blodcell av typen neutrofil (vita blodceller tillhör immunförsvaret). Antikroppar är molekyler som kroppen vanligtvis utvecklar mot främmande ämnen, exempelvis bakterier, och bidrar till eliminering av det de binder till. Vid dessa sjukdomar så är antikropparna riktade mot proteiner på neutrofiler och tros spela roll i sjukdomsutvecklingen genom att aktivera neutrofilerna. Detta betyder att kroppen angriper sig själv, något som kallas för autoimmun sjukdom. De här antikropparna heter antineutrofila cytoplasmiska antikroppar (ANCA) och sjukdomarna benämns därför kollektivt ANCA-associerad vaskulit.

Processen då immunförsvaret aktiveras vid en infektion eller andra skador kallas för inflammation. Neutrofiler spelar en central roll vid infektioner genom att ta död på mikroorganismer, vilket de gör genom att frisätta ämnen som till exempel reaktiva syreradikaler (ROS) och nätliknande strukturer som innehåller giftiga proteiner (NETs). Samtidigt som det finns en pågående inflammation finns också celler som bidrar till att begränsa denna så det inte urartar. Detta sker bland annat av andra vita blodceller som heter regulatoriska B- och T celler. Efter avvärjande av en mikroorganism så dämpas normalt en inflammation under milda omständigheter. Vid ANCA-associerad vaskulit däremot så kan man se att trasiga neutrofiler blir kvar i inflammationsområdet. Detta gör att fler vita blodceller som bidrar till inflammation rekryteras och man utvecklar en kronisk inflammation. Vi tror att de trasiga neutrofilerna man ser är neutrofiler som frisatt NETs som sedan blivit kvar. Normalt sett så ska dessa celler och NETs städas undan efter att de gjort sitt jobb med att avdöda främmande mikroorganismer. 
Vi tror att en överproduktion av NETs eller en otillräcklig bortrensning av dessa kan påverka den kärlinflammation man ser vid ANCA-associerad vaskulit. Det har visat sig att ANCA som kan aktivera neutrofiler kan få neutrofilerna att frisätta NETs. Detta skulle kunna vara en förklaring till att patienterna har extra mycket NETs i blodkärlen, eftersom patienterna har dessa ANCA.

En intressant aspekt med ANCA är att de faktiskt också finns hos friska personer, men då aktiverar de inte neutrofiler. Syftet med att friska personer har ANCA är att de hjälper till att städa undan proteiner som annars kan skada kroppen. Förutom att bakterier och andra mikroorganismer kan vara skadliga så är det många av kroppens egna ämnen som också är gifta om de inte städas undan av kroppens immunförsvar. De proteiner som ANCA binder till är desamma hos friska som det är hos sjuka, så något har gjort att ANCA blivit farliga hos patienterna. De proteiner som ANCA binder till finns förutom på neutrofilerna också $\mathrm{i}$ NETsen. Man tror att om NETsen får ligga och skräpa för länge så kan kroppen komma att börja göra farliga ANCA istället för de bra ANCA som försöker städa undan proteinerna (dvs. det blir en felreaktion hos ANCA). Det skulle kunna resultera i att farliga ANCA börjar aktivera neutrofiler, vilket leder till mer NETs och så får man en ond cirkel som leder till kronisk inflammation.

Huvudsyftet men denna avhandling var att studera faktorer (ROS och NETs) hos neutrofiler som tros bidra till att driva på den inflammationen man ser vid ANCA-associerad vaskulit men också att studera celler som tros vara viktiga att reglera inflammationsförloppet. Genom att göra detta hoppas vi att bättre kunna förstå sjukdomsförloppet. Det är nödvändigt för att i förlängningen kunna utveckla bättre läkemedel mot de patienter som idag lider av ANCAassocierad vaskulit. Framsteg kan också göra så att vi kan använda den behandling som finns tillgänglig idag på ett effektivare sätt. Ju mer vi lär oss om sjukdomen ju bättre kan vi anpassa behandlingen för olika patienter. 
Våra resultat visar att neutrofiler hos patienter med ANCA-associerad vaskulit i större utsträckning frisätter NETs och vi kunde också se att patienterna hade förhöjda nivåer av NETs i blodcirkulationen jämfört med friska personer. Vi kunde också se att neutrofiler från patienterna reagerade starkare (producerade mer ROS) än neutrofiler från friska personer när de aktiverades med samma farliga ANCA, vilket tyder på att neutrofiler från patienter är känsligare för aktivering. Dessa fynd indikerar tillsammans att patienterna har problem med reglering av hur mycket farliga ämnen som neutrofiler från patienter frisätter (NETs och ROS).

Som tidigare nämndes så finns det också bra ANCA, som istället för att aktivera neutrofiler skyddar kroppen genom att istället städa bort proteiner. De celler som frisätter dessa ANCA kallas för innate-liknande B-celler. Som tidigare nämndes så finns det också B celler som bidrar till att dämpa inflammation; de kallas regulatoriska B-celler. När vi undersökte nivåerna av dessa olika B-cellspopulationer så kunde vi se att patienterna hade lägre nivåer av både innate-liknande och vissa regulatoriska B-cellspopulationer.

Våra resultat pekar sammantaget på att patienternas neutrofiler är mer lättaktiverade än de hos friska personer till att frisätta ämnen som kan skada blodkärlen. Detta i kombination med att patienterna har färre celler som tros bidra till att dämpa inflammationsförlopp skulle kunna leda till den ökade inflammationen vid dessa sjukdomar. Eftersom dessa mekanismer tillsammans också tillåter NETs att ligga och skräpa så bidrar detta troligtvis till produktion av farliga ANCA vid dessa sjukdomar. 


\section{Table of Contents}

Original publications .......................................................................................................1

Supplemental relevant publication.....................................................................................................2

Abbreviations ..................................................................................................................................................

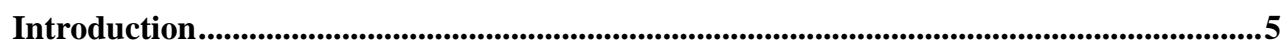

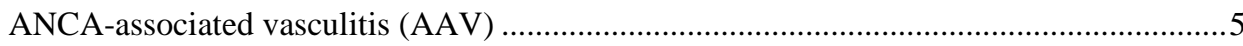

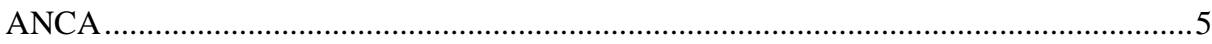

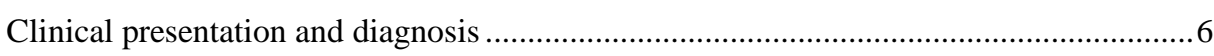

Assessment of disease activity .................................................................................

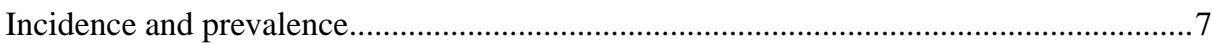

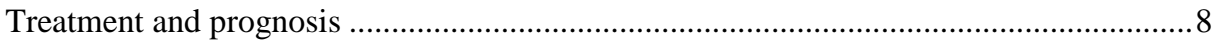

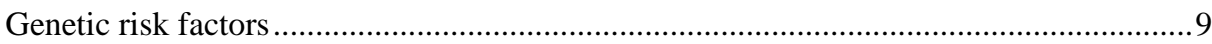

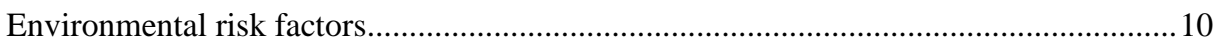

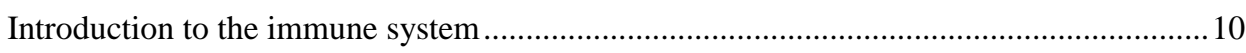

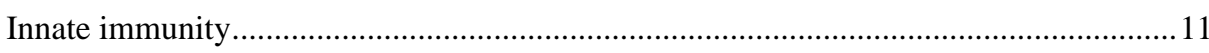

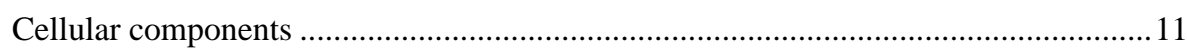

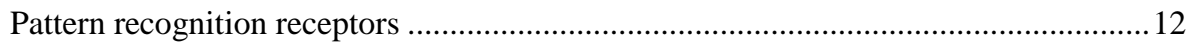

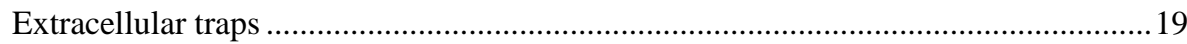

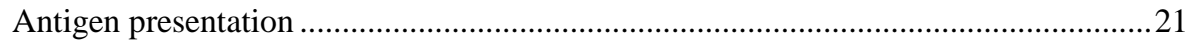

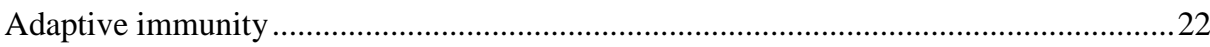

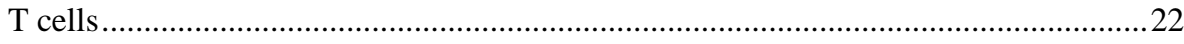

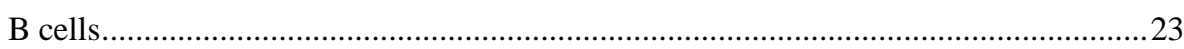

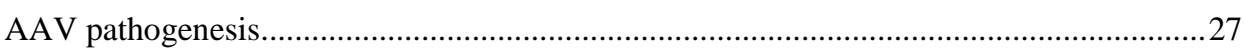

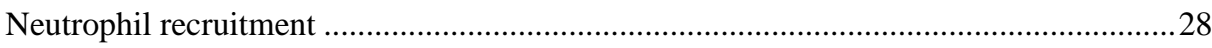

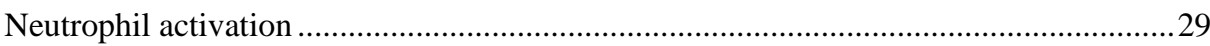

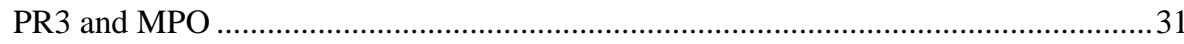

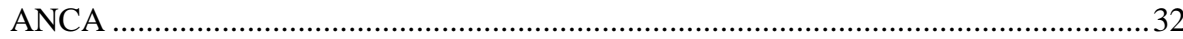

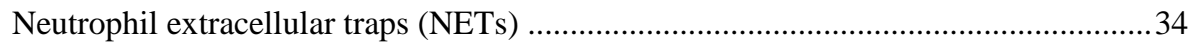

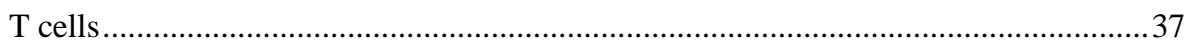

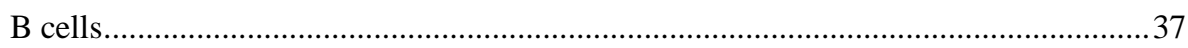

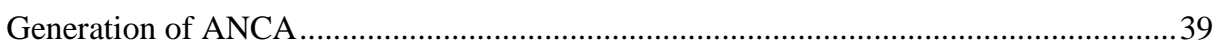

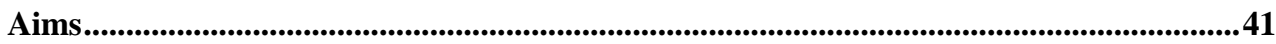

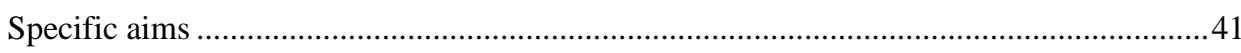




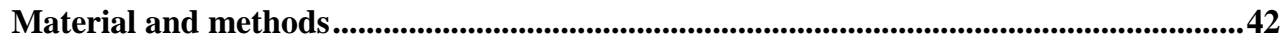

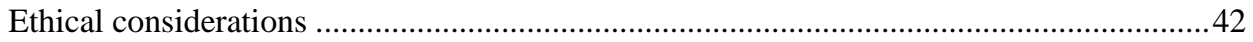

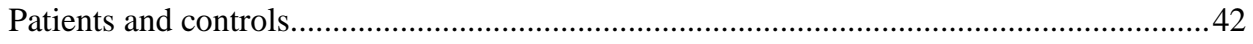

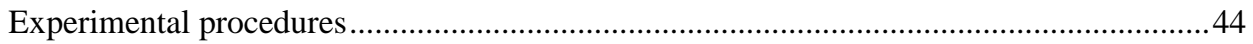

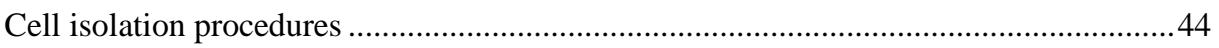

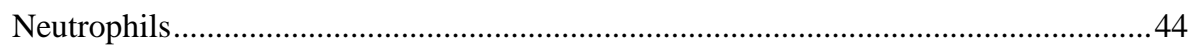

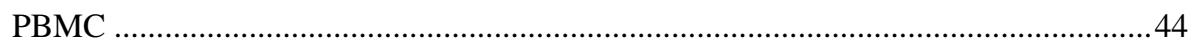

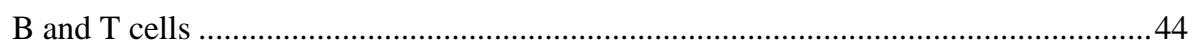

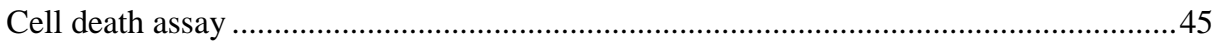

Immunofluorescence of NETs and live cell imaging of DNA webs ..............................47

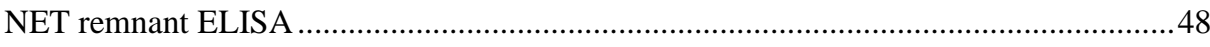

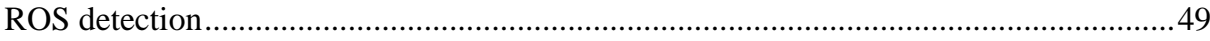

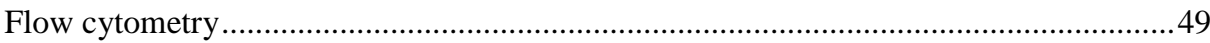

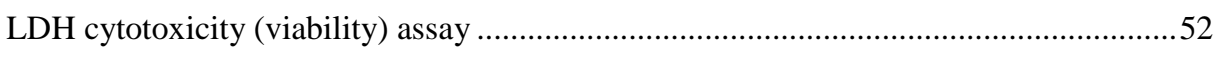

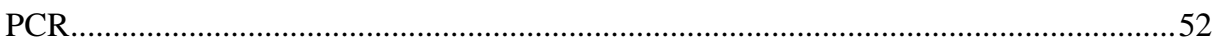

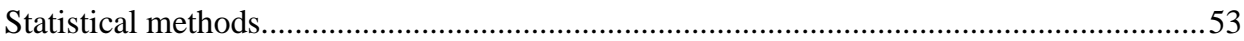

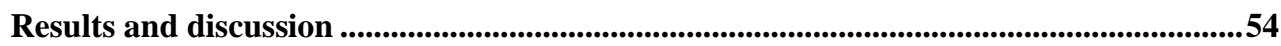

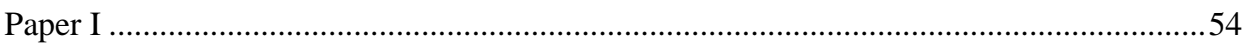

Increased levels of NET remnants in the circulation during active disease ......................54

Enhanced spontaneous NETosis/necrosis in patients ....................................................56

Inverse correlation between NET remnants and PR3-ANCA during remission ..............57

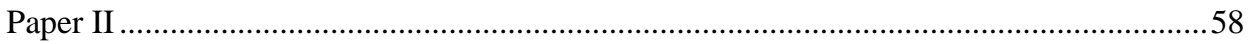

Neutrophils from patients are more easily activated by ANCA ....................................58

Affinity important for ANCA activation of neutrophils..................................................59

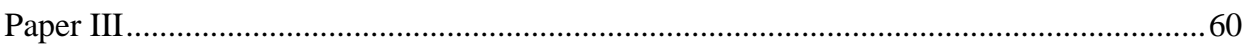

$\mathrm{B}$ and T cells can release mtDNA as ET-like structures (webs) .....................................60

mtDNA web release pathway does not induce ROS/RNS nor cell death..........................62

mtDNA web release operates in parallel with BCR, TLR9, STING and AIM2 signals ..63

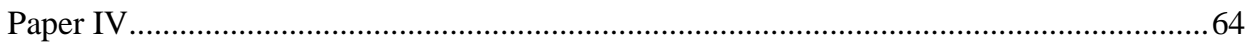

Reduced levels of innate-like B cells in the circulation of patients.................................64

Reduced levels and altered phenotypes of Breg cells in the circulation of patients.........67

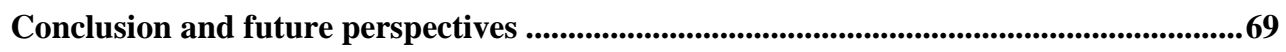

Acknowledgements ........................................................................................................................ 73

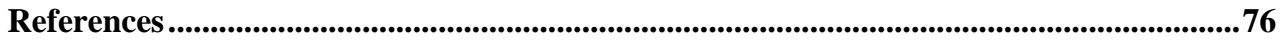




\section{Original publications}

I. Increased levels of neutrophil extracellular trap remnants in the circulation of patients with small vessel vasculitis, but an inverse correlation to anti-neutrophil cytoplasmic antibodies during remission.

Daniel Söderberg, Tino Kurz, Atbin Motamedi, Thomas Hellmark, Per Eriksson and Mårten Segelmark

Rheumatology, 2015, 54: 2085-2094

II. Neutrophils from vasculitis patients exhibit an increased propensity for activation by anti-neutrophil cytoplasmic antibodies

Susanne Ohlsson, Sophie Ohlsson, Daniel Söderberg, Lena Gunnarsson, Åsa Pettersson, Mårten Segelmark and Thomas Hellmark

Clin Exp Immunol, 2014, 176: 363-372

III. Web-casting lymphocytes: Immune sensing of GC-rich oligonucleotides induce release of mitochondrial DNA webs

Björn Ingelsson, Daniel Söderberg, Tobias Strid, Anita Söderberg, Ann-Charlotte Bergh, Vesa Loitto, Kourosh Lotfi, Mårten Segelmark, Giannis Spyrou, and Anders Rosén

Submitted

IV. Reduced levels of innate-like and regulatory $B$ cell populations in the circulation of patients with ANCA-associated vasculitis

Daniel Söderberg, Per Eriksson, Jan Ernerudh and Mårten Segelmark

Manuscript 


\section{Supplemental relevant publication}

SI. Neutrophil Extracellular Traps in ANCA-associated Vasculitis.

Daniel Söderberg and Mårten Segelmark

Front Immunol, 2016, 30; 7:256 


\section{Abbreviations}

AAV

ADCC

AIM1

ALRs

ANCA

APC

BCR

Breg cell

BVAS

CCL

$\mathrm{CD}$

$\mathrm{CHCC}$

CLR

Co1

CRP

CTL

CXCL

$\mathrm{Cyb}$

DAMP

DC

DPI

EGPA

ELISA

EMA

FACS

FBS

FcR

FPR1

FSC

FMO

GPA

GWAS

HLA

HMGB1

HOCL

IFN

IFI16

IDO

IFN- $\gamma$

$\mathrm{Ig}$

IL
ANCA-associated vasculitis

Antigen-dependent cell-mediated cytotoxicity

Absent in melanoma 1

AIM2-like receptors

Anti-neutrophil cytoplasmic antibody

Antigen presenting cell

B cell receptor

Regulatory B cell

Birmingham vasculitis activity score

C-C motif ligand

Cluster of differentiation

Chapel Hill Consensus Conference

C-type lectin receptor

Cytochrome oxidase c subunit 1

C-reactive protein

Cytotoxic T lymphocyte

$\mathrm{C}-\mathrm{X}-\mathrm{C}$ motif ligand

Cytochrome oxidase $b$

Damage associated molecule pattern

Dendritic cell

Diphenyleneiodonium

Eosinophilic granulomatosis with polyangiitis

Enzyme-linked immunosorbent assay

European Medicines Agency

Fluorescence activated cell sorting

Foetal bovine serum

Fc receptor

Formyl peptide receptor 1

Forward scatter

Fluorochrome minus one

Granulomatosis with polyangiitis

Genome-wide association study

Human leukocyte antigen

High-mobility group box 1

Hypochlorous acid

Interferon

Interferon gamma inducible protein 16

Indoleamine 2,3-dioxygenase

Interferon- $\gamma$

Immunoglobulin

Interleukin 


\begin{tabular}{|c|c|}
\hline LDG & Low-density granulocyte \\
\hline $\mathrm{LDH}$ & Lactate dehydrogenase \\
\hline MAC & Membrane attack complex \\
\hline MACS & Magnetic activated cell sorting \\
\hline MAPK & Mitogen-activated protein kinase \\
\hline MBL & Mannose binding lectin \\
\hline MCP-1 & Monocyte chemoattractant protein 1 \\
\hline $\mathrm{mDC}$ & Myeloid DC \\
\hline MPA & Microscopic polyangiitis \\
\hline MPO & Myeloperoxidase \\
\hline mtDNA & Mitochondrial DNA \\
\hline $\mathrm{MZ}$ & Marginal zone \\
\hline NADPH & Nikotinamid-adenin-dinukleotidfosfat \\
\hline $\mathrm{Nd} 1$ & NADH dehydrogenase subunit 1 \\
\hline $\mathrm{NE}$ & Neutrophil elastase \\
\hline NET & Neutrophil extracellular trap \\
\hline NK cell & Natural killer cell \\
\hline NLR & NOD-like receptor \\
\hline PAMP & Pathogen associated molecule pattern \\
\hline PBMC & Peripheral blood mononuclear cell \\
\hline PCR & Polymerase chain reaction \\
\hline PMT & Photomultiplier tube \\
\hline PR3 & Proteinase 3 \\
\hline PRR & Pattern recognition receptor \\
\hline PTU & Propylthiouracil \\
\hline PTX3 & Pentraxin 3 \\
\hline RA & Rheumatoid arthritis \\
\hline RBL & Rat basophilic leukaemia \\
\hline RLR & Retinoic acid-inducible gene I-like receptor \\
\hline ROS & reactive oxygen species \\
\hline RPMI & Rosewell park memorial institute \\
\hline SLE & Systemic lupus erythematous \\
\hline SR & Scavenger receptor \\
\hline SSC & Side scatter \\
\hline TCR & $\mathrm{T}$ cell receptor \\
\hline TD & $\mathrm{T}$ cell dependent \\
\hline Tfh & Follicular T helper cell \\
\hline TGF $\beta$ & Transforming growth factor beta \\
\hline Th & Helper T cell \\
\hline TI & $\mathrm{T}$ cell independent \\
\hline TLR & Toll-like receptor \\
\hline Treg cell & Regulatory T cell \\
\hline
\end{tabular}




\section{Introduction}

\section{ANCA-associated vasculitis (AAV)}

Vasculitis means blood vessel inflammation, but is also the designation for a group of inflammatory diseases. Vasculitis may develop secondary to rheumatic disease, malignancy or infection, whereas if the cause is unknown it is called primary vasculitis. Any organ in the body can be affected, and vasculitides are categorized based on the vessel size predominantly being affected; small, medium or large vessels (Jennette and Falk 1997). Vasculitides affecting small vessels are divided into those associated with immune complex depositions (i.e. antibodies that bind to antigens and get trapped in vessel walls) and those without such depositions. This thesis focuses on this second subgroup of primary small vessel vasculitides characterized by pauci-immune inflammation and the presence of anti-neutrophil cytoplasmic antibodies (ANCA) in the circulation, which collectively is referred to as ANCA-associated vasculitis (AAV). AAV comprise three different diseases; granulomatosis with polyangiitis (GPA, earlier named Wegener's granulomatosis (Falk et al. 2011)), microscopic polyangiitis (MPA), and eosinophilic granulomatosis with polyangiitis (EGPA, earlier named ChurgStrauss Syndrome (CSS)) (Gadola and Gross 2012).

\section{$A N C A$}

ANCA can in addition to AAV sometimes also be detected in anti-GBM disease but are uncommon in other forms of vasculitis. ANCA can also occur in other systemic inflammatory diseases (systemic lupus erythematous (SLE), Sjögrens syndrome and rheumatoid arthritis (RA)) as well as in the inflammatory bowel disease ulcerative colitis, and primary sclerosis cholangitis. ANCA can also be observed in various infectious diseases (caused by bacteria, virus and amoeba), hematopoietic malignancies, and can be induced by certain drugs (Weiner and Segelmark 2016). 
ANCA are directed against proteins normally present in cytoplasmic granules of neutrophils, and in AAV these are primarily proteinase 3 (PR3) and myeloperoxidase (MPO) (Jennette and Falk 1997). PR3-ANCA are primarily observed in patients with GPA (70-80\% of the patients), whereas MPO-ANCA are mainly present in patients with MPA (50-70\%). In EGPA, MPO-ANCA is more common (30-40\%) than PR3-ANCA (15-20\%). However, in all three diseases some patients are ANCA-negative (Wiik 2009).

\section{Clinical presentation and diagnosis}

Before diagnosis, general symptoms such as fever, weight loss, arthralgia, night sweats and malaise are often experienced. To make a correct diagnosis, measurement of ANCA and examination of biopsies are vital (Hoffman 2012). GPA and EGPA are characterized by necrotizing granulomatous inflammation in biopsies of the lower respiratory tract, and GPA also often exhibit such inflammation in the upper respiratory tract (Jennette and Falk 1997, Hoffman 2012). Nasal disease can display symptoms such as obstruction, crustings, ulcers and cartilage destruction, whereas otitis (middle ear inflammation) and subglottic stenosis (airway narrowing) are examples of other upper respiratory manifestations (Hoffman 2012). EGPA is distinguished from GPA by elevated levels of eosinophils in the blood (eosinophilia) and asthma. MPA can be differentiated from both GPA and EGPA by the absence of granulomatous inflammation and asthma. All three diseases also affect the skin, joints, eyes, and nerves to various extents. Renal involvement, including haematuria (with or without proteinuria and affected glomerular filtration rate), is present in most patients with MPA (90\%), compared to 50-80\% in GPA and 45\% in EGPA (Jennette and Falk 1997, Mohammad et al. 2009). Histology shows pauci-immune necrotizing glomerulonephritis with fibrinoid necrosis, extra-capillary proliferation, cellular crescents and influx of neutrophils. More chronic changes including fibrous crescents or totally sclerosed glomeruli can be observed upon disease progression (Hoffman 2012). In addition AAV patients with active disease also possess an increased risk for venous thromboembolism (Stassen et al. 2008, Allenbach et al. 2009). 
The nomenclature for vasculitides are updated continuously, and the most recent update is the Chapel Hill Consensus Conference (CHCC) definitions from 2012. This system is solely a nomenclature system and is not intended to be used for classification or diagnostic purposes (Jennette et al. 2013). There is, however, a system developed for how the CHCC definitions can be used for classification and diagnosis. This system was developed in 2007 and was primarily intended for epidemiological studies; it is referred to as the European Medicines Agency (EMA) algorithm (Watts et al. 2007). An evaluation of this algorithm was recently performed due to the updated CHCC definitions in 2012, but it was shown that the updated nomenclature did not alter the performance of the EMA algorithm to classify the different AAV disease entities (Abdulkader et al. 2013).

\section{Assessment of disease activity}

To determine disease activity in patients diagnosed with AAV, a system called Birmingham vasculitis activity score (BVAS) is employed. This system combines clinical manifestations from nine different organ systems (Luqmani 2015).

\section{Incidence and prevalence}

The annual incidence for AAV varies geographically and between ethnic groups, suggesting a genetic component in these diseases. GPA and PR3-ANCA appear to be more common in Europe and Caucasians whereas MPA and MPO-ANCA are more common in for example Japan (Watts et al. 2015). A study in Sweden reported an annual incidence for GPA and MPA of around 10 per million and for EGPA of 0.9 per million. The incidence was shown to increases with age, with a peak incidence in those over 75 years (Mohammad et al. 2009). The same group has also reported a point prevalence of 160 per million for GPA, 94 for MPA and 14 for EGPA for the same area in Sweden (Mohammad et al. 2007). The median age at diagnosis was reported to be 55.5 years for GPA, 60 for MPA and 53.5 for EGPA (Mohammad et al. 2007). The gender distribution was shown to be fairly similar within the disease entities, although GPA was reported to be more common in men in one of the studies (Mohammad et al. 2009). 


\section{Treatment and prognosis}

The mortality rate in AAV without treatment is very high, around $80 \%$ at one year according to early reports (Hilhorst et al. 2013). The introduction of immunosuppressive treatment with Cyclophosphamide (a cytotoxic drug) in combination with glucocorticoids, led to a drastic improvement in survival. Today, a biological drug called rituximab that deplete B cells is also being used in combination with glucocorticoids to induce remission (Yates et al. 2016). These two strategies to induce remission is what's currently recommended for organthreatening or life-threatening AAV, whereas a combination of glucocorticoids in combination with methotrexate or mycophenolate mofetil is recommended in non-organ threatening AAV (Yates et al. 2016). This stage of treatment is referred to as induction therapy and is applied at disease onset or in the case of relapses. Once patients achieve remission, treatment is focused on remaining in the inactive phase by dampening the immune response and is referred to as maintenance therapy. The recommendations at this stage are to use low doses of glucocorticoids in combination with drugs less toxic than cyclophosphamide such as azathioprine, rituximab, methotrexate or mycophenolate mofetil, for at least two ears (Yates et al. 2016).

A problem in AAV is that about $40-55 \%$ of the patients in remission relapse into an active state, and that the mortality rate still is about 25\% within five years (Flossmann 2015). ANCA are important for diagnosis, but do only modestly assist in the prediction of relapses, although better in patients with renal involvement (Tomasson et al. 2012, Kemna et al. 2015). Thus, there is a demand for better predictors of relapse, and research to identify novel biomarkers to monitor disease activity is crucially needed. 


\section{Genetic risk factors}

As already described, AAV differ between ethnic groups, indicating a genetic component for these diseases. Various case reports, as well as a larger study using Swedish nationwide registers, imply an increased risk for first-degree relatives to develop disease (Muniain et al. 1986, Hay et al. 1991, Sewell and Hamilton 1992, Manganelli et al. 2003, Knight et al. 2008, Gomes et al. 2009, Prendecki et al. 2016).

Recently, two genome-wide association studies (GWAS) were conducted in search for genetic factors connected to AAV. In one study, it was shown that GPA/PR3-ANCA was connected to HLA-DP, SERPINA1 (encoding $\alpha 1$-antitrypsin) and PRTN3 (encoding PR3) whereas MPA/MPO-ANCA associated with HLA-DQ. Notably, it was shown that these genetic alterations showed a stronger association with PR3-ANCA and MPO-ANCA than with the clinical phenotypes GPA and MPA, respectively (Lyons et al. 2012). This has led to discussions that perhaps GPA and MPA should be re-classified as PR3-ANCA and MPOANCA vasculitis. The second GWAS, which only included GPA patients, also observed an association with HLA-DP in GPA, but they also found a genetic alteration in the gene SEMA6A (encoding Semaphorin 6A) in these patients (Xie et al. 2013).

Previous smaller genetic studies have shown alterations for AAV patients also in the genes PTPN22 (also reported in other autoimmune diseases), C3 (central component in the complement system), the IL 2 receptor (or CD25, expressed on activated cells and important for B and T cell survival), FcR (involved in phagocytosis and binds antibodies such as ANCA), CTLA4 (contact-inhibition of immunological responses) and IL-10 (antiinflammatory cytokine that dampens immunological responses) (Persson et al. 1999, Willcocks et al. 2010, Persson et al. 2013). These genes did not reach statistical significance in the two GWAS studies but could still be important in AAV. This was also highlighted in a recent meta-analysis that showed some of these genes, but also for example HLA and SERPINA1 as described above, to be associated with AAV. This study also confirmed that subdivision of AAV by ANCA serotype rather than clinical phenotype has stronger genetic basis (Rahmattulla et al. 2016). 


\section{Environmental risk factors}

Several studies have suggested an association for AAV with silica exposure, similar to other autoimmune diseases, and such an association could be confirmed in a recent meta-analysis (Gomez-Puerta et al. 2013). Infections have for long been hypothesized to be implicated in the aetiology of AAV and as a triggers of relapses. The explanations have primarily focused on molecular mimicry, either directly (Kain et al. 2008) or indirectly through autoantigen complementarity (Pendergraft et al. 2004). It has also been shown that AAV can be induced by various drugs, for example by the thyroid drug propylthiouracil (PTU). Over $20 \%$ of patients with Graves' disease treated with PTU develop MPO-ANCA and some of them also an AAV-like disease (Wada et al. 2002, Balavoine et al. 2015).

\section{Introduction to the immune system}

Our body's first line of defence against foreign invaders is the epithelia of the skin and the gastrointestinal, respiratory, and urogenital tracts. Epithelial cells constitute a physical barrier but can also produce antimicrobial substances. Bacteria of the normal flora are present on most epithelial surfaces and contribute to a protective environment by competing with foreign microorganisms for nutrients and space, as well as by producing antimicrobial substances (Murphy et al. 2008, Abbas et al. 2012).

The immune system is traditionally divided into innate and adaptive immunity (Abbas et al. 2012). If a microorganism breaches the epithelial barrier, innate immunity mediates the initial protection. In addition to respond to infectious agents, innate immunity also recognizes and aids in clearance of host molecules upon cellular/and or tissue damage to maintain homeostasis. Innate immunity relies on germ-line encoded (pre-programmed) recognition molecules providing a fast response towards a limited set of evolutionary conserved structures, foreign or self. This is in contrast to adaptive immunity that upon exposure to a microorganism provides a slower but highly specific immunological response. Adaptive immunity also develops a memory towards the specific microorganism to be able to elicit a fast and effective response upon future exposure. Thus, through life each individual develops their own unique (acquired) adaptive immunity. 


\section{Innate immunity}

\section{Cellular components}

Cells of innate immunity include macrophages, dendritic cells (DCs), granulocytes (neutrophils, mast cells, eosinophils and basophils), natural killer (NK) cells as well as innate-like T and B cells (Abbas et al. 2012). B1 and marginal zone (MZ) B cells that are considered to be innate-like cells are presented in more detail in the section on B cells.

Tissues macrophages and DCs are located in peripheral tissues and constantly scan those areas for invading microbes. Upon encountering microbes, they can both exert phagocytosis ("eating", which is the major mechanism to remove pathogens, cells and debris) as well as alert other immune cells. Different responses are mounted depending on the pathogen; inflammatory (bacteria and fungi) or anti-viral (viruses). Monocytes (which differentiate into macrophages when activated) and neutrophils are recruited to the inflammatory site and activated during inflammatory responses and NK cells during anti-viral responses. Neutrophils are introduced in more detail in the section of the pathogenesis of AAV. Macrophages and DCs, as well as B cells, are antigen presenting cells (APCs), meaning that they present cellular products from phagocytised pathogens to T cells, which initiates and shapes the adaptive immune response (outlined in more detail later). Although DCs and macrophages share several mechanisms, DCs are the principle APC and macrophages the most important phagocyte. Macrophages play an important role also during resolution of inflammation in phagocytosis of apoptotic cells of the host, which otherwise could lead to secondary necrosis that can cause inflammation. Eosinophils, basophils and mast cells are also involved in inflammatory responses but connected to parasite infections (such as helminths) and allergic reactions, and are activated by parasitic ligands or allergens (Serhan et al. 2010). 


\section{Pattern recognition receptors}

Innate immunity is equipped with a set of pattern recognition receptors (PRRs) that can identify structures both associated with microbes (pathogen associated molecule patterns (PAMPs)) and with host cell material (damage associated molecule patterns (DAMPs)) (Abbas et al. 2012). The receptors are either expressed by cells or present as soluble recognition molecules in fluids. PAMPs are expressed on microbes such as bacteria, fungi and virus and protozoa (Akira et al. 2006), whereas DAMPs are expressed on or released from host cells upon cellular damage or cell death and include for example heat shock proteins, ATP, nuclear and mitochondrial DNA, uric acid and high-mobility group box 1 (HMGB1) (Kono and Rock 2008, Nakahira et al. 2015). Recognition of PAMPs and DAMPs initiates an immune response facilitating the clearance of those molecules. Recognition of DAMPs is a constantly ongoing process to maintain homeostasis, and dysfunctional recognition and/or insufficient clearance of DAMPs are connected to autoimmunity and other inflammatory conditions (Jounai et al. 2012, Senovilla et al. 2013).

\section{Cellular recognition molecules}

The repertoire of cellular PRRs can broadly be divided into toll-like receptors (TLRs), NODlike receptors (NLRs), C-type lectin receptors (CLRs), retinoic acid-inducible gene I-like receptors (RLRs), AIM2-like receptors (ALRs) and scavenger receptors (SRs) (Kawai and Akira 2009, Osorio and Reis e Sousa 2011, Canton et al. 2013, O'Neill et al. 2013, Paludan and Bowie 2013, Brubaker et al. 2015). The receptors are found to various extents on the cell surface membrane (TLRs, CLRs and SRs), on endosomes (TLRs) (for endocytosed material) or in the cytosol (NLRs, RLRs and ALRs) (Abbas et al. 2012), of different immune cells as well as epithelial and endothelial cells. An additional important PRR is formyl peptide receptor 1 (FPR1) expressed on neutrophils that sense $\mathrm{N}$-formyl peptides released from bacteria and mitochondria, which aid in chemotaxis and activation of neutrophils (Mantovani et al. 2011). Binding of PRRs to their ligands initiates activation of downstream signalling with activation of the transcription factor NF-kB, MAPKs and/or inflammasomes and most often results in production of inflammatory mediators such as interleukin (IL)-1 $\beta$, IL-6, tumour necrosis factor (TNF), C-X-C motif ligand (CXCL) 8 (IL-8) and C-C motif ligand 2 (CCL2) (macrophage chemoattractant protein-1 (MCP-1)) that in turn modulate the immune response. 


\section{Toll-like receptors (TLRS)}

The best known PRR family is that of the TLRs and twelve different receptors have been described in mammals. TLR 1, 2, 4, 5, 6, and 11 (TLR 11 in mice only) are expressed on the cell surface. Heterodimers of TLR2/TLR1 or TLR2/TLR6 recognize bacterial lipopeptides, TLR4 binds to LPS (bacteria), mannan (fungi), envelope proteins (virus) and glycoinositolphopholipids (parasites) whereas TLR5 detects flagellin (bacteria) and TLR11 an unknown motif on uropathogenic bacteria. TLR3, 7-8, 9 and 13 (TLR 13 in mice only) are localized to endosomes within the cell and sense double stranded ribonucleic acid (RNA) (virus), single stranded RNA (virus), CpG deoxyribonucleic acid (DNA) (bacteria and virus) and ribosomal RNA (bacteria), respectively (Akira et al. 2006, O'Neill et al. 2013). TLR4 and TLR7-9 have been shown to also recognize DAMPs such as heat shock proteins and nucleic acids, respectively (Akira et al. 2006, O'Neill et al. 2013). There has been some controversy whether TLR9 also is expressed on the cell surface but recent research postulates that it indeed is, although it was also reported that its binding properties are altered (Guerrier et al. 2014). Downstream signalling of all TLRs leads to the activation of transcription factor NF$\kappa \mathrm{B}$ and various mitogen-activated protein kinases (MAPKs) (O'Neill et al. 2013). NF-kB promotes production of the proinflammatory cytokines TNF, IL-6, proIL-1 $\beta$, proIL18 and IL-12, whereas MAPKs affect other transcription factors such as AP-1 and CREB that are involved in production of the proinflammatory cytokine IL-23 and the anti-inflammatory cytokine IL-10, respectively (Saraiva and O'Garra 2010, Mills 2011, O'Neill et al. 2013). The endosomal TLRs (as well as TLR4 if endocytosed) can in addition to activate the above transcription factors also activate the transcription factor interferon regulatory factor (IRF), leading to production of type I interferons (IFNs), which is important for anti-viral responses (O'Neill et al. 2013). TLR activation also causes the release of chemokines that recruit immune cells to inflammatory sites. 


\section{C-type lectin receptors (CLRs)}

CLRs can detect most classes of pathogens through recognition of mannose (virus, fungi, and mycobacteria), fucose (bacteria and helminths) and glycan (mycobacteria and fungi). The mannose receptor (CD206), DEC205 and DC-SIGN share a very important feature in that they are involved in internalization and degradation of pathogens for subsequent antigen presentation on major histocompatibility complex (MHC) II. In addition to this, CLRs consists of receptors that can either directly promote proinflammatory responses or be involved in modulating responses by other PRRs, resulting in either proinflammatory or regulatory responses. Direct proinflammatory responses are mediated via receptors such as Dectin1, Dectin2 and MINCLE. Dectin1 for example that recognizes beta-glucan is particularly important during fungal infections. CLRs can, however, also regulate immune responses by interfering with signals from TLRs, such as inhibit TLR4-induced IL-12 production and TLR9-induced type I IFN, TNF and IL6 production, or increase TLR9induced IL-10 production (Geijtenbeek and Gringhuis 2009).

\section{Scavenger receptors (SRs)}

Another group of membrane bound receptors is the SRs, of which CD36, SR-A1 and CD163 are a few examples. The main functions of these receptors are to recognize and initiate phagocytosis ("scavenging") of dead cells and microbes, which is achieved by their great diversity in ligand recognition. The increased expression of SRs on M2 (anti-inflammatory) macrophages as compared to M1 (pro-inflammatory) macrophages promotes their ability for resolution of inflammation and in maintaining homeostasis (Canton et al. 2013).

\section{NOD-like receptors (NLRS)}

Intracellular located PPRs, such as NLRs are important for the recognition of bacterial motifs as well as DAMPs. An important feature restricted to NLRs is that they upon activation can form protein complexes called inflammasomes, which through caspase 1 cleaves proIL-1 $\beta$ and proIL-18 to their active forms (Guo et al. 2015). NLRP3 is the most well-known inflammasome. Activation of this inflammasome requires two signals; first via NF-kB that results in production of proIL-1 $\beta$ and proIL-18 as well as the protein NLRP3. This can be considered as “priming” (Philpott et al. 2014). 
The second signal can be stimuli associated to both PAMPs and/or DAMPs, such as ATP, pore-forming toxins, crystalline substances, nucleic acids, and fungal, bacterial or viral pathogens and results in formation of the NLRP3 inflammasome that in turn cleaves the cytokines (Guo et al. 2015). Important non-inflammasome forming NLRs are NOD1 and NOD2 that reacts to the bacterial peptidoglycans diaminopimelic acid and muramyldipeptide with production of proinflammatory cytokines and chemokines (Philpott et al. 2014).

AIM-2 like receptors (ALRs) and Rig-I-like receptors (RLRS)

In addition to TLR9 and NLRP3 that can detect DNA, a group of important cytoplasmic DNA sensors are the ALRs, which include absent in melanoma 2 (AIM2) and interferon gamma inducible protein 16 (IFI16). Upon DNA recognition, AIM2 forms the AIM2inflammasome that cleaves proIL-1 $\beta$ and proIL-18. However, DNA recognition by IFI16 induces stimulator of interferon genes (STING)-dependent type I IFN production (Paludan and Bowie 2013). There is also a family of RNA sensors; the RLRs. This family consists of the three members RIG-1, MDA5 and LGP2 and recognizes RNA viruses. The activation of RLRs results in production of inflammatory cytokines and IFNs. In addition to playing an important role in DNA signalling, STING is also involved in RIG-1 signalling as cells that lack STING possess a lower IFN response upon RNA viral activation. This is in contrast to TLR stimulation of RNA viruses where STING deficiency did not alter the anti-viral response (Kawai and Akira 2009).

To summarize, the different PRRs complement each other well as they are directed against different structures; microbial surface structures, DNA and RNA, with different responses depending on virus (type I IFNs) or other microbes (proinflammatory cytokines and formation of inflammasomes to activate IL-1 $\beta$ and IL-18). Several PPRs will be activated simultaneously during infections and complex scenarios emerge, as described above. PPRs within a family or between different PPR families often cooperate in a synergistic manner to provide a stronger reaction but can also regulate each other's responses (Trinchieri and Sher 2007, Philpott et al. 2014). 


\section{Soluble recognition molecules}

PAMPS and DAMPs can also be recognized by soluble molecules such as those of the complement system, members of the pentraxin family and antibodies.

\section{Complement system}

The complement system is a powerful tool in direct killing of bacteria, but also by providing products involved in opsonization of bacteria and apoptotic cells (resulting in phagocytosis) and in promoting chemotaxis and activation of immune cells (Merle et al. 2015a, Merle et al. 2015b). Three different pathways (alternative, lectin and classical pathway) can activate the complement cascade, and all three pathways results in clevage of the plasma protein $\mathrm{C} 3$ into the fragments C3a and C3b. This is achieved via C3 convertases (Serhan et al. 2010) (Fig. 1). $\mathrm{C} 3 \mathrm{~b}$ attaches to the surface of microbes where the complement cascade continues, and results in formation of a protein complex called membrane attack complex (MAC). MAC forms a pore in the bacterial cell wall, leading to cell lysis and direct killing. C3b can also bind to apoptotic cells, so that phagocytes with receptors for $\mathrm{C} 3 \mathrm{~b}$ can engulf these cells. The fragment $\mathrm{C} 3$ a released during the complement cascade is important for activation of mast cells to relase histamine to increase the vasopermeability at the site of inflammation, whereas both C3a and C5a and aid in chemotaxis and activation of neutrophils (Serhan et al. 2010, Phillipson and Kubes 2011).

The classical pathway is initiated upon activation of the complement component $\mathrm{C} 1 \mathrm{q}$ when binding to antibodies (IgG or IgM) or pentraxins (such as pentraxin 3 (PTX3) or C-reactive protein (CRP)) bound to microbes, or directly to LPS on bacteria. C1q can also bind to apoptotic cells, and facilitate phagocytosis via interaction with the C1q receptor on phagocytes. The lectin pathway is initiated by mannose binding lectin (MBL) (a soluble CLR) and ficolins upon binding to mannose-related carbohydrates on microbes. The alternative pathway shows a constant low activity in healthy individuals via spontaneous hydrolysis of $\mathrm{C} 3$, which results in a fluid $\mathrm{C} 3$ convertase. As generation of $\mathrm{C} 3 \mathrm{~b}$ by the $\mathrm{C} 3$ convertase in this pathway takes place in the fluids it does not allow $\mathrm{C} 3 \mathrm{~b}$ to bind to cell surfaces as during the other complement pathways. However, properdin, which can bind both to bacteria and damaged cells, can act as an initiator of the alternative pathway by recruiting the $\mathrm{C} 3$ convertase to cellular surfaces (Merle et al. 2015a, Merle et al. 2015b). 


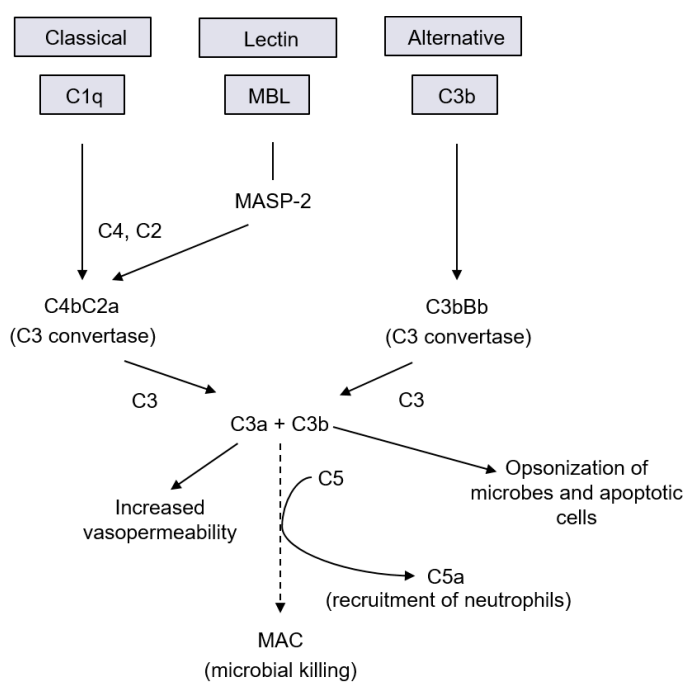

Figure 1. The complement cascade. The complement cascade can be initiated via three different pathways; classical, lectin and alternative (Serhan et al. 2010). All three pathways result in cleavage of the plasma protein $\mathrm{C} 3$ with formation of $\mathrm{C} 3 \mathrm{a}$ and $\mathrm{C} 3 \mathrm{~b}$. C3b binds to microbial cell surfaces where the complement cascade continues, resulting in formation of the MAC complex and microbial killing. C3a and C5a released during the complement cascade are involved in inflammatory responses. C3b can also bind to microbes and host cells and facilitate phagocytosis of these cells via opsonization.

\section{Pentraxins}

The pentraxin family consists of several members, where two well-known and important examples in humans are the acute phase protein CRP and PTX3. CRP is released from hepatocytes in response to IL-6 alone or in synergy with IL-1 $\beta$. CRP binds to bacteria, fungi, yeast and apoptotic cells and promote phagocytosis of these by interacting with Fc receptors (FcRs) on phagocytes. After binding to a microbe, CRP can also activate the complement system via C1q (classical pathway) and ficolins (lectin pathway) or regulate the alternative pathway by recruiting an inhibitor for this pathway (Factor H) (Moalli et al. 2011). PTX3 is produced by DCs and macrophages in response to cytokines such as IL-1 $\beta$ and TNF and by TLR activation. PTX3 is also stored in granulae of neutrophils and is released upon TLR activation. Similar to CRP, PTX3 promotes phagocytosis via FcRs and can also act via all three pathways of the complement system. However, in contrast to CRP, PTX3 shows a dual role for the classical complement activation pathway as PTX3 in the absence of microbes instead bind to and interfere with C1q, as a regulatory feature (Moalli et al. 2011). 


\section{Antibodies - focus on natural antibodies}

Immunoglobulins (Ig) (antibodies) are expressed and produced to promote clearance of both foreign and self-antigens. Antbodies are built up by two heavy $(\mathrm{H})$ chains and two light $(\mathrm{L})$ chains. Each chain contain a variable region and a constant region. Antibodies that contain different heavy chains belong to different classes, $\operatorname{IgM}, \operatorname{IgD}, \operatorname{IgG}, \operatorname{Ig} \mathrm{A}$ and $\operatorname{IgE}$. Antibodies can be divided into Fab and Fc parts, where the Fab includes the antigen recognition site and the Fc part interacts with FcRs on phagocyting cells. The different antibody classes differ in their effector functions but together promote clearance of antigens through phagocytosis via their Fc part, activation of the complement system via C1q, neutralisation and antigendependent cell-mediated cytotoxcicity (ADCC) resulting in killing of antibody coated cells (Schroeder and Cavacini 2010). During B cell developmet B cells can class-switch between different heavy chains. Most immunoglobulins of $\operatorname{IgA}$, IgE, IgG isotype, as well as subclasses of $\operatorname{IgG}(\mathrm{IgG1}, \mathrm{IgG} 3$ and IgG4) depends on B and T cell interactions, which is needed to generate antibodies with high affinity towards a specific antigen (Vidarsson et al. 2014).

Although antibody production is most often associated with adaptive immunity and high affinity antibodies for a specific antigen (described more later), it appears that there is also a pool of continuously produced antibodies with restricted antibody repertoire that targets both conserved microbial motifs as well as self-antigens. These are called natural antibodies, and are of low affinity and often of IgM class, but can also be of IgA and IgG class (Panda and Ding 2015). Natural antibodies are considered to be part of innate immunity, and play an important role in the early defense towards pathogens as well as in maintaining homeostasis through clearance of apoptotic cells and debris. This pool of antibodies emerges in the absence of exposure to foreign antigen challenge (i.e. spontaneously) or during exposure to $\mathrm{T}$ cell independent (TI) antigens and is produced by B1 and MZ B cells (described more thoroughly in the B cell section) (Baumgarth 2011, Cerutti et al. 2013). Natural antibodies can bind to nucleic acids, phospholipids and carbohydrates on microbes and to phospholipids on apoptotic cells, and aid in clearance of these by initiating the classical complement pathway (via C1q) and by promoting phagocytosis. Natural antibodies can also bind to for example oxidized low-density lipoprotein, collagen and neutrophil cytoplasmic enzymes and also here aid in clearance through phagocytosis (Ehrenstein and Notley 2010). 


\section{Extracellular traps}

A recent cellular mechanism described for the majority of the cells within the innate immune system is the capacity to release extracellular traps (ETs). ETs were first described in neutrophils by Brinkmann and colleagues 2004, as a mean to trap and kill bacteria (Brinkmann et al. 2004). The release of neutrophil extracellular traps (NETs) was found to be associated with a novel cell death mechanisms referred to as NETosis (or suicidal NETosis) (Fuchs et al. 2007, Steinberg and Grinstein 2007). It was later shown that NETs also can kill fungi and protozoa (Urban et al. 2006, Guimaraes-Costa et al. 2009). The killing capability of NETs in vitro has, however, also been questioned (Menegazzi et al. 2012), and it is indeed hard to elucidate its importance in vivo in this regard. Nevertheless, NETs can also be protective by alter virulence factors of bacteria when not killing them (Brinkmann et al. 2004). It has also been shown that virus can induce release of NETs via TLR4 as well as TLR7 and TLR8 and that NETs in turn can immobilize virus and alter their transcription (Schönrich and Raftery 2016). Both complement factors (such as properdin of the alternative complement pathway) (Wang et al. 2015) and PTX3 can also be found in the NETs (Jaillon et al. 2007).

NETosis depends on NADPH oxidase and reactive oxygen species (ROS) production as well as on autophagy and histone citrullination. Peptidyl arginine deiminase 4, neutrophil elastase (NE), and MPO is important in this signalling pathway $(18,22,23)$, and NETosis involve chromatin decondensation, nuclear envelope disintegration and mixing of chromatin with granular proteins before plasma membrane rupture and NET-release (Fuchs et al. 2007). About 20 different proteins have been identified in NETs, including various proteins with proinflammatory characteristics, such as histones, HMGB1, LL37, MPO and PR3 (Urban et al. 2009, Garcia-Romo et al. 2011). Release of ETs in a similar fashion as described above has also been reported for macrophages and mast cells (von Kockritz-Blickwede et al. 2008, Mohanan et al. 2013). This cell death mechanism can thus collectively be referred to as suicidal ETosis. 
After the initial discovery of ETs, it has been shown that ETs also can be released in a NADPH oxidase and/or ROS independent fashion (Yousefi et al. 2009, Pilsczek et al. 2010, Morshed et al. 2014, Rochael et al. 2015, Kraaij et al. 2016), and not to be associated with cell death. Release of ETs from viable neutrophils, eosinophils and basophils has been described, and is referred to as vital ETosis (Yousefi et al. 2008, Yousefi et al. 2009, Morshed et al. 2014). ETs released from these viable cells consist of mitochondrial DNA (or mtDNA ETs) instead of nuclear DNA, but contains granulae proteins similar to those ETs seen during suicidal ETosis. Antibacterial properties of these ETs were only evaluated for eosinophils, but were shown to both trap and kill bacteria in that study (Yousefi et al. 2008). mtDNA can also act as a danger signal and alert innate immunity (Nakahira et al. 2015). It has been shown that mtDNA also can induce NETs (Itagaki et al. 2015). This induced NET formation was shown to be ROS independent but whether the NETs were of nuclear or mitochondrial origin was not investigated (Itagaki et al. 2015).

The above described studies on neutrophils have been conducted on normal-density neutrophils. There is, however, also a neutrophil population referred to as low-density granulocytes (LDGs). Normally during isolation of neutrophils, LDGs end up in the cell fraction of peripheral blood mononuclear cells (PBMCs) and are therefore not analysed. Studies in SLE have shown that LDGs express increased levels of mRNA of various immunostimulatory bactericidal proteins and alarmins and that they release more NETs spontaneously than normal-density neutrophils (Villanueva et al. 2011). It has also been shown that mtDNA ETs from LDGs in SLE possess proinflammatory characteristics via DNA oxidation (Lood et al. 2016). Thus, it is important to consider these cells in future in vitro studies on NETs.

In addition to their role as antimicrobial agents, NETs of both nuclear and mitochondrial origin have been connected to autoinflammatory or autoimmune diseases (Gupta et al. 2005, Kessenbrock et al. 2009, Dwivedi et al. 2012, Khandpur et al. 2013, Leffler et al. 2013, Sur Chowdhury et al. 2014, Surmiak et al. 2015, Lood et al. 2016), and have therefore been referred to as a double edged sword of innate immunity (Kaplan and Radic 2012). 
Deoxyribonuclease I (DNaseI) has been shown in vitro to degrade NETs efficiently (Hakkim et al. 2010), and altered NET degradation capacity has between reported in patients with various inflammatory diseases compared with healthy controls (HC) (Leffler et al. 2012, Nakazawa et al. 2014). Also macrophages have been shown to aid in clearance of NETs (Farrera and Fadeel 2013, Nakazawa et al. 2016). Whether the release of ETs is ROSdependent or not, and is of nuclear or mitochondrial origin, seems to depend on the activation stimuli and should be further investigated. The exact role and mechanisms for ETs both as an antimicrobial agent in vivo as well as a trigger of autoimmunity needs to be further addressed to elucidate its importance in both these aspects.

\section{Antigen presentation}

Antigen presentation can be performed by all nucleated cells but there are also professional APCs. Antigen presentation is performed via a protein complex called the major histocompatibility complex (MHC). In humans MHC is sometimes referred to as human leukocyte antigens (HLA). There are two types of MHC that present antigens; MHC class I and MHC class II. MHC I is expressed by all nucleated cells in which endogenous (internal) antigens are constantly expressed with the purpose to represent the cells internal milieu. If cells fail to express MHC I molecules, for example during a virus infection, they are killed by NK cells, which then loose a negative signal mediated by MHC I. If cells express foreign peptides in the MHC I molecule, in particular during a virus infection, they are killed by specific $\mathrm{CD}^{+}$cytotoxic T cells. However, APCs (DCs, macrophages and B cells) can also present external antigens bound to MHC II molecules, for example peptides from phagocytosed microbes, eventually leading to activation of naïve CD4 ${ }^{+} \mathrm{T}$ helper (Th) cells. This process links innate and adaptive immunity. Several different signals are needed to activate $\mathrm{CD}^{+}{ }^{+} \mathrm{T}$ cells via $\mathrm{MHC}$ II; the first signal is that $\mathrm{T}$ cells recognize a peptide expressed by MHCII on APCs. The second signal is a co-stimulatory stimuli provided by the APC, such as via the molecules B7-1 (CD80) or B7-2 (CD86). These molecules are upregulated on APCs upon stimulation of PRRs by PAMPs or DAMPs, and the homeostatic low expression of them serve as a regulatory feature to prevent $\mathrm{T}$ cells from responding to self-antigens. Costimulatory molecules may also have inhibitory functions; for example PD-L1 and PD-L2 (Latchman et al. 2001, Klinker and Lundy 2012). There is also a third factor that activates T cells and shapes the $\mathrm{T}$ cell immune response, and that is the cytokines released by activated APCs (further explained in the T cell section below) (Abbas et al. 2012). 


\section{Adaptive immunity}

In contrast to innate immunity, adaptive immunity provides a slower but more specific immune response towards an antigen. Adaptive immunity also develops a memory towards each encountered antigen to be able to elicit a fast and effective response upon future exposure. These responses are provided by T and B cells. During development of B and T cells there is first a process referred to as central tolerance to generate functional cells that do not react to self-antigens. However, self-reactive cells are constantly generated and therefore a mechanism of peripheral tolerance is also important. By peripheral tolerance cells that react to self-antigens dies by apoptosis, become anergic (unresponsive) or are suppressed by regulatory cells (such as regulatory $\mathrm{T}$ (Treg) and B (Breg) cells). Thus central and peripheral tolerance are important mechanisms to avoid immune attacks the body's own cells, which can lead to autoimmune disease (Abbas et al. 2012).

\section{T cells}

$\mathrm{T}$ cell receptors (TCRs) on mature T cells recognize antigens presented by MHC molecules. Development of $\mathrm{T}$ cells and their TCR occurs in the thymus. T cells that cannot display a functional pre-TCR during early development miss survival signals and die by apoptosis. In the next step, $\mathrm{T}$ cells that can recognize MHC molecules with a low or moderate affinity via their TCR are positively selected. Cells that recognize MHC I molecules become $\mathrm{CD}^{+} \mathrm{T}$ cells and cells that recognize MHC II molecules become $\mathrm{CD} 4^{+} \mathrm{T}$ cells. However, $\mathrm{T}$ cells that reacts too strongly to self-antigens die by apoptosis (negative selection) to limit the risk for autoimmunity (Abbas et al. 2012). An important cell type in peripheral tolerance to limit autoreactive cells are Treg cells, which also develops in the thymus, sometimes referred to as natural Treg cells as opposed to induced or peripheral Treg cells that are developed outside thymus (Caramalho et al. 2015).

$\mathrm{CD}^{+} \mathrm{T}$ cells recognize viral antigens in MHC I of DCs and eventually differentiate into effector cytotoxic T lymphocytes (CTLs) that kill infected cells that express these viral antigens on MHC I. CD4 ${ }^{+}$Th cells can differentiate into several different subpopulations, where Th1, Th2, Th17 and Treg cells are well-known and established subpopulations (Abbas et al. 2012). 
Activation of NF-kB and AP-1 in APCs skew the immune response towards a proinflammatory response, which promotes differentiation of Th1 (IL-12) and Th17 cells (proIL-1 $\beta$, proIL-18, IL-6 and IL-23), respectively. Activation of the transcription factor CREB promotes IL-10 production, which can induce Treg cells (Mills 2011). Th1 cells produce proinflammatory cytokines such as interferon-y (IFN- $\gamma$ ) and TNF and are important in intracellular viral and bacterial infections. Th17 cells also produce proinflammatory cytokines (for example IL-17 and IL-22) and are important for clearance of extracellular bacteria and fungi. Treg cells are important to regulate and balance proinflammatory responses via release of IL-10 and through contact-dependent mechanisms (Schmidt et al. 2012). Differentiation of Th2 cells require IL-4 and promotes allergy and responses to helminths and protozoa via production of IL-4, IL-5 and IL-13 (Abbas et al. 2012). The initial source for IL-4 could be mast cells or eosinophils that may be activated by helminths (Serhan et al. 2010, Abbas et al. 2012).

\section{B cells}

$\mathrm{B}$ cells are best known as precursors to antibody producing plasma cells but they are also professional APCs, important producer of cytokines and can aid in immune regulation, both via cytokine dependent and independent mechanism. They recognize structures via their BCR. In mice there are two distinct lineages of B cells, referred to as B1 and B2 B cells. B2 B cells are further divided into MZ B cells and follicular B cells. Whereas the maturation stages for follicular B cells in humans are well-studied, less is known about the human counterparts of B1 and MZ B cells. There are, however, human B cells that show functional similarities to the corresponding B1 and MZ B cells in mice but whether they are the exact counterpart is not known yet (Bemark 2015). In figure 1, we have summarized what is established for human B cell development as well as possible development pathways for B1like and MZ-like B cells as well as regulatory B (Breg) cell subpopulations. 
During early development of B2 cells in the bone marrow, the BCR is developed via various steps of changes in Ig gene expression (gene recombination/rearrangement) and Ig protein expression (heavy and light chain), which constitute the BCR. Only B cells that display a functional BCR receive survival signals to avoid apoptosis, enabling them to become immature B cells with a functional IgM BCR. After this positive selection there is a negative selection of B cells that react too strongly to self-antigens. In mice negative selection occurs in the spleen but in humans it takes place in the bone marrow and/or possibly in peripheral lymphoid organs. In the case of too strong antigen interaction the cells can undergo receptor editing to change the affinity of the BCR for the self-antigen or undergo apoptosis (negative selection). As B cells develop they are referred to as transitional 1, 2 and 3 B cells, followed by mature naïve $\mathrm{B}$ cells that now also express $\operatorname{IgD}$ on the cell membrane. These cells are referred to as follicular B cells, which constitute a pool of cells that together can recognize any possible antigen. They recirculate between lymph nodes and spleen follicles in search for microbes, and upon encountering an antigen follicular B cells can differentiate into long-lived high affinity antibody producing plasma cells. Via additional B cell gene rearrangements (class-switch) but also mutations (somatic hyper-mutations) and selection processes only $\mathrm{B}$ cells that are highly specific for this particular antigen survive the process and produce high affinity IgG antibodies. Most B-cells leaving the follicular zones develop into plasma cells that reside in the bone marrow and produce antibodies continuously, whereas some follicular B-cells become memory B cells that can recognize previously detected microbes quickly upon future encounter (Abbas et al. 2012).

\section{Innate-like B cells - B1 and marginal zone B cells}

In mice, some B cells primarily colonize the marginal zone of the spleen and are referred to as MZ B cells. The marginal zone is a strategically located position to encounter antigens as it is the interface of the blood circulation and the immune system (Allman and Pillai 2008, Cerutti et al. 2013). Theories of B1 B cell development is that they develop from a progenitor stem cell distinct from B2 B cells, and because of restricted gene rearrangement they are suggested to be of fetal origin (Baumgarth 2011). 
Another theory is that B1 B cells similar to B2 B cells stem from a common bone marrow precursor. Nevertheless, in mice B1 B cells primarily reside in pleural and peritoneal cavities (Baumgarth 2011). Both B1 and MZ B cells show somewhat altered tissue distribution in humans compared with mice, where MZ-like B cells in humans in addition to the spleen also localize to payer's patches, tonsils and activated lymph nodes, and they also tend to recirculate. Regarding B1 B cells, humans in contrast to mice only have few of these B cells in the peritoneum (Bemark 2015).

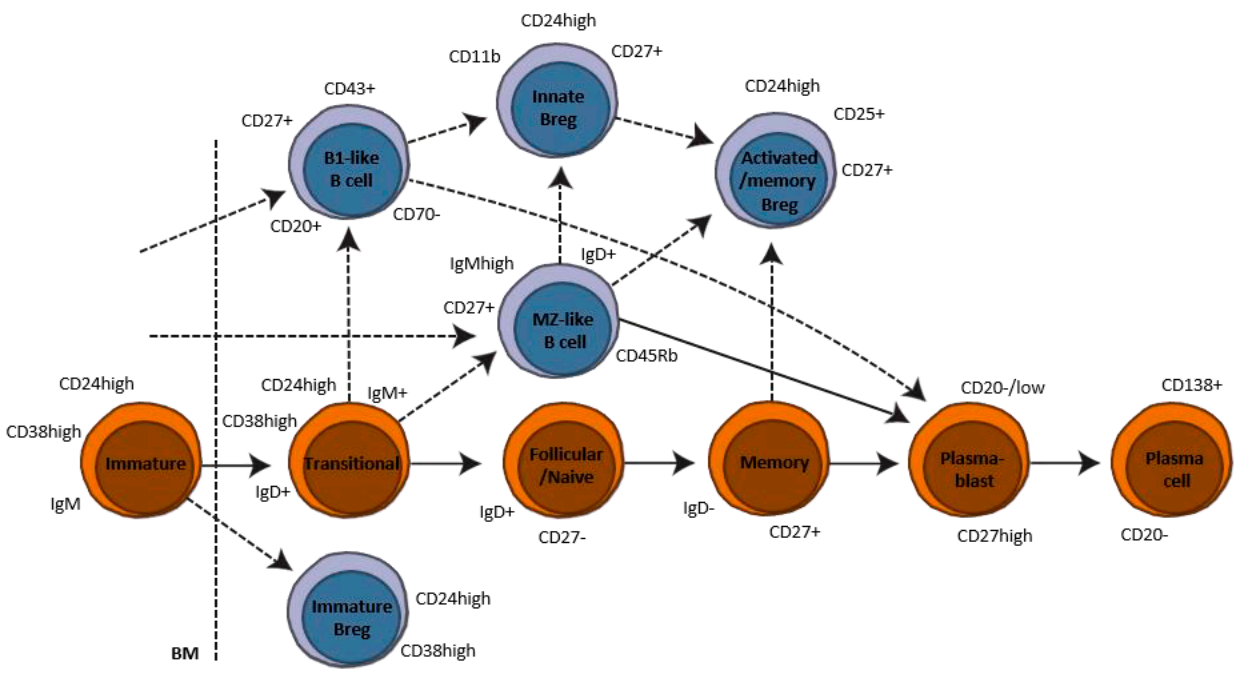

Figure 2. Overview of human B cell development and proposed innate-like B cells and Breg cell populations. Solid lines indicate established human B cell maturation stages from immature B cell to antibody producing plasma cells. Dotted lines show suggested/possible development pathways for innate-like B cells as well as a set of proposed Breg cell populations in humans. Cells in blue colour include populations that we investigated in paper IV. CD-molecules associated or suggested with the different subpopulation are also presented.

Both B1 and MZ B cells show restricted gene rearrangements. Thus, they produce antibodies as explained earlier of low-affinity but with broad specificity, mostly $\operatorname{IgM}$, and these antibodies can bind to conserved microbial structures as well as to self-antigens, and belong to the pool of natural antibodies (Baumgarth 2011, Cerutti et al. 2013). A feature of B1 B cells is that they can produce IgM spontaneously, without prior antigen exposure. In contrast to spontaneous antibody production, both $\mathrm{B} 1$ and $\mathrm{MZ} \mathrm{B}$ cells can also respond to antigens in a TI pathway, and differentiate into short-lived plasma cells. This occurs without interacting with T cells. B1 B cells can respond to TLR signalling whereas MZ B cells can respond to both TLR or BCR stimulation for this purpose (Allman and Pillai 2008). 
Both MZ and B1 B cells can also undergo class-switching during T cell independent responses. In mice, B1 B cells have been shown to primarily switch to produce IgA antibodies (Baumgarth 2011) whereas MZ B cells can produce IgG and IgA, which is also true for MZ-like B cells in humans (Cerutti et al. 2013). MZ B cells can also differentiate into antibody producing cells towards T cell dependent (TD) antigens (Cerutti et al. 2013).

Another feature of humans MZ B cells is that they can interact with neutrophils that are called B cell helper neutrophils. It has been suggested that optimal stimulation of human $\mathrm{MZ}$ B cells could involve NETs.By capture of antigens in the NETs, NETs could provide simultaneous TLR and BCR stimulation (Cerutti et al. 2013).

\section{Regulatory B (Breg) cells}

$\mathrm{B}$ cells with immune regulatory features are referred to as Breg cells. These cells are important to dampen inflammatory processes, autoimmunity and transplant rejection. There is no consensus regarding the exact phenotype for Breg cells as transitional and a wide range of B cells can exert regulatory mechanisms (Mauri and Menon 2015). Various human Breg cells have together been shown to produce for example IL-10, transforming growth factor beta (TGF $\beta$ ), indoleamine 2,3-dioxygenase (IDO) and granzyme and to exert cell-contact dependent mechanisms via CD80/86 and PD-L1. Mechanisms include dampening of Th1 and Th17 activation and proliferation, T cell apoptosis as well as induction of Treg cells (Mauri and Menon 2015).

The IL-10 producing B cells have been shown to be enriched within the transitional $\left(\mathrm{CD} 24^{\text {high }} \mathrm{CD} 38^{\text {high }}\right)$ (Blair et al. 2010) and memory $\left(\mathrm{CD} 24^{\text {high }} \mathrm{CD} 27^{+}\right)$B cell population (Iwata et al. 2011). It has also been shown that when dividing B cells into CD25 $5^{+}$and CD25 cells, those that are $\mathrm{CD} 25^{+}$produce more IL-10 upon TLR9 stimulation (Amu et al. 2007). In line with this, those that produce IL-10 upon TLR9 stimulation within the CD $24{ }^{\text {high }} \mathrm{CD} 27^{+} \mathrm{B}$ cells consisted of somewhat more $\mathrm{CD}_{2} 5^{+} \mathrm{B}$ cells than those that did not produce IL-10. A B1 B cell population that expresses CD11b produce IL-10 spontaneously, and $60 \%$ of these can be found within the $\mathrm{CD} 24^{\text {high }} \mathrm{CD} 27^{+}$population (Griffin and Rothstein 2012), suggesting that there could be a mix of innate-like and memory B cells within this population. $\mathrm{CD} 24^{\text {high }} \mathrm{CD} 38^{\text {high }}, \mathrm{CD} 24^{\text {high }} \mathrm{CD} 27^{+}$and $\mathrm{CD} 25^{+} \mathrm{B}$ cells appear to also be able to exert contactinhibitory mechanisms (Tretter et al. 2008, Blair et al. 2010, Zha et al. 2012). 
In addition to these, other Breg cells characterized as $\mathrm{CD} 48^{+} \mathrm{CD} 148^{+}$or $\mathrm{CD} 73-\mathrm{CD} 25^{+} \mathrm{CD} 71^{+}$ B cells have also been described (Nouel et al. 2014). The studies on contact-dependent mechanisms of Breg cells have so far mainly focused on the role of CD80 and CD86 (Blair et al. 2010, Iwata et al. 2011, Kessel et al. 2011) but the expression of the negative costimulatory molecules programme death ligands (PD-L) 1 (CD274) and PD-L2 (CD273) would also be of great interest to study on Breg cells as these are known to be involved in immune regulation (Francisco et al. 2010). In addition to the described Breg cell populations above it has also been shown that activated $\mathrm{T}$ cells in co-culture with unstimulated $\mathrm{B}$ cells can induce Breg cells via CD40 ligand stimulation, and that these B cells in turn can regulate T cell activation (Lemoine et al. 2011). Similar results, as well as induction of Treg cells, have been obtained when culturing activated T cells with B cells in the presence of CpG (TLR9 stimulation). These cells produced TGF $\beta$ and IDO (Nouel et al. 2015).

\section{AAV pathogenesis}

During a typical inflammatory response, there are several crucial steps that takes place; neutrophil migration to the inflammatory site, adherence to the endothelium, entrance to the extravascular space and migration to the triggering agent (such as a microbe). Neutrophils are then activated and after resolving the situation they either leave the tissues via draining lymph nodes or are phagocytosed by macrophages after undergoing apoptosis (Serhan et al. 2010)

Similar to the typical inflammatory process, neutrophils can be observed early in the vessels of AAV patients, but differently from the process of resolution of inflammation, neutrophils undergo both apoptosis and necrosis within hours at the inflammatory site. In both necrotizing- glomerulonephritis and granulomatous, neutrophils are absent at later stages of the inflammation. Biopsies of glomeruli then show monocytes, macrophages and T cells, whereas granuloma formation is characterized by an extravascular formation of organized lymphoid follicles containing T cells, B cells, DCs macrophages and plasma cells (Jennette and Falk 2014). Nevertheless, neutrophils are the driving force in the early stages of inflammation in these diseases. 


\section{Neutrophil recruitment}

Regardless of the initial trigger, a typical acute inflammatory response is associated with several changes that occur in the vascular compartment. DCs and tissue macrophages in the tissues are activated and release proinflammatory mediators such as TNF and IL-1 $\beta$ that activates endothelial cells and the chemokines CXCL8 and CCL2 that aids in recruitment of neutrophils and monocytes, respectively (Serhan et al. 2010). Other neutrophil chemoattractants include C5a, C3a, N-formylmethionine-leucyl-phenylalanine (fMLP) and leukotriene B4 (Phillipson and Kubes 2011). AAV is considered pauci-immune, with only few immune complex depositions. However, many studies have shown the complement factor C3 to be deposited in glomeruli of patients (Chen et al. 2009), and patients possess an aberrant expression of the $\mathrm{C} 3$ gene (Persson et al. 2013). Both C3a and C5a, which is important for neutrophil recruitment, appear to be increased in plasma and urine samples of active patients. Several evidence points towards a role for the alternative complement system; Factor $\mathrm{H}$ and properdin but not $\mathrm{C} 4 \mathrm{~d}$ (classical pathway) and MBL (lectin pathway) are present in glomerular biopsies (Xing et al. 2009), and Bb of the fluid phase C3 convertase (alternative pathway) are elevated in the circulation during active disease, whereas properdin is reduced (Kallenberg and Heeringa 2015). The alternative pathway is also particularly important in a MPO-ANCA mice model, as only inhibition of this pathway could rescue the mice from developing disease (Xiao et al. 2007). Further, inhibition of C5 in mice protected against glomerulonephritis and C5-deficient mice did not develop disease, and treatment with a C5aR blocker strongly reduced development of renal lesions (Schreiber et al. 2009, Xiao et al. 2014).

Increased vasopermeability and upregulation of selectins and integrin on activated endothelial cells are important to allow adherence and subsequent migration of neutrophils and monocytes out of the vessel. Increased vasopermeability is mediated by certain prostaglandins released from macrophages and mast cells, histamine released from mast cells activated by C3a, and bradykinin (Serhan et al. 2010, Hofman et al. 2016). 
Bradykinin can also promote inflammation by inducing production of TNF and IL- $1 \beta$ from macrophages, and blockade of its receptor can ameliorate glomerulonephritis in mice (Klein et al. 2010). PR3 released by activated neutrophils promotes formation of bradykinin and thereof increased vasopermeability and inflammation (Kahn et al. 2009). This can be inhibited by the PR3 inhibitor $\alpha 1$-antitrypsin, but the genetic variations of this gene in AAV patients (Rahmattulla et al. 2016) could possibly disrupt this regulation.

\section{Neutrophil activation}

Once recruited to the site of inflammation, C5a and the chemoattractant fMLP released from bacteria or host cells (as fMLP is a mitochondrial DAMP) are important for neutrophil extravascular migration and activation via the C5a receptor and FPR1 receptor, respectively (Phillipson and Kubes 2011). Neutrophils express several PRRs; all TLRs except TLR3, dectin 1 (CLR) and CLEC2, RIG-1 and MDA5 (RLRs) and NOD1 (Mantovani et al. 2011). These receptors and FPR1 make the neutrophil capable of sensing a great variety of PAMPs and DAMPs that can elicit the neutrophils effector functions. Neutrophils are also activated by ANCA via membrane bound MPO and PR3. Phagocytosis, degranulation of proteolytic enzymes and release of ROS as well as NETs are direct proinflammatory mechanisms, but neutrophils can also promote inflammation by orchestrating the immune system in several other ways (Nathan 2006, Korkmaz et al. 2010, Mantovani et al. 2011), as depicted in Fig. 3. An important mechanism is the recruitment of both macrophages and DCs through formation of chemerin via Cathepsin G and Azurocidin, as well as activation of these cells via cytokines such as TNF (Nathan 2006). Neutrophils compose four different granules in the cytoplasm; azurophilic/primary, specific/secondary, gelatinase/tertiary granules and secretory vesicles. Their different names indicate the order they are formed during neutrophil development. These are membrane-enclosed compartments that contain potentially harmful substances used in the defence towards pathogens; upon neutrophil activation they are released to the surrounding milieu after fusion with the cell membrane or into the phagosome during phagocytosis to kill pathogens (Amulic et al. 2012). Below follows a more detailed descriptions of the role of PR3, MPO, ANCA and NETs in AAV. 


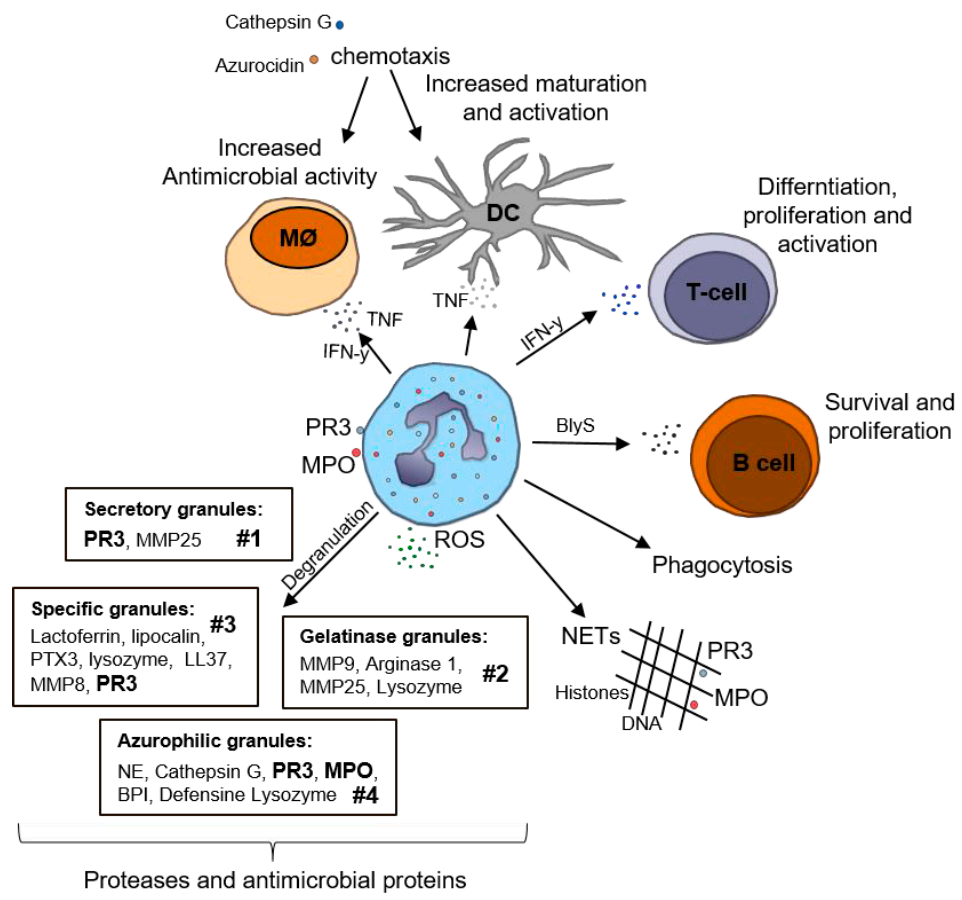

Figure 3. Neutrophil effector functions. Neutrophils exert several mechanisms that promotes inflammation upon activation; both directly via degranulation of granule content (\#1-4 designates in which order the granules are emptied during neutrophil activation), ROS production, NET formation and upregulation of PR3 and MPO, and indirectly via activation of both immune cells of innate (macrophages and DCs) and adaptive immunity ( $\mathrm{T}$ and $\mathrm{B}$ cells). 


\section{PR3 and MPO}

Proteinase 3 is a serine protease that can be found in specific, secretory and azurophilic granules, but is also constitutively expressed on the cell membrane in quiescent cells (Korkmaz et al. 2010). The constitutively expressed PR3 is enzymatically inactive (van Rossum et al. 2004), but upon priming there is an upregulation of PR3 on the cell surface that is enzymatically active. Neutrophil priming is achieved by proinflammatory mediators such as TNF (Falk et al. 1990), LPS (Huugen et al. 2005) and C5a (Schreiber et al. 2009). PR3 is involved in bacterial killing in phagolysosomes during phagocytosis in combination with MPO and ROS, but can also degrade extracellular matrix components and induce apoptosis in endothelial cells (Korkmaz et al. 2010). Another interesting feature is its capability to activate proinflammatory mediators; for example IL-1 $\beta$ and IL-18 that otherwise is cleaved by caspase-1 in inflammasomes (Korkmaz et al. 2010). All these mechanisms promote inflammation upon neutrophil activation. PR3-ANCA/GPA patients show a genetic defect for the natural inhibitor for PR3, $\alpha 1$-antitrypsin, suggesting that regulation of the activity of PR3 is important (Lyons et al. 2012).

PR3 shows a bimodal membrane expression patterns, where neutrophils with low and high membrane PR3 expression (mPR3 ${ }^{\text {low }}$ and $\mathrm{mPR} 3^{\text {high }}$, respectively) can be distinguished (Halbwachs-Mecarelli et al. 1995), and it has been shown that mPR $3^{\text {high }}$ neutrophils are more strongly activated by ANCA compared with mPR3low neutrophils (Schreiber et al. 2004). It has previously been shown that neutrophils from AAV patients possess increased membrane expression of PR3 (Csernok et al. 1994, Witko-Sarsat et al. 1999). Epigenetic silencing of the PR3 and MPO gene has been reported to be disrupted in these patients (77), which could possibly explain the altered membrane PR3 expression. A increased percentage of cells that express PR3 on the cells surface is suggested to be related with higher risk to develop GPA (Witko-Sarsat et al. 1999), and to relapse (Rarok et al. 2002).

Resolution of inflammation is a fundamental part of the inflammatory process, to avoid excessive inflammation due to for example secondary necrosis. During phagocytosis of apoptotic cells, macrophages releases anti-inflammatory agents such as TFG- $\beta$ and prostaglandin E2 and are skewed towards a M2 or resolution phenotype, specialised in scavenging dead cells (Fadok et al. 1998). PR3 is increased on apoptotic neutrophils, unrelated to degranulation, and can interfere with the phagocytosis by macrophages, leading to reduced phagocytosis (Kantari et al. 2007). 
A system that uses apoptotic rat basophilic leukaemia (RBL) cells transfected with the PR3 suggests that macrophages become proinflammatory in this scenario and release CCL2 to recruit more monocytes, promoting inflammation (Gabillet et al. 2012).

MPO can be found in azurophilic granules and belongs to the heme peroxidase family. It is expressed to a lower extent than PR3 on the cell membrane on resting neutrophils but ANCA can bind to and activate neutrophils also via MPO on the cell surface after priming (Kettritz 2012). The product generated by MPO is hypochlorous acid (HOCL) and is highly toxic and can react with and oxidize macromolecule such as proteins, DNA and lipids. MPO exert its mechanism during phagocytosis within the phagolysosome, upon degranulation as being part of the released granule content and when present in NETs upon NETosis (Prokopowicz et al. 2012).

MPO can also be internalized by endothelial cells and affect these to produce ROS (Yang et al. 2001), stimulate macrophages to release TNF (Lefkowitz et al. 1999) as well as delay neutrophil apoptosis (El Kebir et al. 2008), where all mechanisms promote inflammation. MPO also promotes the effects of PR3 by inactivating its inhibitor $\alpha 1$-antitrypsin. It has been shown that the plasma protein ceruloplasmin normally inhibit the activity of MPO (Segelmark et al. 1997), but that MPO-ANCA can interfere with this inhibition, prolonging the proinflammatory effects of MPO (Griffin et al. 1999). Thus, indirectly MPO-ANCA also affects the activity of PR3. It does, however, appear to also be other regulatory mechanisms, such as that HOCL via oxidations not only promote proinflammatory responses but also can inactivate enzymes such as MMP7 and catephsin G as well as MPO itself (Prokopowicz et al. 2012).

\section{ANCA}

The first direct evidence for a role of ANCA in the pathogenesis was revealed in 1990 by Jeannette et al. when they observed in vitro that ANCA could activate primed neutrophils to produce ROS and degranulate (Falk et al. 1990). ANCA have since also been shown to activate neutrophils in vitro to release proinflammatory mediators such as IL-1 $\beta$ (Brooks et al. 1996), CXCL8 (Cockwell et al. 1999) and NETs (Kessenbrock et al. 2009, Sha et al. 2016), and to activate the alternative complement pathway (Xiao et al. 2007, Schreiber et al. 2009). 
It has also been shown that ANCA promotes neutrophil adhesion to- and transmigration through the endothelium (Radford et al. 2000, Radford et al. 2001), as well as can activate neutrophils to cause endothelial cell damage (Ewert et al. 1992).

It appears that the $\mathrm{F}(\mathrm{ab}) 2$ and $\mathrm{Fc}$ part of ANCA IgG triggers distinct signalling pathways but that full activation of neutrophils depends on interactions of both the $F(a b) 2$ part with its antigen as well as their Fc part to FcRs, which is mainly FcRIIa and FcRIIIb that are constitutively expressed on neutrophils (Kettritz 2012). Several factors affect the potential of ANCA activation. Certain epitopes for both MPO-ANCA (Roth et al. 2013) and PR3-ANCA have been suggested to be of importance in AAV (Kuhl et al. 2010, Silva et al. 2010). In the case of MPO-ANCA, it has been shown that epitope specificity varies with disease activity and that ANCA activate neutrophils to produce ROS more profoundly during active disease (Roth et al. 2013). Further, it has also been shown that MPO-ANCA have higher affinity for MPO during active disease and that ANCA during active disease induce more NETs (Nakazawa et al. 2014). Hence, it seems that both epitope specificity and affinity is important for neutrophil activation by ANCA. Whether this is as important for PR3 ANCA as for MPOANCA is not settled.

As already mentioned, animal models have been successful in showing the importance of the alternative complement pathway in AAV. They have also been used to show that MPOANCA can cause disease, but have been less successful for PR3-ANCA mediated disease. The problem with developing a PR3-ANCA model is for example due to the differences between rodent and human PR3. Some have for example instead chosen to transfect RBL cells with human PR3 to provide a tool to study PR3 expressing cells in vivo in mice (of which I mentioned an example earlier when studying clearance of apoptotic cells) (Millet et al. 2015).

The principle of the successful MPO-ANCA model is that anti-MPO antibodies raised in MPO-deficient mice upon immunization with purified murine MPO are transferred to wildtype mice, which develop necrotizing pauci-immune glomerulonephritis. Mice that lack functional $\mathrm{B}$ and $\mathrm{T}$ cells did also develop disease, suggesting a minor role for $\mathrm{T}$ cells in this model (Xiao et al. 2002). 


\section{Neutrophil extracellular traps (NETs)}

\section{Presence in biopsies and plasma/serum}

A suggested explanation for the necrotic portion of these cells at vasculitic lesions is that they are (or at least contain) NETotic neutrophils. In 2009 Kessenbrock et al. was first to show that NETs were present in glomeruli in kidney biopsies(Kessenbrock et al. 2009). The conclusion was drawn from histological observations of co-localizations of DNA, histones and the granule proteins PR3, LL37, NE and MPO in various combinations. The presence of NETs in glomeruli in AAV have then been confirmed by others (Yoshida et al. 2013, O'Sullivan et al. 2015, Tang et al. 2015), and NETs have also been shown to be present in skin lesions (Abreu-Velez et al. 2009, Sangaletti et al. 2012) and thrombi (Nakazawa et al. 2012, Imamoto et al. 2014) from patients. In addition to the histological findings of NETs in biopsies, elevated levels of NETs in the circulations have also been identified in patients (Table I) (Kessenbrock et al. 2009, Surmiak et al. 2015, Surmiak et al. 2016, Wang et al. 2016). Similar results as for NETs have been obtained for NET-associated components such as HMGB1, calprotectin, PR3, MPO, and NE as well as mtDNA when measured separately in the circulation (Table 1) (Henshaw et al. 1994, Haubitz et al. 1997, Ohlsson et al. 2003, Wibisono et al. 2010, Bruchfeld et al. 2011, Pepper et al. 2013, Surmiak et al. 2016). Although these findings do not reveal whether the components are released as a result of NETosis or not, it was recently shown that the levels of MPO and NE correlate with the levels of DNA/MPO complexes in the circulation, suggesting such a relationship (Surmiak et al. 2016). Several studies have also shown that neutrophils in patients possess increased spontaneous NETosis compared with HC (Grayson et al. 2015, Tang et al. 2015), which could contribute to the elevated levels in the circulation. One of these studies showed that both normal density neutrophils and LDGs in patients released more NETs than normaldensity neutrophils in HC, but also showed that LDGs appear to be the main source of NETs in the patients (Grayson et al. 2015). 
Table I: NET-associated proteins and structures present in the circulation of AAV patients

\begin{tabular}{|c|c|c|c|}
\hline Protein/structure & Method & AAV vs. HC & $\begin{array}{l}\text { Correlation with } \\
\text { disease activity }\end{array}$ \\
\hline $\begin{array}{l}\text { Nucleosome + MPO } \\
\text { Complexes }\end{array}$ & ELISA & $\begin{array}{l}+(\text { Kessenbrock et al. 2009, } \\
\text { Surmiak et al. 2016) }\end{array}$ & $\begin{array}{l}\text { yes (Kessenbrock et al. 2009, } \\
\text { Surmiak et al. 2016) }\end{array}$ \\
\hline $\begin{array}{l}\text { DNA + MPO or citrullinated } \\
\text { histone } 3 \text { complexes }\end{array}$ & ELISA & + (Wang et al. 2016) & no (Wang et al. 2016) \\
\hline DNA + histone complexes & ELISA & $+($ Surmiak et al. 2016) & no (Surmiak et al. 2016) \\
\hline DNA & PicoGreen & + (Wang et al. 2016) & no (Wang et al. 2016) \\
\hline mtDNA & qPCR & $+($ Surmiak et al. 2015) & yes (Surmiak et al. 2015) \\
\hline Nuclear DNA & qPCR & + (Surmiak et al. 2015) & no (Surmiak et al. 2015) \\
\hline PR3 & ELISA/Luminex & $\begin{array}{l}\text { + (Baslund et al. 1994, } \\
\text { Henshaw et al. 1994, } \\
\text { Ohlsson et al. 2003, } \\
\text { Ohlsson et al. 2005, } \\
\text { Surmiak et al. 2016) }\end{array}$ & no (Surmiak et al. 2016) \\
\hline MPO & ELISA & $+($ Ohlsson et al. 2005) & yes (Surmiak et al. 2016) \\
\hline HMGB1 & $\begin{array}{l}\text { Western blot/ } \\
\text { ELISA }\end{array}$ & $\begin{array}{l}\text { + (Wibisono et al. 2010, } \\
\text { Bruchfeld et al. 2011, } \\
\text { Wang et al. 2013) }\end{array}$ & $\begin{array}{l}\text { yes (Wibisono et al. 2010, } \\
\text { Bruchfeld et al. 2011, Wang } \\
\text { et al. 2013) }\end{array}$ \\
\hline Calprotectin & ELISA & + (Pepper et al. 2013) & yes (Pepper et al. 2013) \\
\hline $\mathrm{NE}$ & ELISA/Luminex & $\begin{array}{l}\text { + (Haubitz et al. 1997, } \\
\text { Surmiak et al. 2016) }\end{array}$ & $\begin{array}{l}\text { yes (Haubitz et al. 1997, } \\
\text { Surmiak et al. 2016) }\end{array}$ \\
\hline
\end{tabular}

Superscript numbers indicate referenced publication; AAV: ANCA-associated vasculitis; HC: healthy blood donors; +: increased levels; nd: not determined; PR3: proteinase 3; HMGB1: high-mobility group box 1 protein; MPO: myeloperoxidase; mtDNA: mitochondrial DNA; nDNA: nuclear DNA; NE: neutrophil elastase. Reused from ref. Soderberg and Segelmark 2016, with permission according to the Creative Commons Attribution License (CC-BY 4.0). 


\section{Inflammatory features and regulation}

The above studies imply a role for NETs in the pathogenesis of AAV. The general capability of NETs to cause endothelial damage (Gupta et al. 2010, Villanueva et al. 2011, Saffarzadeh et al. 2012) as well as activating the alternative complement pathway (Wang et al. 2015) are mechanisms that indeed fit with the pathogenesis of AAV. Gupta et al. showed that neutrophil chemoattractant CXCL8 is released from endothelial cells activated by NETs, and that CXCL8 can induce NETosis (Gupta et al. 2010). This could contribute to an amplification loop of NET formation, endothelial cell activation with recruitment and activation of more neutrophils via CXCL8. Anti-histone antibodies limit development of glomerulonephritis in an experimental setting, stretching the importance of histones as proinflammatory mediators in NETs (Kumar et al. 2015). A frequent observation in AAV is leukocytoclasia, which is fragmentation of nuclei, in combination with fibrin depositions. NETs contain fibrillary material as well as express tissue factor which promotes fibrin formation and could explain these histologically features (Jennette and Falk 2014). NETs can also promote thrombus formation via histones and tissue factor in the NETs and activated platelets, for example via HMGB1 expressed on the platelets, can induce NETs (Fuchs et al. 2010, von Bruhl et al. 2012, Kambas et al. 2014, Maugeri et al. 2014, Huang et al. 2015). This is in line with the increased risk of thrombus formation in AAV as well as the presence of NETs in thrombi. As shown for NETs, P-selectin is increased during active disease and seem to correlate with disease activity (Surmiak et al. 2016). Of note is that HMGB1, which appear to be increased during active disease, also can potentiate the effect of ANCA activation on NET formation (Ma et al. 2016). In addition to the proinflammatory mechanisms exerted directly by histones and other proteins in the NETs, DNA of both nuclear and mitochondrial origin can act as DAMPs and contribute to inflammation via activation of DNA sensing PPRs such as TLR4, TLR9, AIM2 and IFI16 (O'Neill et al. 2013, Nakahira et al. 2015). 


\section{T cells}

Elevated levels of IL-17 and its upstream initiator of Th17 cell differentiation have been reported in the circulation of AAV patients (Nogueira et al. 2010), as well as increased levels of IL-17 and its downstream Th17 cell chemoattractant CCL20 (MIP-3a) in active AAV (Eriksson et al. 2015). IL-17 can activate endothelial cells to express adhesion molecules and to produce CXCL8 and CCL2, which is of interest in AAV as these events promote neutrophil and monocyte recruitment and infiltration (Ooi et al. 2010). Th17 cells also activate macrophages to release TNF and IL-1 $\beta$ (Jovanovic et al. 1998). It appears that the pool of Treg cells in AAV patients that is normally important in peripheral tolerance to limit inflammatory responses, including those by Th17 cells, are dysfunctional in their regulatory capacity (Abdulahad et al. 2007, Morgan et al. 2010, Mills 2011, Rimbert et al. 2011).

\section{B cells}

As ANCA is implicated in the pathogenesis of AAV, B cells that are precursors to plasma cells have naturally been thought to be important. Usage of rituximab that depletes circulating B cells has been efficiently used to induce remission (Eriksson 2005, Stone et al. 2010). However, clinical remission is achieved before a decline in ANCA (Stone et al. 2010), implying that B cells also are involved via other mechanisms than antibody production, such as interactions with $\mathrm{T}$ cells and cytokine production. B cells are present in renal biopsies from AAV patients and stained positive for MHC II, suggesting a role as antigen presenting cells at these sites (Steinmetz et al. 2008). In addition to this, also anti-inflammatory cytokines are dysregulated in AAV. IL-10 has been shown to be increased during remission and tend to fall prior to remission (Ohlsson et al. 2004, Land et al. 2015), suggesting regulatory defects in regulatory cells such as Treg and Breg cells. A defect in Treg cells has already been described (above), but maybe there is also a defect in the repertoire of Breg cells.

Several studies have now investigated the frequencies and function of Breg cells in AAV, although with conflicting results. Both phenotypic as well as functional studies have been conducted, where the functional studies have primarily focused on measurements of IL-10 intracellularly after stimulation in vitro. However, one study measured the effect of total B cells on TNF produced by monocytes (Lepse et al. 2014), whereas another study evaluated suppression on Th1 cell activation by $\mathrm{CD} 24^{\text {high }} \mathrm{CD} 38^{\text {high }} \mathrm{B}$ cells (Todd et al. 2014). These two studies did not observe any differences between patients and HC. 
Regarding IL-10 positive B cells upon stimulation, Aybar et al. showed that the proportion of these cells within the $\mathrm{B}$ cell population were reduced during active disease, but that this population rebounded during remission (Aybar et al. 2015). Wilde et al. however, reported reduced proportions of $\mathrm{IL}-10^{+} \mathrm{B}$ cells in both remission and active patients (Wilde et al. 2013), whereas Lepse et al. did not observe any differences of IL-10 positive B cells between patients with different disease activity or with HC (Lepse et al. 2014). Technical differences during culturing and stimulation of B cells could explain some of the different results in the studies.

In addition to these functional studies, phenotypical studies have also been performed, where populations suggested to be enriched for Breg cells have been investigated. These studies include measurements of $\mathrm{CD}^{+}$(Eriksson et al. 2010, Bunch et al. 2013, Bunch et al. 2015, Unizony et al. 2015, Land et al. 2016), CD24 $4^{\text {high }}$ CD $38^{\text {high }}$ (Lepse et al. 2014, Todd et al. 2014, Aybar et al. 2015, Land et al. 2016), CD24 ${ }^{\text {high }}$ CD27 $7^{\text {high }}$ (Lepse et al. 2014, Aybar et al. 2015, Land et al. 2015), $\mathrm{CD}^{+} \mathrm{CD} 24^{\text {high }} \mathrm{CD}^{38 \text { high }}$ (Aybar et al. 2015) and $\mathrm{CD} 25^{+} \mathrm{B}$ cells (Eriksson et al. 2010). The results from different studies on $\mathrm{CD}^{+}, \mathrm{CD} 24^{\text {high }} \mathrm{CD} 38^{\text {high }}$ and $\mathrm{CD} 24^{\text {high }} \mathrm{CD} 27^{\text {high }}$ differ in the results, where the frequencies of the respective population have been shown to be altered in patients in some studies but not all. Promising results were, however, reported for $\mathrm{CD}^{+} \mathrm{CD} 24^{\text {high }} \mathrm{CD} 38^{\text {high }} \mathrm{B}$ cells, which were reduced during active disease but rebounded during remission. $\mathrm{CD} 25^{+} \mathrm{B}$ cells has only been investigated in one study in AAV, but was shown to be increased during remission. Return of naïve B cells (which include CD24 ${ }^{\text {high }} \mathrm{CD} 38^{\text {high }} \mathrm{B}$ cells) (Md Yusof et al. 2015) rather than memory B cells (CD27) is, however, connected to reduced risk of relapse, indicating a role for those B cells in immune regulation (Venhoff et al. 2014). 


\section{Generation of ANCA}

PR3-ANCA and MPO-ANCA can be found in the circulation of healthy individuals (Cui et al. 2010), implying that ANCA belong to the repertoire of natural antibodies produced by innate-like B cells. However, patients that develop AAV show elevated levels of these autoantibodies and they are suggested to be involved in the pathogenesis by activating neutrophils and monocytes via PR3 and MPO when expressed on the cell surface (Jennette and Falk 2014). If so, the question is what events that culminates in the break of tolerance and production of pathogenic MPO- and PR3-ANCA.

During the germinal center reaction, B cells interact with a subpopulation of T cells referred to as $\mathrm{T}$ follicular (Tf) helper cells, which is increased in the circulation of GPA patients (Abdulahad et al. 2013). Their main function is to interact with B cells during development into high affinity antibody plasma cells in the germinal centre (Crotty 2011), implying that an increase of these cells could contribute to enhanced antibody production. This is in line with the IgG isotypes of IgG1 and IgG4 in AAV that implies that the antibody producing cells have received T cell help (Vidarsson et al. 2014). In the study by Aybar et al. they showed that both $\mathrm{IL}-10^{+} \mathrm{B}$ cells and $\mathrm{CD} 5^{+} \mathrm{CD} 24^{\text {high }} \mathrm{CD} 38^{\text {high }} \mathrm{B}$ cells inversely correlated with ANCA titre (Aybar et al. 2015), suggesting a role for these B cells in limiting antibody production. Thus dysregulation of these populations could be important for an altered antibody production. 
There is compelling evidence that NETs can act as a bridge between innate and adaptive immunity through the generation of pathogenic ANCA. One study in mice showed that injection of in vitro cultured mice myeloid DCs loaded with NET-derived MPO and PR3 resulted in MPO-ANCA and PR3-ANCA in the circulation and that the mice developed AAV-like disease (Sangaletti et al. 2012). PR3 and MPO uptake by myeloid DCs (mDCs) was abolished in the presence of DNaseI in the co-culture of $\mathrm{mDCs}$ and NETotic neutrophils. In line with the mouse study, a study in rats showed that PTU-induced NETs cause MPOANCA and inflammatory disease. Of note is that the drug PTU induces "abnormal" NETs that are resistant to DNaseI degradation. "Normal" NETs induced by PMA did barely cause ANCA production in this model and rats did not develop disease (Nakazawa et al. 2012). Importantly, two other observations in these studies deserve attention. 1) It appears that the structural integrity of NETs is important for transfer/uptake of NET-antigens, as addition of DNaseI (mouse model) or using NETs sensitive to degradation by DNaseI (rat model) did not generate any ANCA or reduced the production of ANCA, respectively. 2) In the first study (mouse model), injection of mDCs co-cultured with apoptotic neutrophils also caused ANCA production in the mice, but the mice did not develop disease. This suggests that NETs show higher immunogenicity than apoptotic neutrophils. The latter statement is also in line with an older study in rats showing that transfer of apoptotic cells indeed results in circulating ANCA, but the rats do not develop disease (Patry et al. 2001). Thus, both the above studies (mouse/rat) imply that prolonged exposure to the proteins in the NETs can lead to pathogenic ANCA production and disease. Hence, overproduction and/or reduced clearance of NETs could be important in AAV.

In line with this, it has been shown that patients have reduced capacity to degrade NETs in vitro and that they possess reduced DNaseI activity compared with HC (Nakazawa et al. 2014). This indicates that the elevated levels of NETs in patients also could be explained by a reduced capacity to clear NETs. 


\section{Aims}

The overall aim of this thesis was to increase our knowledge about the pathophysiology of $\mathrm{AAV}$, by investigating various immunological aspects. We wanted to investigate potential proinflammatory mechanisms by studying neutrophil activation and NET remnants in the circulation as well as to investigate B cell subpopulations involved in immune regulation and in maintaining homeostasis. Further, after finding that B cells can release ET-like structures, we wanted to elucidate whether they as well as other cells of lymphoid origin (T cells) are capable of releasing ETs, a feature so far only denoted to cells of myeloid origin. If so, we then wanted to investigate this signalling pathway as well as origin (nuclear/mitochondrial) of the DNA.

\section{Specific aims}

- The aim of paper I was to analyse NET remnants in the circulation of AAV patients with different degrees of disease activity and to elucidate possible factors responsible for variations in these remnants.

- The aim of paper II was to investigate the activation potential of neutrophils in AAV patients and to elucidate whether titers, epitope specificity or affinity influence the pathogenicity of ANCA.

- The aim of paper III was to investigate whether also B and T cells are capable of releasing extracellular traps of nuclear and/or mitochondrial origin resembling those described in different myeloid cells.

- The aim of paper IV was to investigate the frequency of MZ-like B cells and B1-like cells as well as of different proposed Breg cell populations $\left(\mathrm{CD} 24^{\text {high }} \mathrm{CD} 27^{+}\right.$, $\mathrm{CD} 25^{+} \mathrm{CD} 27^{+}$and $\mathrm{CD} 24^{\text {high }} \mathrm{CD} 38^{\text {high }} \mathrm{B}$ cells) in the circulation of AAV patients with different degrees of disease activity. We also wanted to characterize the phenotype of the proposed Breg cell populations. 


\section{Material and methods}

An overview of the different analytical methods used in papers I-IV is shown in Table II. In this section the methods used to obtain the main findings in paper I-IV are described and discussed, but details of all different methods employed can be found in the respective papers.

\section{Ethical considerations}

The studies in paper I, III and IV were approved by the Regional Ethical Review Board in Linköping and the study in paper II by the Ethical Review Board in Lund. Informed consent was obtained from each included patient and healthy control. Samples used in the different studies only constituted of blood samples. Components in plasma or readouts from in vitro experiments were correlated with clinical data. The laboratory data was handled by myself in a blinded fashion, without access to patient journals.

\section{Patients and controls}

All patients in Östergötland are listed in a data base containing clinical data of the patients. This data base is continuously updated, providing a well-characterized patient cohort (Eriksson et al. 2009). Only patients with GPA or MPA were investigated in the different papers of this thesis, diagnosed according to the EMA algorithm (Watts et al. 2007). All patients in remission had a BVAS of 0 . Healthy controls in these studies were matched with patients according to gender and age. More detailed study population characteristics can be found in the respective papers. 
Table II: Overview of the analytical methods used in paper I-IV

\begin{tabular}{|c|c|c|c|c|}
\hline Paper & $\mathbf{I}$ & II & III & IV \\
\hline \multicolumn{5}{|l|}{ Cell isolation } \\
\hline Neutrophils (density gradient centrifugation) & $\mathrm{x}$ & $\mathrm{x}$ & $\mathrm{x}$ & \\
\hline PBMC (density gradient centrifugation) & & & $\mathrm{x}$ & $\mathrm{x}$ \\
\hline $\mathrm{B}$ and $\mathrm{T}$ cells (FACS) & & & $\mathrm{x}$ & \\
\hline \multicolumn{5}{|l|}{ Microplate fluorescence reader } \\
\hline $\begin{array}{l}\text { Cell death assay: quantification } \\
\text { of NETosis/necrosis }\end{array}$ & $\mathrm{x}$ & $\mathrm{x}$ & $\mathrm{x}$ & \\
\hline
\end{tabular}

\section{Immunofluorescence and live cell imaging}

NETs (immunofluorescence)

X X

mtDNA webs (live cell imaging)

$\mathrm{X}$

\section{Cell viability}

LDH assay (cytotoxicity)

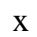

Viability, cytotoxicity and apoptosis

(Triplex Assay)

\section{Antibody purification}

IgG $x$

\section{ELISA}

NET remnants (DNA + MPO complexes)

$\mathrm{X}$

PR3 and MPO-ANCA

$\mathrm{X}$

Neutrophil degranulation

$\mathrm{X} \quad \mathrm{X}$

IgG affinity for PR3

$\mathrm{X}$

Luminex

IL-1 $\beta$, IL-6, IL-10, TNF and IFN- $\alpha 2$

$\mathrm{X}$

Flow cytometry

Cell surface expression of PR3 on neutrophils

Mitochondrial superoxide in B cells and

$\mathrm{X}$

neutrophils

B cell frequencies and phenotypes in blood

\section{ROS assay}

Neutrophils

B cells

\section{Bacterial cultures}

Bacteria + mtDNA webs to evaluate toxicity of mtDNA webs

\section{Gel electrophoresis}

Quantification of NETs and mtDNA webs

\section{DNA sequencing and PCR}

NETs and mtDNA webs 


\section{Experimental procedures}

\section{Cell isolation procedures}

\section{Neutrophils}

Peripheral whole blood was drawn into EDTA-treated tubes and centrifuged. The buffy coat containing PBMC and neutrophils was collected and placed on top of layers of $63 \%$ and $72 \%$ percoll. After another centrifugation, neutrophils were collected from the interphase between the $63 \%$ and $72 \%$ percoll gradient. Red blood cells passed through the gradient and PBMC was present on top of the $63 \%$ percoll layer. From this step, neutrophils were handled on ice as they are easily activated. Hypotonic lysis was performed to remove any further contaminating red blood cells.

\section{PBMC}

Peripheral whole blood was drawn into heparin-treated tubes. The blood was diluted 1:2 in RPMI 1640 and layered on Ficoll before centrifugation. After centrifugation, PBMC were be collected from the interphase, whereas red blood cells and neutrophils passed through the Ficoll to the bottom of the tube. For paper III, PBMC were used directly to separate B and T cells but in paper IV they were stored in liquid nitrogen $\left(-190^{\circ} \mathrm{C}\right)$ for subsequent flow cytometry analyses. Before being placed in liquid nitrogen, PBMC were resuspended in freezing medium, placed in a freezing container "Mr Frosty" and stored in $-70^{\circ} \mathrm{C}$ for $24-48$ hours. "Mr Frosty" allows the temperature to decrease by only one degree per minute to retain cell viability.

\section{$B$ and $T$ cells}

For HC, total B cells were isolated from PBMC with magnetic activated cell sorting (MACS). This procedure was performed on ice to limit cell activation. With MACS, cells can either be positively or negatively selected. Magnetically labelled microbeads targeting the antigen/-s of interest are allowed to bind to cells in the sample. When cells pass through a MACS column that is placed near a magnet, only cells labelled with magnetic microbeads will be retained in the MACS column (i.e. positive selection) while the rest of the (non-magnetic) cells pass through the column (i.e. negative selection). The positively selected cells can be obtained if removing the MACS column from the magnet and then rinse the column. 
In the case of B cells from $\mathrm{HC}$, they were positively selected using anti-CD19 microbeads whereas the remaining PBMC were negatively selected. Then, different B cell subpopulations (naïve; $\mathrm{CD} 20^{+} \mathrm{CD} 27^{-}$, memory; $\left.\mathrm{CD} 20^{+} \mathrm{CD} 27^{+}\right)$and total $\mathrm{T}$ cells $\left(\mathrm{CD} 3^{+}\right.$cells) were isolated with fluorescence activated cell sorting (FACS), described in more detail in the section of flow cytometry. For CLL patients, $\mathrm{PBMC}$ were isolated as for $\mathrm{HC}$ but then $\mathrm{CD}^{+} \mathrm{B}$ cells were negatively selected using MACS separation.

\section{Cell death assay}

A cell death assay previously also used by others (Brinkmann et al. 2004, Gupta et al. 2010, Gray et al. 2013, Seper et al. 2013) was employed in a similar fashion to quantify the rate of NETosis and release of NETs in neutrophils from AAV patients (GPA and MPA) (paper I) and HC (paper I-III). The cell-impermeable dye Sytox Green, which fluoresces at $523 \mathrm{~nm}$ when bound to DNA (with excitation at $504 \mathrm{~nm}$ ), was used to stain extracellular DNA, but does also stain DNA intracellularly in cells with a ruptured membrane (i.e. necrotic cells). However, visualization of NETs with immunofluorescence by us and others has shown that the neutrophils primarily undergo NETosis when stimulated with PMA and it has been shown that these two assays correspond well to each other upon PMA stimulation (Gray et al. 2013, Seper et al. 2013). It has also been shown that the other stimulus used by us in paper I and II, TNF and ANCA, can induce NETosis (Kessenbrock et al. 2009, Keshari et al. 2012), but also that NETosis can occur spontaneously in unstimulated neutrophils (Sur Chowdhury et al. 2014, Tang et al. 2015). Although one cannot exclude that also necrotic cells are being stained with this method, it is beneficial that no NETs are being lost during the measurements. This is particularly important for unstimulated neutrophils where only a fraction of the cells stain positive for Sytox Green. In contrast to this approach, immunofluorescence experiments (explained later) contains many washing steps (which instead is favourable for visualization of NETs). A standardisation of the different methods used to quantify NETosis and release of extracellular DNA is important for comparisons between studies and should be further evaluated. 
In paper I, neutrophils were resuspended in rosewell park memorial institute (RPMI) supplemented with L-glutamine and $0.5 \%$ fetal bovine serum (FBS) and 50000 neutrophils were seeded onto a 96 well plate and allowed to adhere for $30 \mathrm{~min}$ at $37^{\circ} \mathrm{C}$. Then, neutrophils were stimulated with TNF ( $8 \mathrm{ng} / \mathrm{ml})$, phorbol 12-myristate 13 -acetate (PMA) (10 nM), 1\% Triton X-100 or were left unstimulated in the presence of Sytox Green $(2.5 \mu \mathrm{g} / \mathrm{ml})$ to stain DNA. The plate was then monitored hourly for 4 hours and read at $523 \mathrm{~nm}$ in a fluorescence plate reader. Triton X-100 was used to get a $100 \%$ DNA reference value (total DNA) and the results are expressed as percentage of total DNA.

In paper II, neutrophils were cultured as in paper I but in 2\% FBS. After 30 minutes of incubation to adhere, they were primed with $2 \mathrm{ng} / \mathrm{ml}$ TNF for 15 minutes. Neutrophils were then incubated with $\mathrm{IgG}$ antibodies, at $200 \mathrm{ug} / \mathrm{ml}$, isolated from 10 different PR3-ANCA positive patients with varying disease activity (same as used for ROS detection in paper II) or with healthy control IgG (Beriglobin) as a negative control in the presence of Sytox Green. PMA was used as a positive control. The plate was then monitored hourly for 7 hours and read at $523 \mathrm{~nm}$ in a fluorescence plate reader.

In paper III, neutrophils were used to evaluate a variety of inhibitors for $\mathrm{CpG}-\mathrm{C}$ induced web formation. Neutrophils were cultured as in paper I but in $2 \%$ FBS. After 30 minutes of incubation, neutrophils were stimulated with $20 \mathrm{nM}$ PMA for $4 \mathrm{~h}$ after a $1 \mathrm{~h}$ pre-incubation with various inhibitors. Release of NETs was measured and analysed as in paper I. 


\section{Immunofluorescence of NETs and live cell imaging of DNA webs}

Immunofluorescence is a technique used to visualize structures by fluorescence microscopy (Beutner 1961). A fluorochrome-conjugated antibody is allowed to bind to the antigen (or to a primary antibody directed towards the antigen). The fluorochrome is then excited by a light source at a specific wave length for the particular fluorochrome in a fluorescence microscope. The fluorochrome in turn emits light (fluorescence) that is detected and visualized. If fluorescence at different wavelengths can be detected by the microscope, several targets can be investigated simultaneously. Molecules either on the cell surface or intracellularly can be labelled if the cell membrane is lysed and the cells are fixed. We used this technique in paper II with the purpose to investigate whether neutrophils can release NETs spontaneously, by defining NETs as co-localization of DNA (the backbone of NETs) and NE (protein present in NETs).

Neutrophils were resuspended in $0.5 \%$ FBS and cultured on $0.001 \%$ Poly-L-lysine coated coverslips. Cells were allowed to adhere for 30 minutes at $37^{\circ} \mathrm{C}$ before being stimulated with 10nM PMA or left unstimulated for 4 hours and then fixed with $4 \%$ paraformaldehyde. Due to the fragile nature of NETs, which are easily washed away, the coverslips were placed upside down on drops of PBS during washing or drops of antibody solution during antigen staining. Each coverslip was incubated with an antibody towards NE (primary antibody) for 1 hour in room temperature before addition of an Alexa 488-flurochrome conjugated antibody (secondary antibody) (excitation; $488 \mathrm{~nm}$, emission; $523 \mathrm{~nm}$ ) targeting the NE-specific antibody for another hour. The coverslips were then mounted onto slides using small drops of ProLong gold anti-fading mounting media that contained DAPI (which stains DNA). The coverslips were left for 24 hours to cure before being analysed by fluorescence microscopy.

DNA webs observed upon stimulation with $\mathrm{CpG}-\mathrm{C}$ and $\mathrm{GpC}-\mathrm{C}$ were even more fragile than classical NETs and could not be visualized through immunofluorescence on coverslips. Instead, DNA webs were visualized directly in the wells they were cultured in and were defined as Sytox Green positive structures. In these experiments, 300000 neutrophils, various B cell subpopulations and T cells were cultured in 48-well plates in RPMI containing $2 \%$ FBS for 5 minutes to 4 hours with different stimuli. When inhibitors were used, cells were pre-incubated with those for $1 \mathrm{~h}$ before stimulation. Then, Sytox Green was added to each well, before the presence of DNA webs was evaluated directly in the 48-well plates with a fluorescence microscope. 


\section{NET remnant ELISA}

In paper I, we used enzyme-linked immunosorbent assay (ELISA) to measure the presence of NET remnants in the circulation of AAV patients (GPA and MPA) and HC. We adopted the definition of NET remnants as complexes of nucleosomes and MPO (Kessenbrock et al. 2009). It could be discussed in general whether autoantibodies in the circulation could interfere with ELISA. An idea could be to measure different complexes of proteins and autoantibodies depending on the patient group and their repertoire of autoantibodies. We did, however, not observe any significant differences in the levels of NET remnants in patients with MPO-ANCA or PR3-ANCA. When others have tried to define NETs as DNA/PR3 complexes with ELISA they only found NETs in some of the patients compared with MPO/DNA complexes, indicating that PR3 could be less tightly bound to the NETs, and therefore less suitable to be used in ELISA (Surmiak et al. 2016). In AAV, for example NE could be a good choice to evaluate for NET remnant ELISA as it is also highly present in NETs, whereas ANCA towards NE is uncommon.

We coated a 96-well plate with a monoclonal mouse anti-nucleosome antibody (B6.SLE-1) at $4^{\circ} \mathrm{C}$ overnight. To be able to quantify NET remnants, as there are no commercial standards for NET remnants yet, we created a standard curve from a plasmapheresis sample from a AAV patient with high levels of DNA/MPO complexes. Samples and standard were incubated in room temperature for 1.5 hours. During this time, only structures containing nucleosomes will bind to the coated antibodies. Thereafter, an antibody against MPO was added and incubated for 1 hour. The plate was washed to remove all unbound MPO. Then, an alkaline-phosphatase antibody against the anti-MPO antibody was added. This antibody was also allowed to bind for 1 hour before addition of a substrate for alkaline-phosphatase, which turns yellow if both substrate and alkaline-phosphatase are present in the wells. Absorbance, as a measure of the presence of NET remnants in the wells, was measured at $405 \mathrm{~nm}$ in a microplate reader. 


\section{ROS detection}

In paper II, we measured intracellular and extracellular ROS production in neutrophils from PR3-ANCA positive patients and HC after stimulation with purified IgG from PR3-ANCA positive patients with varying disease activity. We used a method relying on the reaction of ROS with luminol and isoluminol, referred to as chemiluminescence (Lundqvist and Dahlgren 1996). Luminol but not isoluminol can pass intact cell membranes, but both compounds emit light (luminescence) after reacting with ROS, which can be measured in a microplate reader. When we wanted to detect ROS intracellularly, we used luminol in combination with the ROS scavenger catalase and SOD to remove extracellular ROS, as luminol can be present both within and outside the cell. However, to detect ROS extracellularly, isoluminol was used in the absence of any scavenger.

Neutrophils were cultured in 96-well plates, primed with TNF for 15 minutes and then Cytochalasin B for 5 minutes, both at $37^{\circ} \mathrm{C}$. They were then incubated with the $\operatorname{IgG}$ antibodies, at 200ug/ml, a monoclonal PR3 antibody, PMA (as a positive control) or with PBS as a negative control. Neutrophils were stimulated for 70 minutes and luminescence (as a measure of ROS production) was monitored in a microplate reader.

\section{Flow cytometry}

Flow cytometry is an extensively used method to determine frequencies of different cellular populations, cell viability, DNA content and cell proliferation (Picot et al. 2012). As basic measurements, cell size and granularity can be determined, where forward scatter (FSC) is proportional to the cell size and side scatter (SSC) to the granularity of the cell. FSC and SSC can together be used for identification of different cell populations; lymphocytes are relatively small and non-granular, whereas monocytes are larger (increased FSC) with higher granularity (SSC). Further, granulocytes show even higher granularity and can be clearly distinguished from other cells according to FSC. Also, dead cells can be roughly distinguished due to their smaller size than their corresponding live populations. 
Molecules either on the cell surface or intracellularly can be studied though labelling with fluorochrome-conjugated antibodies. Once a cell passes the lasers, fluorochromes present on the cells will be excited and the emitted light (fluorescence) is registered by detectors (photomultiplier tubes (PMTs)). PMTs detect and amplify the light signal, which is then digitalized and can be analysed with a specific computer software. Such a signal from one cell is referred to as an "event". For example, a population of cells (or "events") expressing the same molecule can then be "gated" out to investigate that particular population further (for example calculate the percentage of these cells within all cells or some other population). Since a single cell might be stained with several different fluorochrome-conjugated antibodies, light of different wavelengths is split using dichroic mirrors allowing fluorescence signals to be recorded separately. However, as fluorochromes have relatively broad emission spectrums, fluorescence signals to various extents leaks into multiple detectors. This is referred to as spectral overlap and is important to consider. Therefore, fluorochromes with low spectral overlap should be considered if possible when designing an experiment. However, fluorescence that leaks into a wrong channel can be quantified and compensated for by subtracting the percentage of the leaked signals from the signal of interest.

A technique based on flow cytometry is fluorescence activated cell sorting (FACS) that allows "gated" populations to be isolated (sorted) into test tubes. Sorting is possible through generation of droplets, with each droplet containing one cell. Drops that contain cells from the "gated" population (population of interest) are allocated an electrical charge. All droplets pass an electrical field generated by deflection plates, and droplets given a charge in contrast to droplets without a charge are pulled towards the plates and fall into collection tube whereas uncharged droplets continue into a waste tube.

Important in flow cytometry as well as during cell sorting is the use of experimental controls, such as isotype controls and/or fluorochrome minus one (FMO) controls to be able to determine whether an "event" is truly positive or not for a specific molecule. Another option is to use a cell population with the sample that is known to not express the molecule of interest as a negative control population. 
In paper IV, 8-colour flow cytometry was employed to investigate the frequency of MZ-like B cells, B1-like B cells and various proposed Breg cell populations with the phenotypes $\mathrm{CD} 24^{\text {high }} \mathrm{CD} 27^{+}, \mathrm{CD} 25^{+} \mathrm{CD} 27^{+}$and $\mathrm{CD} 24^{\text {high }} \mathrm{CD} 38^{\text {high }}$. We also phenotyped the different Breg cell populations. MZ-like B cells were defined as $\mathrm{CD} 27^{+} \operatorname{IgD}^{+} \operatorname{IgM}^{\text {high }}$ and B1-like B cells as $\mathrm{CD} 20^{+} \mathrm{CD} 27^{+} \mathrm{CD} 43^{+} \mathrm{CD} 70^{-} \mathrm{B}$ cells. As CD43 is also expressed on $\mathrm{T}$ cells, contamination of $\mathrm{CD}^{+}$cells could appear in the gate for B1-like B cells (Griffin et al. 2011). We therefore included CD3 in the gating strategy for this population. PBMC were thawed in a $37^{\circ} \mathrm{C}$ water bath before washed in RPMI $1640+10 \%$ FBS two times. The cells were resuspended in PBS $+0.1 \%$ FBS before labelling of surface molecules with antibodies according to the three different flow cytometry panels used in this study (Table III). FMO-controls or FMO + isotype-controls were used to set appropriate gates to determine positivity for a specific surface molecule. There were no differences between fresh and frozen samples with respect to the surface molecules investigated in this study.

Table III: Flow cytometry panels

\begin{tabular}{|l|l|l|l|l|l|l|l|l|}
\hline & $\begin{array}{l}\text { FITC } \\
\text { (FL1) }\end{array}$ & $\begin{array}{l}\text { PE } \\
\text { (FL2) }\end{array}$ & $\begin{array}{l}\text { PerCP- } \\
\text { y5.5 (FL4) }\end{array}$ & $\begin{array}{l}\text { PE-Cy7 } \\
\text { (FL5) }\end{array}$ & $\begin{array}{l}\text { APC } \\
\text { (FL6) }\end{array}$ & $\begin{array}{l}\text { APC- } \\
\text { Cy7 } \\
\text { (FL8) }\end{array}$ & $\begin{array}{l}\text { BV421 } \\
\text { (FL9) }\end{array}$ & $\begin{array}{l}\text { HV500 } \\
\text { (FL10) }\end{array}$ \\
\hline$\# 1$ & $\begin{array}{l}\text { CD19 } \\
\text { Clone: } \\
\text { HIB19 }\end{array}$ & $\begin{array}{l}\text { CD27 } \\
\text { O323 }\end{array}$ & $\begin{array}{l}\text { CD24 } \\
\text { ML5 }\end{array}$ & $\begin{array}{l}\text { CD86 } \\
\text { IT2.2 }\end{array}$ & $\begin{array}{l}\text { IgM } \\
\text { MHM-88 }\end{array}$ & x & $\begin{array}{l}\text { CD38 } \\
\text { HIT2 }\end{array}$ & $\begin{array}{l}\text { IgD } \\
\text { IA6-2 }\end{array}$ \\
\hline$\# 2$ & $\begin{array}{l}\text { CD19 } \\
\text { HIB19 }\end{array}$ & $\begin{array}{l}\text { CD273 } \\
\text { MIH18 }\end{array}$ & $\begin{array}{l}\text { CD24 } \\
\text { ML5 }\end{array}$ & $\begin{array}{l}\text { CD86 } \\
\text { IT2.2 }\end{array}$ & $\begin{array}{l}\text { CD25 } \\
2 A 3\end{array}$ & $\begin{array}{l}\text { CD27 } \\
\text { O323 }\end{array}$ & $\begin{array}{l}\text { CD274 } \\
\text { 29E.2A3 }\end{array}$ & $\begin{array}{l}\text { IgD } \\
\text { IA6-2 }\end{array}$ \\
\hline$\# 3$ & $\begin{array}{l}\text { CD43 } \\
\text { MEM-5 }\end{array}$ & $\begin{array}{l}\text { CD70 } \\
\text { Ki-24 }\end{array}$ & $\begin{array}{l}\text { CD27 } \\
\text { O323 }\end{array}$ & $\begin{array}{l}\text { CD19 } \\
\text { HIB19 }\end{array}$ & $\begin{array}{l}\text { CD25 } \\
2 A 3\end{array}$ & $\begin{array}{l}\text { CD20 } \\
\text { L27 }\end{array}$ & $\begin{array}{l}\text { IgD } \\
\text { IA6-2 }\end{array}$ & $\begin{array}{l}\text { CD3 } \\
\text { UCHT1 }\end{array}$ \\
\hline
\end{tabular}

FITC, fluorescein isothiocyanate; PE, phycoerythrin PerCP, peridinin-chlorophyll-protein; Cy5.5, cyanin5.5; Cy7, cyanin7; APC, allophycocyanin; BV421, Brilliant Violet 421; HV500, Horizon V500 


\section{LDH cytotoxicity (viability) assay}

Lactate dehydrogenase (LDH) is an enzyme that is present in all cells. LDH is rapidly released from the cells when the plasma membrane is damaged, and can thus be used as a quantitative method for cell deaths associated with a ruptured membrane. LDH activity is determined in a coupled enzymatic reaction where the tetrazolium salt INT is reduced to formazan. The formazan dye has an absorption maximum at approximately $500 \mathrm{~nm}$ and can be measured with a microplate reader.

In paper III, we used this method to evaluate whether cells upon CpG-C stimulation release DNA webs independent of cell death or not. Cells were seeded at a density of $2 \times 10^{6}$ cells $/ \mathrm{ml}$ and treated with PMA or CpG-C for $4 \mathrm{~h}$. The supernatants were collected, centrifuged to remove cells and then incubated with the substrate mixture from the kit before analysed in a microplate reader.

\section{PCR}

Polymerase chain reaction (PCR) is a technique used to make multiple copies of a sequence of DNA (Mullis and Faloona 1987). It is possible to decide which genetic sequence to amplify by using specific primers to define that sequence. By also adding nucleotides that serve as building blocks of DNA as well as a DNA polymerase, which will build new DNA strands of the available nucleotides, into the reaction, multiple copies of a desired DNA sequence can be amplified.

In paper III, we used PCR to amplify DNA sequences of the released DNA webs from neutrophils, B and T cells after stimulation, but also total DNA, to investigate whether the released DNA was of nuclear or mitochondrial origin. After stimulation of cells, DNA webs were collected and run on a $0.8 \%$ agarose gel with $100 \mathrm{~V}$ for $2 \mathrm{~h}$. The characteristic DNA fragment on the gel was removed and DNA was purified. For the detecting of nuclear and mitochondrial DNA, we used primers that had previously been used for this purpose on NETs (Yousefi et al. 2009). We used primers towards the mitochondrially encoded genes NADH dehydrogenase subunit $1(\mathrm{Nd} 1)$, cytochrome oxidase c subunit 1 (Co1) and cytochrome oxidase $\mathrm{b}(\mathrm{Cyb})$ and primers towards the nuclear encoded genes Fas, Rhoh and Actb. The different PCR products were then run on a gel as described above to compare the mplification of nuclear and mitochondrial genes in the released DNA webs and of total DNA. 


\section{Statistical methods}

Details for the statistical methods used are provided in each paper. However, all data were analysed using GraphPad Prism, version 6.0a (paper II) or 6.02 (paper I, II and IV)

(GraphPad Software, San Diego, CA, USA). D’Agostino and Pearson omnibus normality test was used to determine whether the data had a Gaussian distribution or not. If the data had a Gaussian distribution, a t-test was used when comparing two groups and one-way analysis of variance followed by Tukey's multiple comparison test for comparisons of more than two groups with independent observations. For data with a non-Gaussian distribution, MannWhitney U test was used when comparing two groups and the Kruskal-Wallis test followed by Dunn's multiple comparison test for comparisons of more than two groups with independent observations. In the case of log-normal data, the data was log-transformed before being analysed. All correlation analyses were performed with Spearman's rank correlation coefficient $\left(\mathrm{r}_{\mathrm{s}}\right)$ as at least one of the variables analysed had a non-Gaussian distribution. $P$ values $<0.05$ were considered statistically significant in all analyses $(* P<0.05$, ** $P<0.01$, *** $P<0.001$, **** $P<0.0001)$. 


\section{Results and discussion}

\section{Paper I}

In this study we hypothesized that AAV patients would have elevated levels of NET remnants in the circulation and that neutrophils from patients would be more prone to undergo NETosis/necrosis. To evaluate these parameters, we measured NET remnants in plasma samples from 69 patients in remission, 24 patients with active disease and 34 HC. For 10 patients we collected samples both during remission and active disease and performed matched comparisons. Levels of NET remnants were correlated with ANCA titres, spontaneous and induced cell death (NETosis/necrosis) in vitro, neutrophil count and corticosteroid therapy to learn more about the factors that could affect circulating NET remnants.

\section{Increased levels of NET remnants in the circulation during active disease}

We observed NET remnants to be elevated in AAV patients with active disease compared with patients in remission and HC (Fig. 4A). When comparing the levels of NET remnants in the same patients during remission and active disease, the levels were increased for all patients during active disease (Fig. 4B). Our results are in line with some other studies also defining NETs as nucleosome and MPO complexes (Kessenbrock et al. 2009, Surmiak et al. 2016), although one study could not show this (Wang et al. 2016). Although we and others have measured NET remnants at two occasions (active and remission), the potential to use NET remnants as a biomarker to monitor disease activity demands longitudinal studies with multiple measurements, which have not yet been performed. 
In line with our results, NET-associated components such as NE, calprotectin, HMGB1 and MPO have also been shown to be elevated in the circulation of AAV patients compared with $\mathrm{HC}$, and some of them have also bene elevated during active disease compared with remission (Soderberg and Segelmark 2016). Although infections can induce NET formation, we could not find a correlation with CRP in patients with active disease, suggesting that infections and NET formation in these patients to some extent represent separate or partly overlapping pathogenic routes.

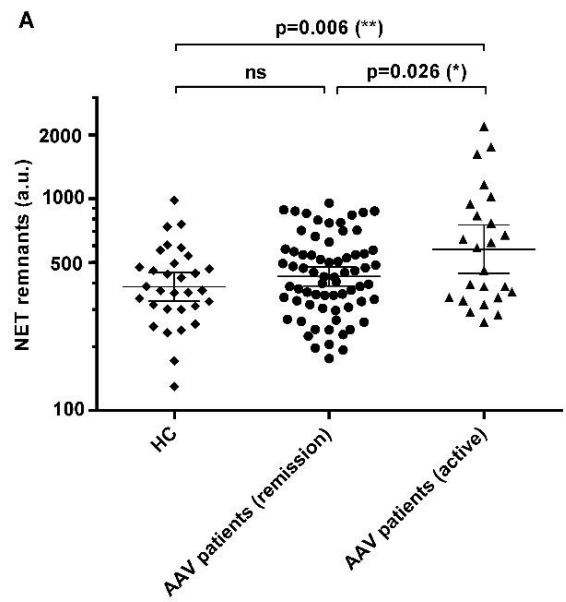

B

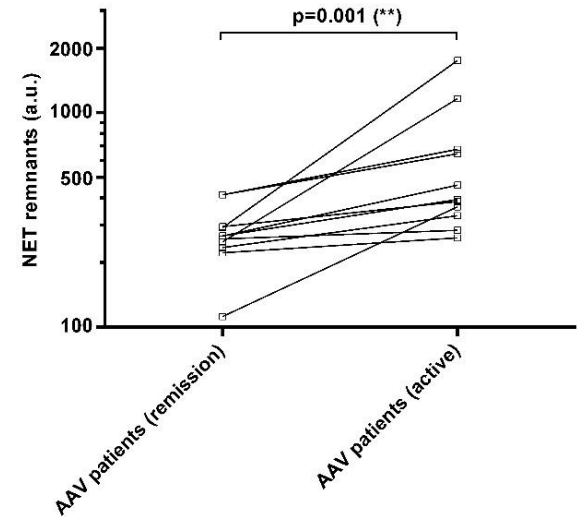

Figure 4. Circulating NET remnants. (A) Patients with active disease possessed elevated levels of NET remnants in the circulation compared with patients in remission and HC. (B) During matched observations of patient samples taken during both remission and active disease, NET remnants were higher during active disease in all patients. $* \mathrm{P}<0.05$, $* * \mathrm{P}<0.01$. 


\section{Enhanced spontaneous NETosis/necrosis in patients}

In paper I, we also observed an increased rate of spontaneous NETosis/necrosis in AAV patients compared with HC (Fig. 5A). This was also true after excluding patients with active disease (open triangles). Members in our group have previously observed a reduced rate of apoptosis in neutrophils from patients (Abdgawad et al. 2012), suggesting that they are more prone for other forms of cell death, which is in line with our present finding. When stimulating neutrophils with TNF of various concentrations (Fig. 5B-C) there were no longer any differences between the groups. Neutrophils were also stimulated with PMA and almost all cells underwent NETosis/necrosis (Fig. 5D). Thus, we think that an explanation for the increased rate of spontaneous cell death observed in unstimulated neutrophils from patients could depend on the environment from which the neutrophils were isolated. Patients with AAV also during remission possess increased levels of several cytokines in the circulation and neutrophils show altered intracellular cytokine expression (Ohlsson et al. 2004, Hruskova et al. 2009, Nogueira et al. 2010). However, only some of these cytokines are connected to NETosis (such as TNF-a) (Fuchs et al. 2007, Keshari et al. 2012, Khandpur et al. 2013).
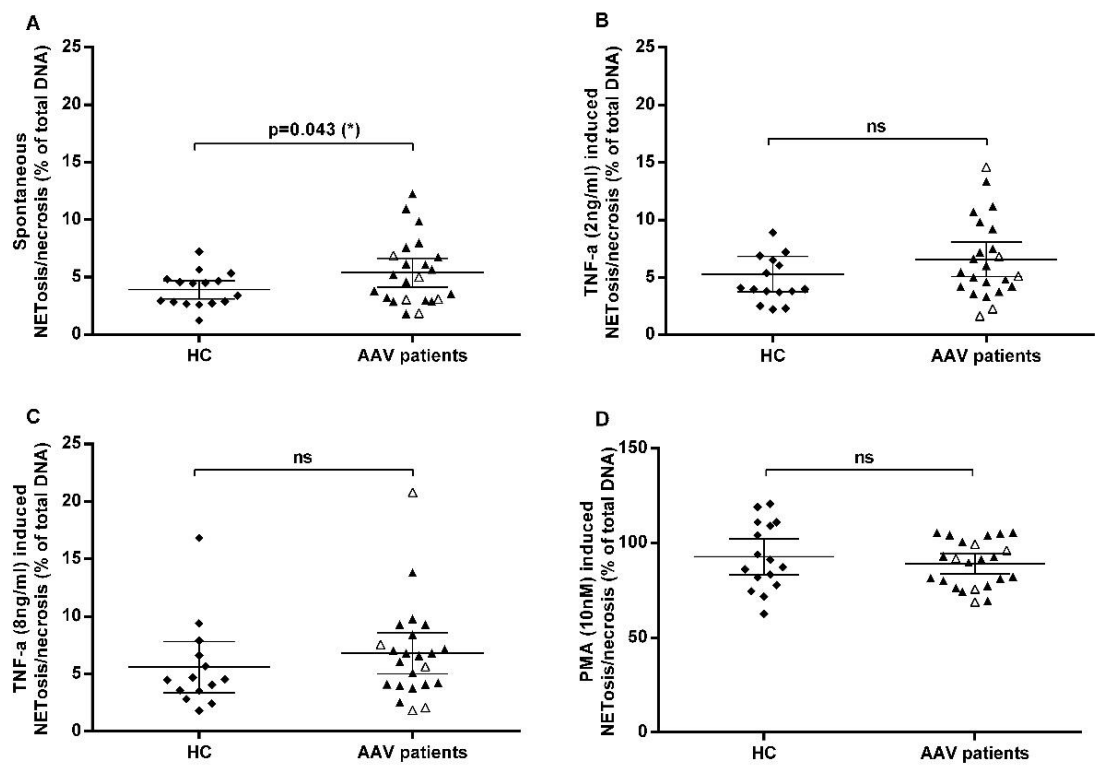

Figure 5. NETosis/necrosis. (A) AAV patients showed an increased rate of spontaneous NETosis/necrosis compared with HC, but this was abolished upon stimulation with (B-C) TNF or (D) PMA. The results are expressed as percentage of total DNA (lysis of cells with $1 \%$ Triton X-100) and reflect the increase in cell death over 4 h. $* \mathrm{P}<0.05$. 
In addition to an effect of cytokines, ANCA could also have activated the neutrophils before isolation. Another explanation could be due to the aberrant gene expression of PR3 and MPO observed in AAV patients (Ciavatta et al. 2010). As MPO has been shown to be important in the signalling pathway of NETosis (Papayannopoulos et al. 2010), increased availability of MPO could possibly facilitate an increased spontaneous rate of NETosis. Treatment did not correlate with the rate of spontaneous cell death (data not shown).

\section{Inverse correlation between NET remnants and PR3-ANCA during remission}

When trying to explain the variation of NET remnants in paper 1, we found a negative correlation between PR3-ANCA and NET remnants in patients in remission $\left(\mathrm{r}_{\mathrm{s}}=0.287\right.$, $P=0.048$ ). The pathogenicity of ANCA vary during active disease and remission where reduced capacity to induce ROS and NETs is found during remission (Roth et al. 2013, Nakazawa et al. 2014, Yoshida et al. 2016). Our finding suggests a dual role for ANCA of which some also are involved in clearance of NET remnants from the circulation, possibly through opsonization. We have previously also reported on an inverse relationship between ANCA and PR3/ $\alpha 1$-antitrypsin complexes in the circulation (Ohlsson et al. 2003).

When correlating NET remnants with spontaneous NETosis/necrosis, we could see that patients with high levels of NET remnants tended to have an increased rate of spontaneous cell death although this was not significant $\left(\mathrm{r}_{\mathrm{s}}=0.2727, P=0.2080\right)$. We did, however, find a positive correlation for NET remnants with neutrophil count, but only in $\mathrm{HC}\left(\mathrm{r}_{\mathrm{s}}=0.503\right.$, $P=0.014$ ), suggesting that other factors such as increased cell death and/or altered clearance of NETs affect this correlation. Most patients were treated with immune modulatory therapy but no correlation was found between with the levels of NET remnants and therapy (data not shown). 


\section{Paper II}

To compare whether neutrophils from AAV patients were more easily activated by ANCA, we isolated neutrophils from five patients with GPA and five $\mathrm{HC}$ and stimulated them with purified IgG from 10 different GPA patients with varying disease activity. We hypothesized that neutrophils in patients would be more easily activated than those in HC.

\section{Neutrophils from patients are more easily activated by ANCA}

We observed that neutrophils from AAV patients in remission were more easily activated by ANCA than neutrophils from HC with respect to intracellular ROS production (Fig. 6A-B). We did, however, not observe any differences in the levels of extracellular ROS production or degranulation. The reason for patient neutrophils being more easily activated by ANCA could be as discussed in paper as the neutrophils also during remission are isolated from a more proinflammatory milieu (Ohlsson et al. 2004, Hruskova et al. 2009, Nogueira et al. 2010). As ANCA activate neutrophils through PR3 and MPO on the cell surface, altered PR3 membrane expression could have been a possibility for an altered activation potential. We could, however, not confirm previous findings of increased PR3 cell surface expression in AAV (Csernok et al. 1994, Witko-Sarsat et al. 1999) (HC; 63\% and AAV; 67\%).

a)

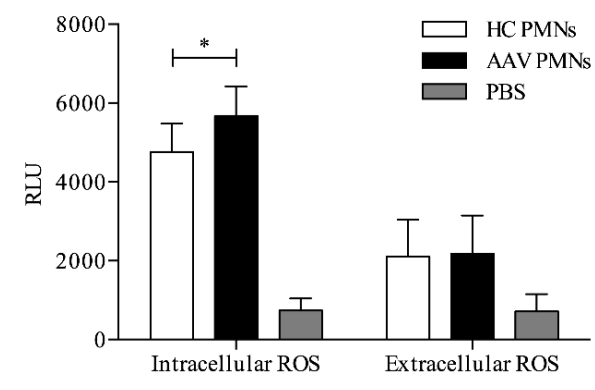

b)

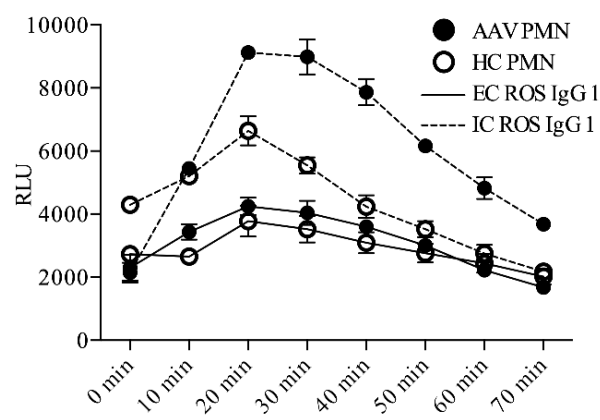

Figure 6. Neutrophil ROS production. (A) Neutrophils from patients $(n=5)$ showed increased levels of intracellular ROS production compared with $\mathrm{HC}(n=5)$ after 20 minutes of incubation with purified IgG $(200 \mu \mathrm{g} / \mathrm{ml})$ from 10 different GPA patients. (B) ROS was measured over time to show the kinetics of ANCA stimulation. Intracellular ROS production was higher in patients at every time point between 20-70 minutes. $* \mathrm{P}<0.05$. 
We also compared the functional abilities of the ten different ANCA preparations to stimulate ROS, degranulation and NETosis/necrosis. We found a strong correlation between ROS and NETosis/necrosis for the various isolated ANCA (intracellular ROS: $\mathrm{r}_{\mathrm{s}}=0.733, P=0.031$ and extracellular ROS: $\left.\mathrm{r}_{\mathrm{s}}=0.750, P=0.026\right)$. This was not surprising as ROS and NET formation often is related to each other (Stoiber et al. 2015). Finally, we could not see that corticosteroid treatment had any effect on our results. Corticosteroids rather reduce ROS production in neutrophils (Dandona et al. 1999).

\section{Affinity important for ANCA activation of neutrophils}

To be able to better compare the activation ability of ANCA in paper II, an activation score was calculated for each PR3-ANCA preparation as a mean value of their activation potential according to the different functional assays (ROS, degranulation and NETosis/necrosis). We then measured ANCA affinity and epitope specificities. ANCA levels in serum had already been measured at time of sampling from the patients from whom $\mathrm{IgG}$ was isolated. Affinity of PR3-ANCA correlated with the ANCA activation score $\left(\mathrm{r}_{\mathrm{s}}=0.758, \mathrm{P}=0.015\right)$, similar to reports of affinity of MPO-ANCA regarding their activation potential on NET formation (Nakazawa et al. 2014, Yoshida et al. 2016). It was recently shown that also epitope specificity correlated with the activation potential for MPO-ANCA and disease activity, with respect to ROS production (Roth et al. 2013). A certain epitope on PR3 has also been suggested to be pathogenic in GPA (Kuhl et al. 2010, Silva et al. 2010). We included this epitope in our study and confirmed that certain epitopes are more important, as we observed epitope specificity to be related to degranulation of lactoferrin and gelatinase. 


\section{Paper III}

We serendipitously observed NET-like structures protruding from B cells in co-cultures with neutrophils. Hence, we started to investigate whether B cells also could release ETs. We studied this phenomenon in B cells from CLL patients and HC, as well as in B cell lines. We also determined if $\mathrm{T}$ cells and different B-cell populations could release these structures.

\section{$B$ and $T$ cells can release mtDNA as ET-like structures (webs)}

We found that B cells (Fig. 7) and T cells can release ET-like structures in response to stimulation with CpG-C and GpC-C. This could be observed already after 5 min of stimulation. We first observed these structures in B cells from CLL patients but observed similar structures when expanding the analysis to $\mathrm{CD}^{+} \mathrm{B}$ cells as well as naïve and memory B cells from HC. This is a novel and previously unrecognized lymphocyte feature, similar structures have previously only been observed in cells of the myeloid lineage (Goldmann and Medina 2012).

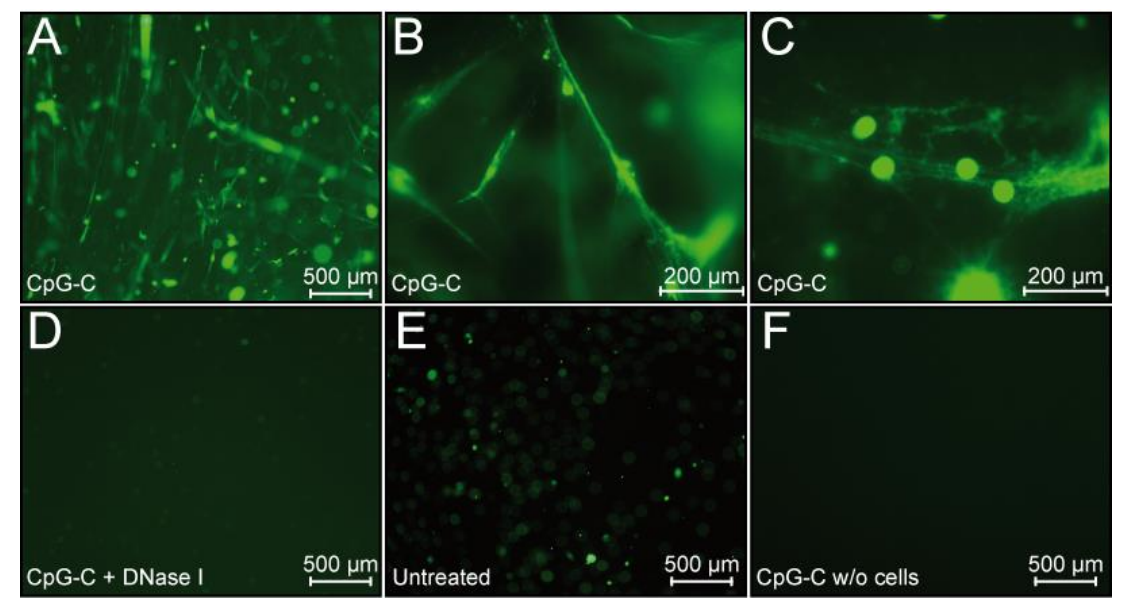

Figure 7. Visualization of DNA webs. (A-C) CpG-C induce B cells to release DNA, defined as extracellular Sytox Green positive structures (green areas). (D) When treating released DNA with DNaseI (which degrades DNA) the structures disappear. (E) Unstimulated B cells only released very little extracellular DNA. (F) As CpG-C is DNA itself it is relevant to see how this stain alone with Sytox Green. CpG-C in cell culture medium without cells only shows a smear, not at all similar to when cells are present and stimulated by CpG-C. 
In contrast to ETs previously described, we could not observe any antimicrobial capacity or any antimicrobial proteins in these structures, and therefore chose to use the term web instead of trap. In addition to $\mathrm{CpG}-\mathrm{C}$ and $\mathrm{GpC}-\mathrm{C}$ we tested a great variety of stimuli known to activate B cells (such as anti-IgM antibodies) and induce ETs (such as PMA, LPS, and TNF). None of those stimuli induced B cell webs (Fig. 8A). Both DNA sequencing and PCR (Fig. 8B) showed that the DNA in the webs was of mitochondrial origin.

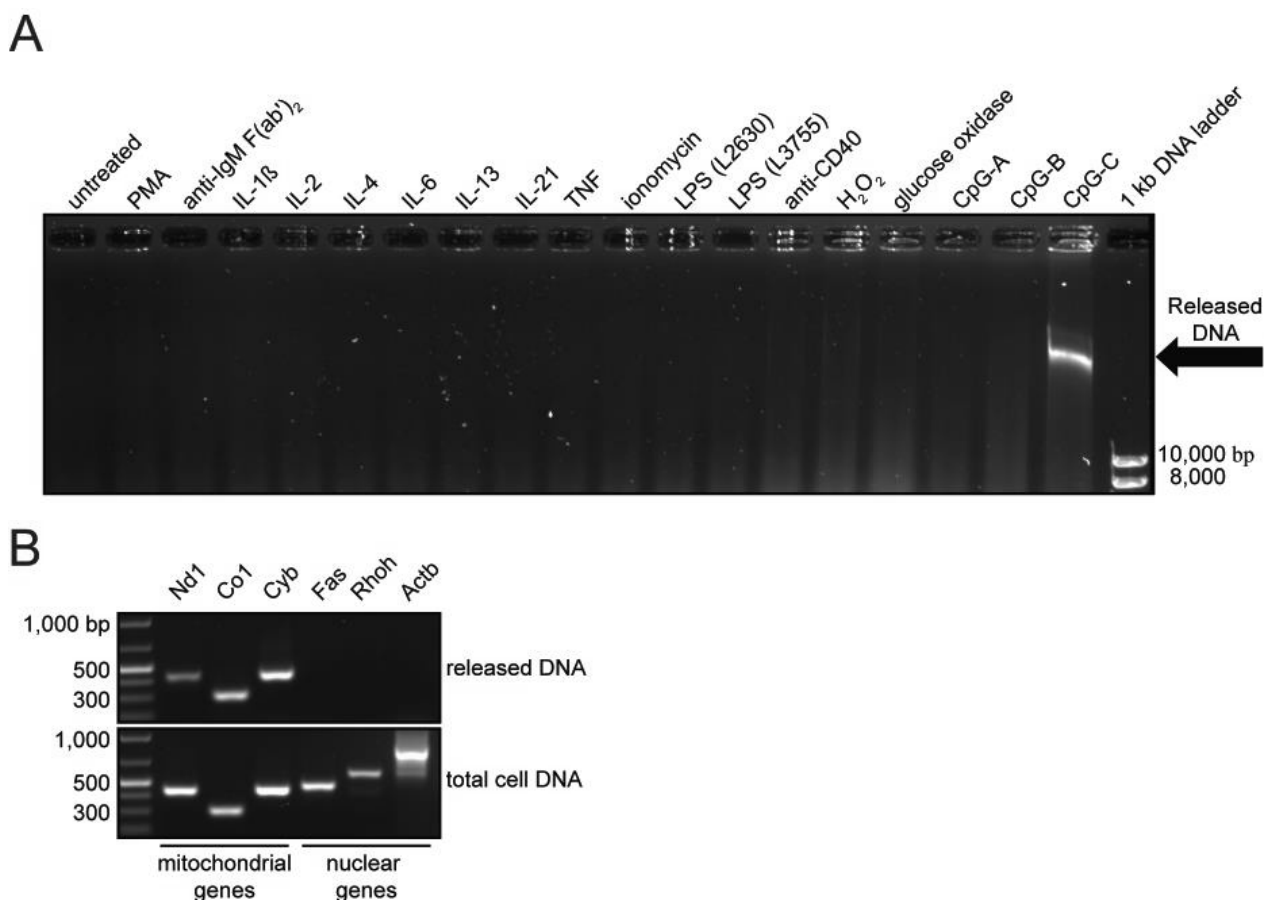

Figure 8. Evaluation of different molecules to induce DNA release in $B$ cells, and determination of the origin of CpG-C induced DNA. (A) Gel electrophoresis revealed that only $\mathrm{CpG}-\mathrm{C}$ induced DNA release in B cells. (B) By using primers for both mitochondrial and nuclear genes we could show that CpG-C induced DNA in $\mathrm{B}$ cells was of mitochondrial origin.

Although we did not investigate functional properties of these ETs more than on direct microbial cytotoxicity, oxidized mtDNA ETs released from neutrophils has been shown be proinflammatory, by inducing gene expression of TNF, IL-6 and typ I IFN in PBMCs (Lood et al. 2016). mtDNA is also a well-known DAMP that can alert the immune system in a proinflammatory fashion (Nakahira et al. 2015). Levels of mtDNA as well as NETs are elevated in various inflammatory conditions (Hajizadeh et al. 2003, Cossarizza et al. 2011, Wang et al. 2015), and of particular interest, for us, in AAV (Surmiak et al. 2015). 
This suggests physiological relevance of aberrant mtDNA levels. Future studies in AAV could investigate whether this is a consequence of increased production or altered clearance, as previous studies on NETs indicate. Although the origin of mtDNA in the circulation is not possible to confer per se, in vitro studies can be performed to evaluate spontaneous or induced mtDNA release when trying to locate potential sources for mtDNA release. With the new mechanism of mtDNA web release in lymphocytes, we suggest that such experiments now should also include $\mathrm{B}$ and $\mathrm{T}$ cells.

\section{mtDNA web release pathway does not induce ROS/RNS nor cell death}

ET release by cells of myeloid origin has been described for eosinophils, basophils, mast cells and neutrophils. This mechanism has been reported to differ in the involvement of ROS signalling as well as of cell death; suicidal vs. vital NETosis (Stoiber et al. 2015, Yang et al. 2016). Therefore, we wanted to evaluate both these aspects. We first observed that mtDNA web release did not depend on ROS/RNS production, when evaluating total ROS production as well as mitochondrial superoxide production. This was also confirmed as the ROS inhibitors diphenyleneiodonium (DPI) and apocynin as well as the ROS scavengers catalase and SOD had no effect on mtDNA release. We could also observe that the cells remained viable after web release. This was evaluated with measurements of released LDH (Fig. 9A) (which leaks out in the case of membrane rupture such as during certain forms of ETosis or necrosis), proliferation (Fig. 9B) and an assay simultaneously measuring apoptosis, necrosis and viability (fig. 9C).

A

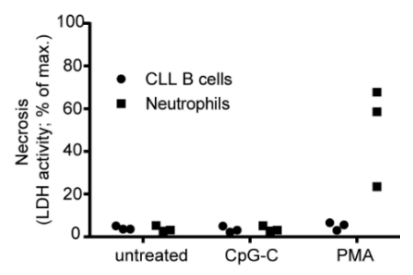

B

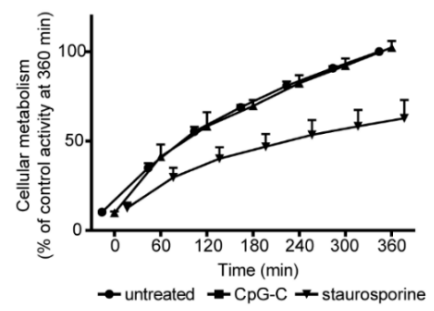

C

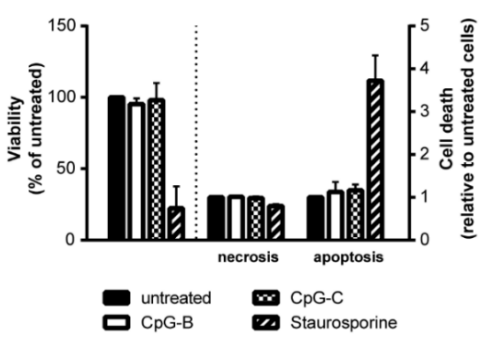

Figure 9. Viability check after CpG-C stimulation with three different assays. Viability was evaluated by measurement of (A) LDH (B) proliferation and (C) viability/ necrosis/ apoptosis (in the same assay). All three assays revealed that the $\mathrm{B}$ cells after $\mathrm{CpG}$-stimulation remained viable. 


\section{mtDNA web release operates in parallel with BCR, TLR9, STING and AIM2 signals}

In addition to the information that mtDNA release occurs independent of ROS/RNS signalling and cell death, we also analysed the involvement of BCR, TLR9, STING and AIM2. As previously described, TLR9 can be activated by CpG-C. B cells express TLR9 both in the endosome as well as on the cell surface (Guerrier et al. 2014). We could, however, not block mtDNA web release when using chloroquine (a known endosomal inhibitor), rolipram (inhibits PDE4, which blocks intracellular TLR-9 signalling) or wortmannin (inhibits PI3K and autophagy, and presents CpG co-localization with TLR9), indicating that web formation operates via another route than TLR9. To confirm that TLR9 signalling was successfully inhibited in our experiments, we also analysed TLR9 dependent IL-10 production in parallel with mtDNA after treatment with chloroquine, and chloroquine did as expected abolish IL-10 production indicating that TLR9 signalling indeed was inhibited. Further, when stimulating B cells with an anti-TLR9 antibody, we could not observe any differences in mtDNA release. To rule out the route of BCR signalling, we stimulated B cells with anti-IgM F(ab)2 but this did not induce mtDNA release. Also, when inhibiting the BCR signalling pathway $\mathrm{CpG}-\mathrm{C}$ still induced mtDNA release. As mtDNA also can be sensed by cytosolic receptors (Paludan and Bowie 2013), we blocked the AIM2-inflammasome, but again without any success in inhibiting mtDNA release. We also evaluated the DNA sensing pathway involving STING signalling. Stimulation of STING induces release of type I IFNs, and we observed type I IFN production from cells treated with CpG-C. Type I IFN production was, however, reduced after treatment with chloroquine, but this treatment did not affect the release of mtDNA. This indicates that the STING signalling pathway is not involved in CpG-C-induced mtDNA formation. In summary, mtDNA release does not rely on BCR, TLR9, AIM2 or STING signalling. Future studies will have to continue the search for this novel signalling pathway. 


\section{Paper IV}

Members in our group had previously observed altered levels of CD25+ B cells in patients with $\mathrm{AAV}$, and $\mathrm{CD} 25^{+} \mathrm{B}$ cells are often connected to immune regulation. Therefore, we now measured the frequencies of three different proposed Breg cell populations in AAV, including some that express CD25. We also expanded the phenotype analysis of these populations. We hypothesized that Breg cell levels would be reduced during active disease. In addition, we also wanted to measure the levels of B1 and MZ B cells in AAV patients as we hypothesize that a dysregulation of these cells could be important in AAV.

\section{Reduced levels of innate-like B cells in the circulation of patients}

We measured the frequencies of the innate-like B cell populations B1 and MZ B cells in the circulation, which have not previously been studied in AAV. MZ-like B cells were defined as $\mathrm{CD} 27^{+} \operatorname{IgD}{ }^{+} \operatorname{IgM}^{\text {high }}$ and B1-like B cells as $\mathrm{CD} 20^{+} \mathrm{CD} 27^{+} \mathrm{CD} 43^{+} \mathrm{CD} 70^{-}$. We found the proportions of MZ-like B cells within the B cell population as well as absolute numbers of these cells to be reduced in the circulation of patients both with active disease and in remission compared with HC (Fig. 10A-B). The proportions of B1-like B cells within the B cell population did not differ between the groups, although patients independent on disease activity had lower absolute numbers of these cells (Fig. 10C-D). We could confirm in a treatment-naïve group of 14 active patients that the reduced proportions of MZ-like B cells were not a treatment-artefact as these patients also showed reduced frequencies compared with HC. Rituximab treatment has been shown to affect both cell number and the proportions of $\mathrm{B}$ cells, with repopulation of $\mathrm{CD} 24^{\text {high }} \mathrm{CD} 38^{\text {high }} \mathrm{B}$ cells rather than memory $\left(\mathrm{CD} 27^{+}\right) \mathrm{B}$ cells after treatment (Todd et al. 2014, Aybar et al. 2015). Thus, when excluding patients in remission previously treated with rituximab in our analysis, MZ-like B cells no longer showed reduced proportions in remission compared with HC. This implies that these cells primarily are reduced in the circulation of patients with active disease. 

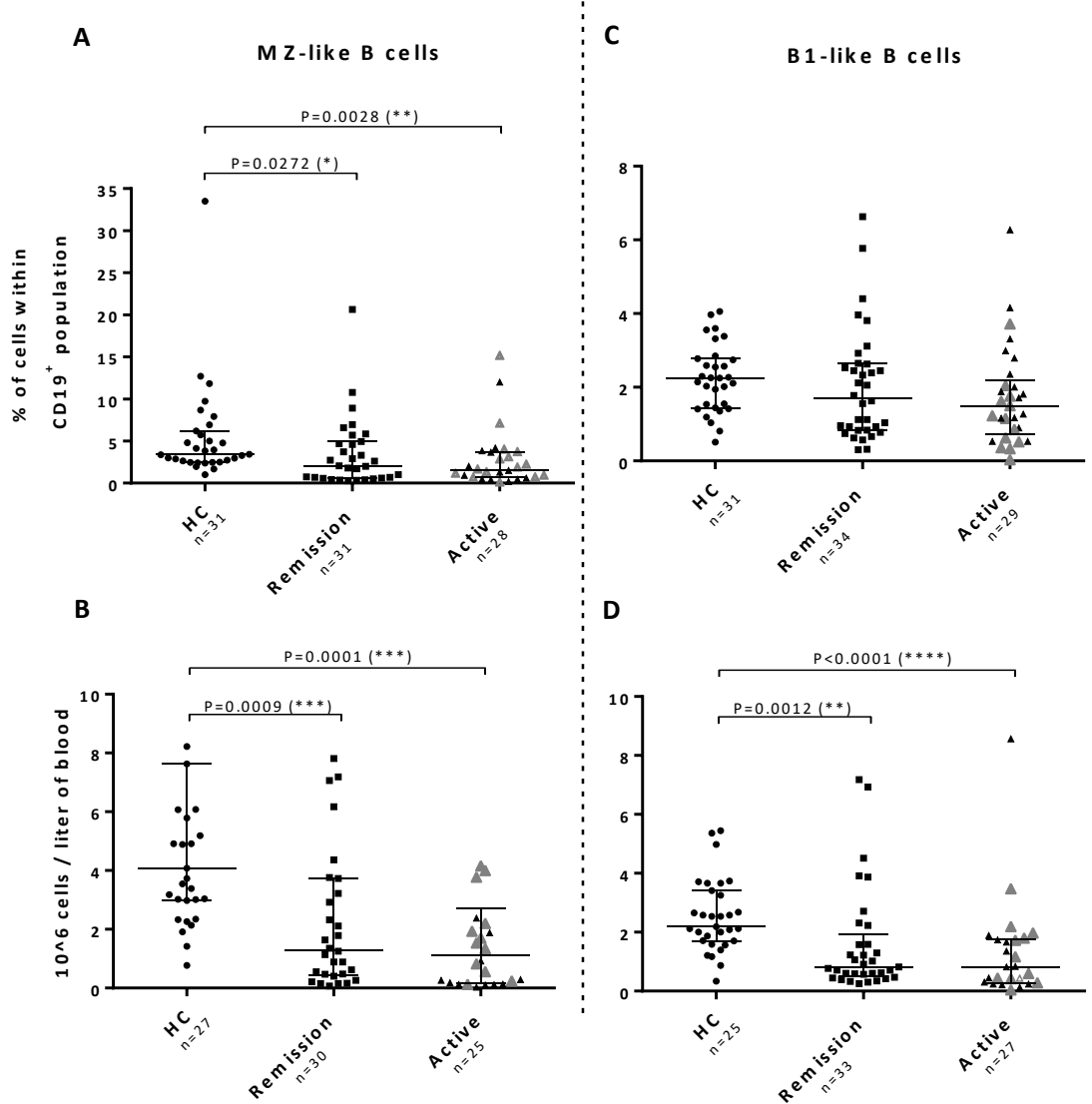

Figure 10. Frequencies of innate-like B cells in AAV. (A) Reduced percentages of MZ-like B cells within the B cell population were observed in patients independent of disease activity. (B, D) However, absolute numbers were lower for both MZ-like B cells and B1-like B cells in the patients. When excluding previously rituximab treated patients in the remission group, the percentage of MZ-like B cells did no longer differ from HC (data not shown), whereas untreated patients with active disease still had reduced levels of this population (data not shown). $* \mathrm{P}<0.05, * * \mathrm{P}<0.01, * * * \mathrm{P}<0.001, * * * * \mathrm{P}<0.0001$. 
Although no studies on MZ-like B cells have been performed in AAV, reduced proportions of $\mathrm{CD} 27^{+} \mathrm{IgD}^{+} \mathrm{IgM}^{+} \mathrm{B}$ cells have been reported in SLE. The study also showed that the levels of these cells in the circulation correlated negatively with the levels of autoantibodies (Rodriguez-Bayona et al. 2010). In addition, it was shown that $C D 27^{+} \operatorname{IgD}{ }^{+}$B cells (of which the majority also expressed $\operatorname{IgM}^{+}$) in SLE possessed an increased expression of for example CD80, CD86 and CXCR4 compared with HC. Due to the negative relation with antibody titers and the more activated phenotype in the patients, the authors suggested that they possibly are more prone to interact with $\mathrm{CD}^{+}{ }^{+} \mathrm{T}$ cells (Rodriguez-Bayona et al. 2010).

Studies on the relation between antibodies and MZ-like B cells as well as activation status on these cells would also be relevant to do in AAV as autoreactive B cells are thought to contribute to the pathogenesis. With our results in mind, one can ask whether the reduced levels of MZ-like B cells in the circulation reflect a lower total amount of MZ-like B cells, and if this in turn is related to lower amount of autoantibodies in the circulation. As some of the autoantibodies produced by MZ-like B cells are thought to contribute to homeostasis, reduced levels of this population could contribute to prolonged exposure of autoantigens eventually causing break of tolerance towards these antigens. Another question is whether reduced levels of MZ-like B cells in the circulation instead reflects that an increased amount of MZ-like B cells have migrated to other sites, such as germinal centers where interaction with $\mathrm{T}$ cells are possible. This could lead to production of high affinity autoantibodies from MZ-like B cells. It is also interesting that NETs from B cell helper neutrophils can boost MZ-like B cell antibody production in the marginal zone (Cerutti et al. 2013), especially when considering that patients in AAV release more NETs. 


\section{Reduced levels and altered phenotypes of Breg cells in the circulation of patients}

We observed reduced proportions and absolute numbers of the proposed Breg cell populations $\mathrm{CD} 24^{\text {high }} \mathrm{CD} 27^{+}$and $\mathrm{CD} 25^{+} \mathrm{CD} 27^{+} \mathrm{B}$ cells in patients, independent of disease activity, compared with HC (Fig. 11A-D). We also observed reduced absolute number of the $\mathrm{CD} 24^{\text {high }} \mathrm{CD} 38^{\text {high }}$ Breg cell population in both patient groups. These findings (as well as the reduced levels of MZ-like B cells) suggest a general defect in B cell regulation in AAV.
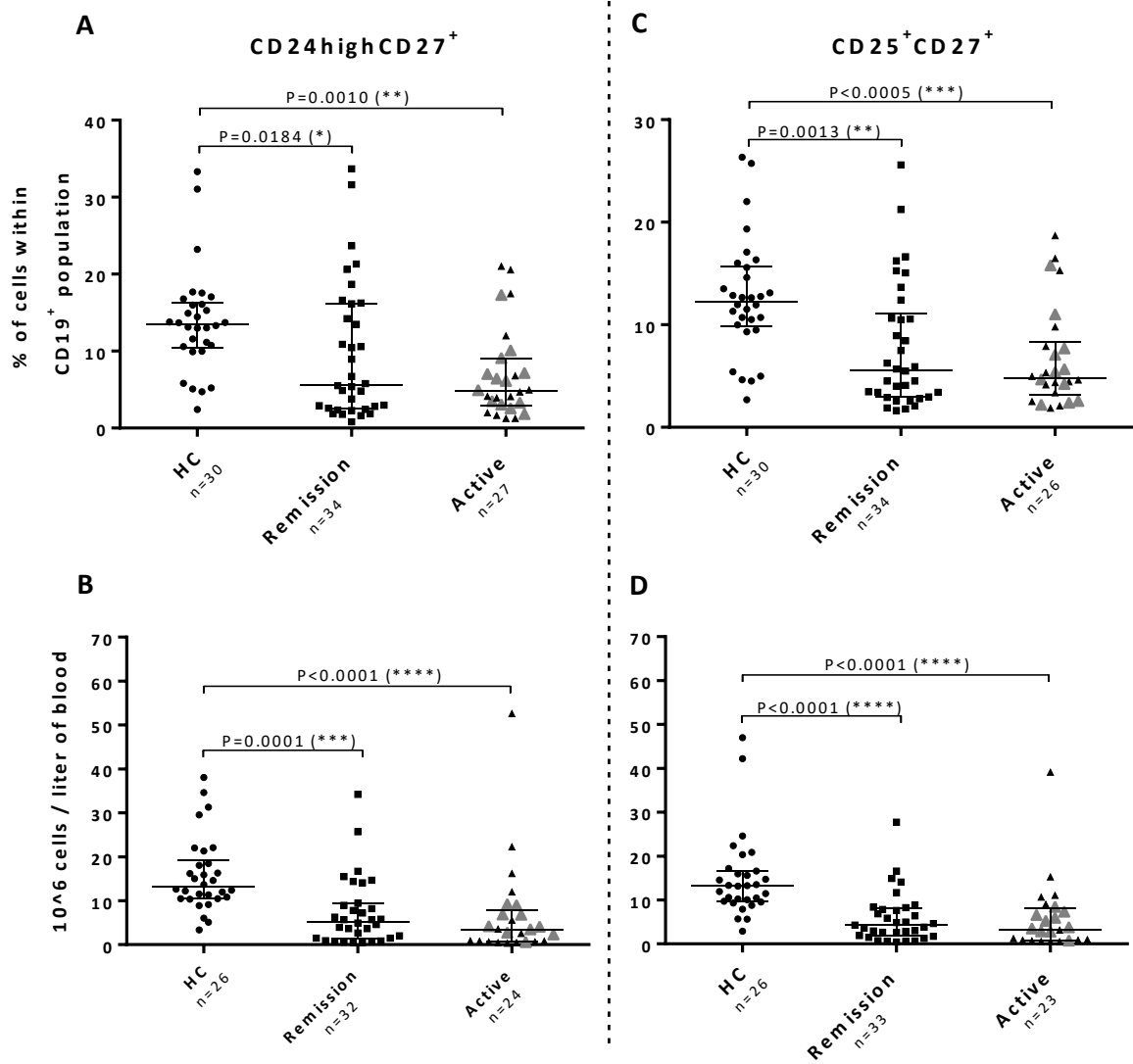

Figure 11. Frequencies of different Breg cell populations in AAV. (A, C) Percentages as well as (B, D) absolute numbers of $\mathrm{CD} 24^{\text {high }} \mathrm{CD} 27^{+}$and $\mathrm{CD} 25^{+} \mathrm{CD} 27^{+} \mathrm{B}$ cells were reduced in both patients with active disease and during remission. The results for patients with active disease were similar when excluding patients on treatment. However, when excluding patients in remission with previous rituximab treatment, the differences to $\mathrm{HC}$ for the percentages of Breg cells were abolished (data not shown). $* \mathrm{P}<0.05$, $* * \mathrm{P}<0.01, * * * \mathrm{P}<0.001$, $* * * * \mathrm{P}<0.0001$. 
$\mathrm{CD} 25^{+} \mathrm{CD} 27^{+} \mathrm{B}$ cells have previously not been reported on in $\mathrm{AAV}$, although similar result was observed in a previous study by members in our group presenting data on $\mathrm{CD} 25^{+} \mathrm{CD} 27^{-}$ B cells (Eriksson et al. 2010). Our findings of reduced proportions of $\mathrm{CD} 24^{\text {high }} \mathrm{CD} 27^{+} \mathrm{B}$ cells are also in line with some (Lepse et al. 2014, Land et al. 2015), but not all previous studies (Aybar et al. 2015). In the latter study the authors did not observe any differences between patients and HC. $\mathrm{CD} 24^{\text {high }} \mathrm{CD} 38^{\text {high }} \mathrm{B}$ cells have also been investigated by others but the results have been inconclusive (Lepse et al. 2014, Todd et al. 2014, Aybar et al. 2015, Land et al. 2015), indicating that this population needs further evaluation. As already described, rituximab treatment severely affects the B cell populations, with repopulation of $\mathrm{CD} 24^{\text {high }} \mathrm{CD} 38^{\text {high }} \mathrm{B}$ cells rather than memory $\left(\mathrm{CD} 27^{+}\right) \mathrm{B}$ cells, and is therefore an important factor that can influence the results. This is something that we also observed when we compared the percentages of $\mathrm{CD} 24^{\text {high }} \mathrm{CD} 38^{\text {high }} \mathrm{B}$ cells in patients who previously received rituximab treatment and those without treatment. As $\mathrm{CD} 24^{\text {high }} \mathrm{CD} 38^{\text {high }} \mathrm{B}$ cells are enriched with regulatory cells, this could be considered a positive treatment effect. When we excluded rituximab treated patients in remission from the analyses of $\mathrm{CD} 24^{\text {high }} \mathrm{CD} 27^{+}$and $\mathrm{CD} 25^{+} \mathrm{CD} 27^{+} \mathrm{B}$ cells, patients in remission did no longer differ from $\mathrm{HC}$. We also used treatment naïve active patients for these analyses, as for the innate-like cells described above, and observed also for $\mathrm{CD} 24^{\text {high }} \mathrm{CD} 27^{+}$and $\mathrm{CD} 25^{+} \mathrm{CD} 27^{+} \mathrm{B}$ cells that they were significantly reduced compared with $\mathrm{HC}$, similar to the whole group of active patients.

In addition to measurements of the frequencies of the proposed Breg cell populations, we also expanded the investigation of their phenotypes. In $\mathrm{HC}$ the $\mathrm{CD} 24^{\text {high }} \mathrm{CD} 27^{+}$population and the $\mathrm{CD} 25^{+} \mathrm{CD} 27^{+}$population overlapped with about $70 \%$. However, AAV patients independent of disease activity showed reduced percentages of CD25 expressing cells within the $\mathrm{CD} 24^{\text {high }} \mathrm{CD} 27^{+} \mathrm{B}$ cell population. Furthermore, CD86, PD-L1 and PD-L2 were increased on these cells during remission. CD25 in many different settings have been connected to immune regulation, and as we think that these patients possess an altered immune regulatory capacity this finding is interesting. However, we also think that remission is an active immunological state and therefore the differences between patients in remission and those with active disease are interesting, especially with respect to markers that have been connected to immune regulation; the positive co-stimulatory molecules CD86 (Blair et al. 2010) and negative co-stimulating molecules PD-L1/L2 (Latchman et al. 2001, Klinker and Lundy 2012). 


\section{Conclusion and future perspectives}

The release of ETs has caught attention in the last decade as an important tool of innate immunity to capture and kill microbes, but also to be involved in inflammatory diseases if dysregulated. Neutrophils are a driving force in the vessel inflammations observed in AAV, with release of inflammatory mediators such as ROS and NETs. NETs contain proinflammatory proteins and are thought to contribute to vessel inflammation directly by damaging endothelial cells and indirectly by acting as a link between the innate and adaptive immune system through the generation of pathogenic ANCA. However, ANCA can be found in all individuals and are therefore suggested to belong to the repertoire of natural antibodies produced by innate-like B cells. This imply that not all ANCA are pathogenic. In this thesis we have investigated mechanisms that we think contribute to the excessive inflammation in AAV, such as ROS and NETs, as well as measured the frequencies of innate-like B cells and Breg cells.

Our results show an increased spontaneous NETosis/necrosis and ANCA-induced ROS production in neutrophils from patients compared with neutrophils in $\mathrm{HC}$, as well as elevated levels of NETs in the circulation of patients. It also appears that the levels of NETs are higher during active disease than in remission. In addition to this, we observed a negative correlation between PR3-ANCA and NET remnants during remission, suggesting that ANCA can also aid in clearance of NETs. Formation of ETs has been designated a feature for cells of innate immunity, but in this thesis we describe that also lymphocytes ( $\mathrm{B}$ and $\mathrm{T}$ cells) of adaptive immunity can release similar structures, consisting of mtDNA. mtDNA is a well-known DAMP that can contribute to inflammation through activation of various cells, and increased levels of mtDNA have been observed in AAV. This encourage further studies on these cells in AAV. We also observed reduced frequencies of MZ-like B cells, considered to be innatelike $\mathrm{B}$ cells, and of the proposed Breg cell populations $\mathrm{CD} 24^{\text {high }} \mathrm{CD} 27^{+}$and $\mathrm{CD} 25^{+} \mathrm{CD} 27^{+} \mathrm{B}$ cells in patients, particularly in those with active disease. We also found the phenotypes of these Breg cell populations to be altered in patients compared with HC. 
In summary, we have observed neutrophils to be more easily activated in AAV patients and NETs to be elevated in the circulation, frequencies of both innate-like B cells and proposed Breg cell populations to be reduced, as well as altered phenotypes of the Breg cells. This altered immunological status could possibly favour the excessive vessel inflammation observed in AAV and the production of pathogenic ANCA. Fig.12 depicts a hypothetical model for development of AAV.

In future studies, we want to investigate interactions of neutrophils and B cells to evaluate the capacity of NETs to affect autoantibody production. As innate-like B cells can produce antibodies to TI antigens, a possibility is that NETs can regulate its own clearance by enhancing production of autoantibodies against NETs. It would thus be interesting to compare the amount of autoantibodies generated by these B cells in both patients and HC. Regarding innate-like B cells we also want to investigate additional surface markers to learn more about their activation status, as well as correlate the levels of these cells with the levels of ANCA in the circulation.

We are also interested to evaluate the cytotoxicity of NETs derived from neutrophils and other cells in both patients and HC. This would add another dimension to the role of NETs in AAV, in addition to only measure the levels. We also want to do similar studies on mtDNA, as well as measure mtDNA in the circulation of patients. Measurement of NETs in samples taken consecutively where relapsed are observed are also lacking. Thus, this should be performed for both NETs and mtDNA to be able to better estimate to what extent NETs and mtDNA can be used to monitor disease activity. As a continuation of this, different cell populations could be isolated and production of both NETs and mtDNA webs measured in the different populations. 
Although we have observed that there are both altered frequencies and phenotypes of proposed Breg cell populations, functional studies are crucial to perform before drawing any further conclusions about their role in AAV. There are many different approaches to perform this but I consider both cell-contact dependent mechanisms as well the effect of cytokines relevant to evaluate on cell proliferation and cytokine production of the responder's population. Responder cells could be either T cells or monocytes which are both relevant. Extern stimulation should be avoided as much as possible, and there are studies here activation of $\mathrm{T}$ cells can induce Breg cells, that in turn can limit $\mathrm{T}$ cell activation (Lemoine et al. 2011). I think that a similar approach would be suitable in our studies.

The purpose of the research presented in this thesis was to gain a better understanding of the immunological mechanisms contributing to the pathophysiology of AAV, and we hope that the obtained knowledge from these studies indeed can do that. We also hope that new projects can spurge based on our findings. The overall purpose of our research is to identify key mechanisms in the pathogenesis to which new drugs can be developed, as well as identify markers that can be used for diagnostic purposes to identify these diseases at an earlier stage. It would also be valuable to identify markers that can be used to better monitor disease activity, as this would allow treatments to be tailored and used more efficiently for each patients. 


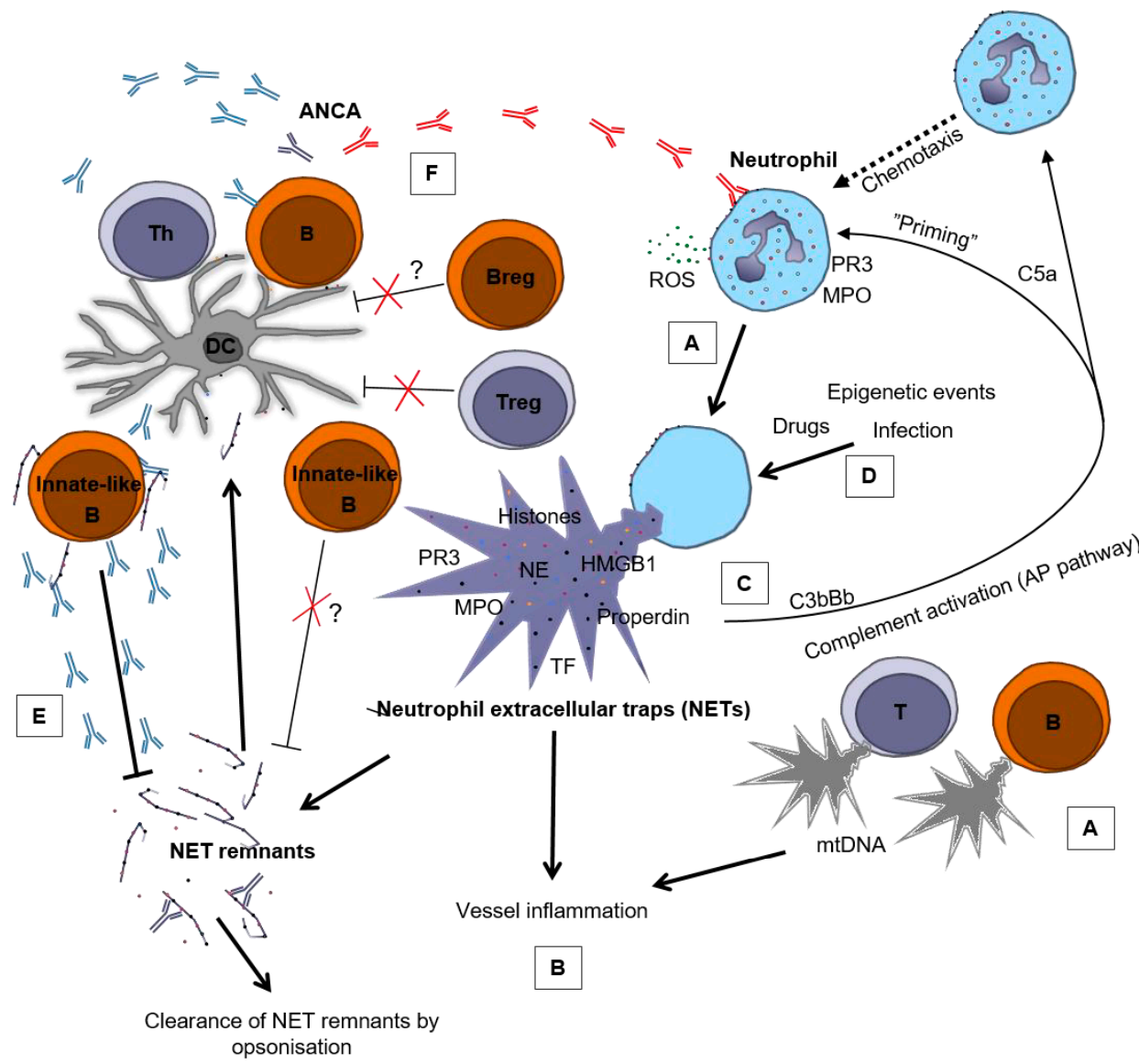

Figure 12. Hypothetical model for a vicious circle in AAV. (A) NETs are most probably formed at a constant rate in all individuals. ETs can also be released by a variety of other cells, and we show that this includes from $\mathrm{T}$ and B cells (or webs as we call these structures). (B) NETs contain proinflammatory mediators such as histones, HMGB1, PR3, NE and MPO (Urban et al. 2009, Papayannopoulos et al. 2010, Garcia-Romo et al. 2011) that contribute to vessel inflammation by damaging endothelial cells (Gupta et al. 2010, Villanueva et al. 2011, Saffarzadeh et al. 2012). Webs from $T$ and B cells consist of mtDNA, and mtDNA can promote inflammation by acting as a DAMP. (C) NETs promote recruitment of more neutrophils to the inflammatory site via activation of the alternative complement pathway (Wang et al. 2015). (D) Release of NETs can be highly enhanced by infections (Yipp et al. 2012), drugs (Nakazawa et al. 2012) and possibly epigenetic events (Ciavatta et al. 2010). (E) ANCA seem to belong to the repertoire of natural antibodies (Cui et al. 2010) and facilitate the clearance of NETs via opsonization (F) NETs can act as a link between innate and adaptive immunity through the generation of ANCA (Nakazawa et al. 2012, Sangaletti et al. 2012). Under unfavourable circumstances, such as upon a combination of increased antigen load due to increased NET formation and a dysregulation of innate-like and Treg and Breg cells, pathogenic ANCA are formed (red) that can activate neutrophils to release NETs (Kessenbrock et al. 2009, Nakazawa et al. 2014, Yoshida et al. 2016). This creates a vicious circle that promotes inflammation. 


\section{Acknowledgements}

Mårten Segelmark, main supervisor. Thank you so much for your encouragement and support during these years! I am very glad that I have gotten to know and work with you, as you have been an inspiration to me both within and outside science. I appreciate the responsibility you have given me in different projects, but I would also like to thank you for the opportunity to learn a lot of important things in addition to the laboratory work that are as necessary to be able to perform research. I'm also grateful for your understanding of my personal situation and that science in combination with shuttling between Lund/Malmö and Linköping actually works fine! (on the other hand, who would know that better than you)

Jan Ernerudh, co-supervisor. Thank you for introducing me to immunology at your lab seven years ago, I got hooked from the start! I have really appreciated your help throughout these years, and it means a lot to me that you signed up for the task as co-supervisor.

Per "Bregsson" Eriksson, co-supervisor. Your enthusiasm has been inspiring from the start and your expertise invaluable, especially on Bregs of course! Now I'm looking forward to more work on those Bregs.

Tino Kurz, co-supervisor. You impressed me from the beginning with your knowledge in cell biology when I first started in the group, and I have learnt so much from you! I am also glad for all the fun we have had at conferences at different places!.

Camilla Skoglund, thank you for bringing a lot of energy knowledge into our room during all these years and for the interesting and fun day-to-day discussions about, well, anything! (although mostly gating strategies lately....).

Björn Ingelsson, it has been so much fun and inspiring to work with you on our projects! When I first met you, you had never heard of NETs, and when I told you about them, you didn't believe they existed (as you told me afterwards). Now I know you do, and I am happy for you that you have found your own!

Anders Rosén, for good collaboration. It has been great to work in such exciting projects with you.

Marianne Petersson and Lotta Martinsson, thank you for great collaboration for many years in organizing sample collection!

Lund crew: Thomas Hellmark, Susanne Ohlsson, Lena Gunnarsson, Åsa Petersson, Sophie Ohlsson and Lisa Holm for collaboration on projects and fun times at conferences! I always have a good time when visiting your lab in Lund, thank you for that and introducing me to NET-ELISA of course! 
Atbin Motamedi, I think I can endorse you as an expert in ELISA now!

Birtt Sigfridsson, for good collaboration, you are an ace on the lab! Also thank you for fun discussions about both science and...golf!

Sandra Hellberg, for fun times but also your support in different situations we have stumbled on along the way from the first master's year.

Judit Svensson-Arvelund, for inspiring me to work with immunology and teaching me so much in the cell culture lab when I was a master's student. I learned a ton of things from you.

Simon Jönsson, for a lot of fun events throughout the years but thank you also for your tips and counselling in science related questions. Sinida could still become a success.

My friends and colleagues at LÄFO, but a special thank to:

Ida Bergström and Anna Lundberg, for showing me how to treat a cell-culture lab well! But also for helpful discussions about flow cytometry.

Emina Vorkapic, for fun times both at and outside work over the years!

Dick Wågsäter, for your enthusiasm!

Anik Islam, for help with flow cytometry related stuff and good times hanging out!

Ingrid Jakobsen, for fun parties and introducing me to cool new drinks! (did you ever try my "blandning"?)

Andreas Eriksson, for always being so nice and helpful and telling jokes during lunches.

Louise Karlsson, Niklas Björn and Svante Vikingsson for fun lunch and fika conversations!

Susanne Andersson, I really appreciate our chats in the lunch room, but I have not forgotten your help and encouragement especially when I was new as a student. It was very valuable.

Madeleine Örlin, a BIG thank you for all the help (often on short notice!) with all the paper work I didn't even know existed!

Eva och Magnus for both of you being sources of inspiration since I started at MedBi. And it's also cool of course that you appreciate the art of bandy!

Karin Persson, for always making me in good mood!

The students Henrik-Norlin Frisemo and Mathilda Strömberg that with great enthusiasm have helped me to better understand those B cells!

I would really like to thank the persons involved in the National Clinical Research School in Chronic Inflammatory diseases for two truly awesome years! I'm very thankful for all the things I've learned, which broaden my knowledge in this area, but I'm especially thankful for the friends that I made during this time.

Derby/Linköping bandy: för er förståelse när jag pga. celldödande kommer inspringandes till träning i sista minuten med "hälsingenötter" som middag. Snart ska jag vara först av alla till träningen, låångt före. 
Korten, Sörling och Spånga, för stunder som förgyllt livet i Linkan utanför labbet!

Mats, för att du lärt mig svinga en golfklubba (äntligen!), det har varit jäkligt kul och jag ser fram emot fortsättningen! Tack också för att du ställer upp i alla möjliga situationer och för stödet som trogen bandysupporter! Johanna och Herman för att ni är så energifyllda och att det alltid är så himla roligt att hänga med er, jag hoppas det kan bli mer nu när vi bara bor $100 \mathrm{~m}$ bort! Susanne och Ellen, för alla roliga stunder och för hur ni servat mig med de godaste bakverken jag ätit, målat i lägenheten och fixat med en massa praktiska saker genom åren när jag inte haft tid (eller inte vet hur man gör). Ni är verkliga mångsysslare. Ammi, jag är glad att jag fått lära känna dig och att vi nu kommer umgås ännu mer. Tur att du släppte in mig när jag blev utelåst från trapphuset igår kväll så jag kunde skriva klart detta.

Lars Landgren och Fredrik Luthman, för att ni spelar stor roll i vem jag är idag. Jag är otroligt tacksam att ha er som vänner.

Min härliga hälsingesläkt, för glädjen och tryggheten jag alltid fått från och känt från er. Vad jag har ältat om detta för er de senaste åren, men nu har jag fått ihop en bok till slut! Jag vill tacka mormor Birgit extra mycket som alltid undrar hur det går och "när jag ska bli klar i skolan”. Då kan jag säga att - Nu!

Mina föräldrar, Monica och Robin, för att ni genom hela livet stöttat mig vad jag än valt att göra. Det är en ovärderlig trygghet och något som jag alltid bär med mig. Cecilia, för att du är min fantastiska lilla-syrra! Det har betytt mycket att ha dig i närheten de här åren. Bara du hittar en ny plats så kommer jag och hälsar på! (även om just Madagaskar var i längsta laget...).

Julia Appelgren. Jag kan inte med ord beskriva hur otroligt lycklig du gör mig. Jag är så tacksam för det vi har och det stöd du är för mig. Jag fram emot alla nya äventyr som kommer! Du och jag. 


\section{References}

Abbas, A. K., A. H. Lichtman and S. Pillai (2012). Basic immunology : functions and disorders of the immune system. Philadelphia, Pa. ; London, Saunders.

Abdgawad, M., A. Pettersson, L. Gunnarsson, A. A. Bengtsson, P. Geborek, L. Nilsson, M. Segelmark and T. Hellmark (2012). "Decreased neutrophil apoptosis in quiescent ANCA-associated systemic vasculitis." PLoS One 7(3): e32439.

Abdulahad, W. H., N. Lepse, C. A. Stegeman, M. G. Huitema, B. Doornbos-van der Meer, H. Tadema, A. Rutgers, P. C. Limburg, C. G. Kallenberg and P. Heeringa (2013). "Increased frequency of circulating IL-21 producing Th-cells in patients with granulomatosis with polyangiitis (GPA)." Arthritis Res Ther 15(3): R70.

Abdulahad, W. H., C. A. Stegeman, Y. M. van der Geld, B. Doornbos-van der Meer, P. C. Limburg and C. G. Kallenberg (2007). "Functional defect of circulating regulatory CD4+ T cells in patients with Wegener's granulomatosis in remission." Arthritis Rheum 56(6): 2080-2091.

Abdulkader, R., S. E. Lane, D. G. Scott and R. A. Watts (2013). "Classification of vasculitis: EMA classification using CHCC 2012 definitions." Ann Rheum Dis 72(11): 1888.

Abreu-Velez, A. M., J. G. Smith, Jr. and M. S. Howard (2009). "Presence of neutrophil extracellular traps and antineutrophil cytoplasmic antibodies associated with vasculitides." N Am J Med Sci 1(6): 309-313.

Akira, S., S. Uematsu and O. Takeuchi (2006). "Pathogen recognition and innate immunity." Cell 124(4): 783801 .

Allenbach, Y., R. Seror, C. Pagnoux, L. Teixeira, P. Guilpain, L. Guillevin and G. French Vasculitis Study (2009). "High frequency of venous thromboembolic events in Churg-Strauss syndrome, Wegener's granulomatosis and microscopic polyangiitis but not polyarteritis nodosa: a systematic retrospective study on 1130 patients." Ann Rheum Dis 68(4): 564-567.

Allman, D. and S. Pillai (2008). "Peripheral B cell subsets." Curr Opin Immunol 20(2): 149-157.

Amu, S., A. Tarkowski, T. Dorner, M. Bokarewa and M. Brisslert (2007). "The human immunomodulatory CD25+ B cell population belongs to the memory B cell pool." Scand J Immunol 66(1): 77-86.

Amulic, B., C. Cazalet, G. L. Hayes, K. D. Metzler and A. Zychlinsky (2012). "Neutrophil function: from mechanisms to disease." Annu Rev Immunol 30: 459-489.

Aybar, L. T., J. G. McGregor, S. L. Hogan, Y. Hu, C. E. Mendoza, E. J. Brant, C. J. Poulton, C. D. Henderson, R. J. Falk and D. O. Bunch (2015). "Reduced CD5(+) CD24(hi) CD38(hi) and interleukin-10(+) regulatory B cells in active anti-neutrophil cytoplasmic autoantibody-associated vasculitis permit increased circulating autoantibodies." Clin Exp Immunol 180(2): 178-188.

Balavoine, A. S., D. Glinoer, S. Dubucquoi and J. L. Wemeau (2015). "Antineutrophil Cytoplasmic AntibodyPositive Small-Vessel Vasculitis Associated with Antithyroid Drug Therapy: How Significant Is the Clinical Problem?" Thyroid 25(12): 1273-1281.

Baslund, B., J. Petersen, H. Permin, A. Wiik and J. Wieslander (1994). "Measurements of proteinase 3 and its complexes with alpha 1-proteinase inhibitor and anti-neutrophil cytoplasm antibodies (ANCA) in plasma." J Immunol Methods 175(2): 215-225.

Baumgarth, N. (2011). "The double life of a B-1 cell: self-reactivity selects for protective effector functions." Nat Rev Immunol 11(1): 34-46.

Bemark, M. (2015). "Translating transitions - how to decipher peripheral human B cell development." J Biomed Res 29(4): 264-284. 
Beutner, E. H. (1961). "Immunofluorescent Staining: The Fluorescent Antibody Method." Bacteriol Rev 25(1): 49-76.

Blair, P. A., L. Y. Norena, F. Flores-Borja, D. J. Rawlings, D. A. Isenberg, M. R. Ehrenstein and C. Mauri (2010). "CD19(+)CD24(hi)CD38(hi) B cells exhibit regulatory capacity in healthy individuals but are functionally impaired in systemic Lupus Erythematosus patients." Immunity 32(1): 129-140.

Brinkmann, V., U. Reichard, C. Goosmann, B. Fauler, Y. Uhlemann, D. S. Weiss, Y. Weinrauch and A. Zychlinsky (2004). "Neutrophil extracellular traps kill bacteria." Science 303(5663): 1532-1535.

Brooks, C. J., W. J. King, D. J. Radford, D. Adu, M. McGrath and C. O. Savage (1996). "IL-1 beta production by human polymorphonuclear leucocytes stimulated by anti-neutrophil cytoplasmic autoantibodies: relevance to systemic vasculitis." Clin Exp Immunol 106(2): 273-279.

Brubaker, S. W., K. S. Bonham, I. Zanoni and J. C. Kagan (2015). "Innate immune pattern recognition: a cell biological perspective." Annu Rev Immunol 33: 257-290.

Bruchfeld, A., M. Wendt, J. Bratt, A. R. Qureshi, S. Chavan, K. J. Tracey, K. Palmblad and I. Gunnarsson (2011). "High-mobility group box-1 protein (HMGB1) is increased in antineutrophilic cytoplasmatic antibody (ANCA)associated vasculitis with renal manifestations." Mol Med 17(1-2): 29-35.

Bunch, D. O., J. G. McGregor, N. B. Khandoobhai, L. T. Aybar, M. E. Burkart, Y. Hu, S. L. Hogan, C. J. Poulton, E. A. Berg, R. J. Falk and P. H. Nachman (2013). "Decreased CD5(+) B cells in active ANCA vasculitis and relapse after rituximab." Clin J Am Soc Nephrol 8(3): 382-391.

Bunch, D. O., C. E. Mendoza, L. T. Aybar, E. S. Kotzen, K. R. Colby, Y. Hu, S. L. Hogan, C. J. Poulton, J. L. Schmitz, R. J. Falk, P. H. Nachman, W. F. Pendergraft and J. G. McGregor (2015). "Gleaning relapse risk from B cell phenotype: decreased CD5+ B cells portend a shorter time to relapse after B cell depletion in patients with ANCA-associated vasculitis." Ann Rheum Dis 74(9): 1784-1786.

Canton, J., D. Neculai and S. Grinstein (2013). "Scavenger receptors in homeostasis and immunity." Nat Rev Immunol 13(9): 621-634.

Caramalho, I., H. Nunes-Cabaco, R. B. Foxall and A. E. Sousa (2015). "Regulatory T-Cell Development in the Human Thymus." Front Immunol 6: 395.

Cerutti, A., M. Cols and I. Puga (2013). "Marginal zone B cells: virtues of innate-like antibody-producing lymphocytes." Nat Rev Immunol 13(2): 118-132.

Chen, M., G. Q. Xing, F. Yu, G. Liu and M. H. Zhao (2009). "Complement deposition in renal histopathology of patients with ANCA-associated pauci-immune glomerulonephritis." Nephrol Dial Transplant 24(4): 1247-1252.

Ciavatta, D. J., J. Yang, G. A. Preston, A. K. Badhwar, H. Xiao, P. Hewins, C. M. Nester, W. F. Pendergraft, 3rd, T. R. Magnuson, J. C. Jennette and R. J. Falk (2010). "Epigenetic basis for aberrant upregulation of autoantigen genes in humans with ANCA vasculitis." J Clin Invest 120(9): 3209-3219.

Cockwell, P., C. J. Brooks, D. Adu and C. O. Savage (1999). "Interleukin-8: A pathogenetic role in antineutrophil cytoplasmic autoantibody-associated glomerulonephritis." Kidney Int 55(3): 852-863.

Cossarizza, A., M. Pinti, M. Nasi, L. Gibellini, S. Manzini, E. Roat, S. De Biasi, L. Bertoncelli, J. P. Montagna, L. Bisi, L. Manzini, T. Trenti, V. Borghi and C. Mussini (2011). "Increased plasma levels of extracellular mitochondrial DNA during HIV infection: a new role for mitochondrial damage-associated molecular patterns during inflammation." Mitochondrion 11(5): 750-755.

Crotty, S. (2011). "Follicular helper CD4 T cells (TFH)." Annu Rev Immunol 29: 621-663.

Csernok, E., M. Ernst, W. Schmitt, D. F. Bainton and W. L. Gross (1994). "Activated neutrophils express proteinase 3 on their plasma membrane in vitro and in vivo." Clin Exp Immunol 95(2): 244-250. 
Cui, Z., M. H. Zhao, M. Segelmark and T. Hellmark (2010). "Natural autoantibodies to myeloperoxidase, proteinase 3, and the glomerular basement membrane are present in normal individuals." Kidney Int 78(6): 590597.

Dandona, P., M. Suri, W. Hamouda, A. Aljada, Y. Kumbkarni and K. Thusu (1999). "Hydrocortisone-induced inhibition of reactive oxygen species by polymorphonuclear neutrophils." Crit Care Med 27(11): 2442-2444.

Dwivedi, N., J. Upadhyay, I. Neeli, S. Khan, D. Pattanaik, L. Myers, K. A. Kirou, B. Hellmich, B. Knuckley, P. R. Thompson, M. K. Crow, T. R. Mikuls, E. Csernok and M. Radic (2012). "Felty's syndrome autoantibodies bind to deiminated histones and neutrophil extracellular chromatin traps." Arthritis Rheum 64(4): 982-992.

Ehrenstein, M. R. and C. A. Notley (2010). "The importance of natural IgM: scavenger, protector and regulator." Nat Rev Immunol 10(11): 778-786.

El Kebir, D., L. Jozsef, W. Pan and J. G. Filep (2008). "Myeloperoxidase delays neutrophil apoptosis through CD11b/CD18 integrins and prolongs inflammation." Circ Res 103(4): 352-359.

Eriksson, P. (2005). "Nine patients with anti-neutrophil cytoplasmic antibody-positive vasculitis successfully treated with rituximab." J Intern Med 257(6): 540-548.

Eriksson, P., C. Andersson, P. Cassel, S. Nystrom and J. Ernerudh (2015). "Increase in Th17-associated CCL20 and decrease in Th2-associated CCL22 plasma chemokines in active ANCA-associated vasculitis." Scand J Rheumatol 44(1): 80-83.

Eriksson, P., L. Jacobsson, A. Lindell, J. A. Nilsson and T. Skogh (2009). "Improved outcome in Wegener's granulomatosis and microscopic polyangiitis? A retrospective analysis of 95 cases in two cohorts." J Intern Med 265(4): 496-506.

Eriksson, P., C. Sandell, K. Backteman and J. Ernerudh (2010). "B cell abnormalities in Wegener's granulomatosis and microscopic polyangiitis: role of CD25+-expressing B cells." J Rheumatol 37(10): 2086-2095.

Ewert, B. H., J. C. Jennette and R. J. Falk (1992). "Anti-myeloperoxidase antibodies stimulate neutrophils to damage human endothelial cells." Kidney Int 41(2): 375-383.

Fadok, V. A., D. L. Bratton, A. Konowal, P. W. Freed, J. Y. Westcott and P. M. Henson (1998). "Macrophages that have ingested apoptotic cells in vitro inhibit proinflammatory cytokine production through autocrine/paracrine mechanisms involving TGF-beta, PGE2, and PAF." J Clin Invest 101(4): 890-898.

Falk, R. J., W. L. Gross, L. Guillevin, G. S. Hoffman, D. R. Jayne, J. C. Jennette, C. G. Kallenberg, R. Luqmani, A. D. Mahr, E. L. Matteson, P. A. Merkel, U. Specks and R. A. Watts (2011). "Granulomatosis with polyangiitis (Wegener's): an alternative name for Wegener's granulomatosis." Arthritis Rheum 63(4): 863-864.

Falk, R. J., R. S. Terrell, L. A. Charles and J. C. Jennette (1990). "Anti-neutrophil cytoplasmic autoantibodies induce neutrophils to degranulate and produce oxygen radicals in vitro." Proc Natl Acad Sci U S A 87(11): 41154119 .

Farrera, C. and B. Fadeel (2013). "Macrophage clearance of neutrophil extracellular traps is a silent process." J Immunol 191(5): 2647-2656

Flossmann, O. (2015). "Risks of treatments and long-term outcomes of systemic ANCA-associated vasculitis." Presse Med 44(6 Pt 2): e251-257.

Francisco, L. M., P. T. Sage and A. H. Sharpe (2010). "The PD-1 pathway in tolerance and autoimmunity." Immunol Rev 236: 219-242.

Fuchs, T. A., U. Abed, C. Goosmann, R. Hurwitz, I. Schulze, V. Wahn, Y. Weinrauch, V. Brinkmann and A. Zychlinsky (2007). "Novel cell death program leads to neutrophil extracellular traps." J Cell Biol 176(2): 231 241 . 
Fuchs, T. A., A. Brill, D. Duerschmied, D. Schatzberg, M. Monestier, D. D. Myers, Jr., S. K. Wrobleski, T. W. Wakefield, J. H. Hartwig and D. D. Wagner (2010). "Extracellular DNA traps promote thrombosis." Proc Natl Acad Sci U S A 107(36): 15880-15885.

Gabillet, J., A. Millet, M. Pederzoli-Ribeil, P. Tacnet-Delorme, L. Guillevin, L. Mouthon, P. Frachet and V. Witko-Sarsat (2012). "Proteinase 3, the autoantigen in granulomatosis with polyangiitis, associates with calreticulin on apoptotic neutrophils, impairs macrophage phagocytosis, and promotes inflammation." J Immunol 189(5): 2574-2583.

Gadola, S. D. and W. L. Gross (2012). "Vasculitis in 2011: The renaissance of granulomatous inflammation in AAV." Nat Rev Rheumatol.

Garcia-Romo, G. S., S. Caielli, B. Vega, J. Connolly, F. Allantaz, Z. Xu, M. Punaro, J. Baisch, C. Guiducci, R. L. Coffman, F. J. Barrat, J. Banchereau and V. Pascual (2011). "Netting neutrophils are major inducers of type I IFN production in pediatric systemic lupus erythematosus." Sci Transl Med 3(73): 73ra20.

Geijtenbeek, T. B. and S. I. Gringhuis (2009). "Signalling through C-type lectin receptors: shaping immune responses." Nat Rev Immunol 9(7): 465-479.

Goldmann, O. and E. Medina (2012). "The expanding world of extracellular traps: not only neutrophils but much more." Front Immunol 3: 420.

Gomes, A. M., F. Nery, A. Ventura, C. Almeida and J. Seabra (2009). "Familial clusters of ANCA small-vessel vasculitis." NDT Plus 2(1): 34-35.

Gomez-Puerta, J. A., L. Gedmintas and K. H. Costenbader (2013). "The association between silica exposure and development of ANCA-associated vasculitis: systematic review and meta-analysis." Autoimmun Rev 12(12): 1129-1135.

Gray, R. D., C. D. Lucas, A. Mackellar, F. Li, K. Hiersemenzel, C. Haslett, D. J. Davidson and A. G. Rossi (2013). "Activation of conventional protein kinase $\mathrm{C}(\mathrm{PKC})$ is critical in the generation of human neutrophil extracellular traps." J Inflamm (Lond) 10(1): 12.

Grayson, P. C., C. Carmona-Rivera, L. Xu, N. Lim, Z. Gao, A. L. Asare, U. Specks, J. H. Stone, P. Seo, R. F. Spiera, C. A. Langford, G. S. Hoffman, C. G. Kallenberg, E. W. St Clair, N. K. Tchao, S. R. Ytterberg, D. J. Phippard, P. A. Merkel, M. J. Kaplan and P. A. Monach (2015). "Neutrophil-Related Gene Expression and LowDensity Granulocytes Associated With Disease Activity and Response to Treatment in Antineutrophil Cytoplasmic Antibody-Associated Vasculitis." Arthritis Rheumatol 67(7): 1922-1932.

Griffin, D. O., N. E. Holodick and T. L. Rothstein (2011). "Human B1 cells are CD3-: A reply to "A human equivalent of mouse B-1 cells?" and "The nature of circulating CD27+CD43+ B cells"." J Exp Med 208(13): 2566-2569.

Griffin, D. O. and T. L. Rothstein (2012). "Human "orchestrator" CD11b(+) B1 cells spontaneously secrete interleukin-10 and regulate T-cell activity." Mol Med 18: 1003-1008.

Griffin, S. V., P. T. Chapman, E. A. Lianos and C. M. Lockwood (1999). "The inhibition of myeloperoxidase by ceruloplasmin can be reversed by anti-myeloperoxidase antibodies." Kidney Int 55(3): 917-925.

Guerrier, T., P. Pochard, A. Lahiri, P. Youinou, J. O. Pers and C. Jamin (2014). "TLR9 expressed on plasma membrane acts as a negative regulator of human B cell response." J Autoimmun 51: 23-29.

Guimaraes-Costa, A. B., M. T. Nascimento, G. S. Froment, R. P. Soares, F. N. Morgado, F. Conceicao-Silva and E. M. Saraiva (2009). "Leishmania amazonensis promastigotes induce and are killed by neutrophil extracellular traps." Proc Natl Acad Sci U S A 106(16): 6748-6753.

Guo, H., J. B. Callaway and J. P. Ting (2015). "Inflammasomes: mechanism of action, role in disease, and therapeutics." Nat Med 21(7): 677-687. 
Gupta, A. K., P. Hasler, W. Holzgreve, S. Gebhardt and S. Hahn (2005). "Induction of neutrophil extracellular DNA lattices by placental microparticles and IL-8 and their presence in preeclampsia." Hum Immunol 66(11): 1146-1154.

Gupta, A. K., M. B. Joshi, M. Philippova, P. Erne, P. Hasler, S. Hahn and T. J. Resink (2010). "Activated endothelial cells induce neutrophil extracellular traps and are susceptible to NETosis-mediated cell death." FEBS Lett 584(14): 3193-3197.

Hajizadeh, S., J. DeGroot, J. M. TeKoppele, A. Tarkowski and L. V. Collins (2003). "Extracellular mitochondrial DNA and oxidatively damaged DNA in synovial fluid of patients with rheumatoid arthritis." Arthritis Res Ther 5(5): R234-240.

Hakkim, A., B. G. Furnrohr, K. Amann, B. Laube, U. A. Abed, V. Brinkmann, M. Herrmann, R. E. Voll and A. Zychlinsky (2010). "Impairment of neutrophil extracellular trap degradation is associated with lupus nephritis." Proc Natl Acad Sci U S A 107(21): 9813-9818.

Halbwachs-Mecarelli, L., G. Bessou, P. Lesavre, S. Lopez and V. Witko-Sarsat (1995). "Bimodal distribution of proteinase 3 (PR3) surface expression reflects a constitutive heterogeneity in the polymorphonuclear neutrophil pool." FEBS Lett 374(1): 29-33.

Haubitz, M., P. Schulzeck, S. Schellong, M. Schulze, K. M. Koch and R. Brunkhorst (1997). "Complexed plasma elastase as an in vivo marker for leukocyte activation in antineutrophil cytoplasmic antibody-associated vasculitis." Arthritis Rheum 40(9): 1680-1684.

Hay, E. M., M. Beaman, A. J. Ralston, P. Ackrill, R. M. Bernstein and P. J. Holt (1991). "Wegener's granulomatosis occurring in siblings." Br J Rheumatol 30(2): 144-145.

Henshaw, T. J., C. C. Malone, J. E. Gabay and R. C. Williams, Jr. (1994). "Elevations of neutrophil proteinase 3 in serum of patients with Wegener's granulomatosis and polyarteritis nodosa." Arthritis Rheum 37(1): 104-112.

Hilhorst, M., B. Wilde, P. van Paassen, B. Winkens, P. van Breda Vriesman, J. W. Cohen Tervaert and R. Limburg Renal (2013). "Improved outcome in anti-neutrophil cytoplasmic antibody (ANCA)-associated glomerulonephritis: a 30-year follow-up study." Nephrol Dial Transplant 28(2): 373-379.

Hoffman, G. S. (2012). Inflammatory diseases of blood vessels. Oxford, Wiley-Blackwell.

Hofman, Z., S. de Maat, C. E. Hack and C. Maas (2016). "Bradykinin: Inflammatory Product of the Coagulation System." Clin Rev Allergy Immunol 51(2): 152-161.

Hruskova, Z., Z. Rihova, H. Mareckova, E. Jancova, R. Rysava, J. Zavada, M. Merta, T. Loster and V. Tesar (2009). "Intracellular cytokine production in ANCA-associated vasculitis: low levels of interleukin-10 in remission are associated with a higher relapse rate in the long-term follow-up." Arch Med Res 40(4): 276-284.

Huang, Y. M., H. Wang, C. Wang, M. Chen and M. H. Zhao (2015). "Promotion of hypercoagulability in antineutrophil cytoplasmic antibody-associated vasculitis by $\mathrm{C} 5 \mathrm{a}$-induced tissue factor-expressing microparticles and neutrophil extracellular traps." Arthritis Rheumatol 67(10): 2780-2790.

Huugen, D., H. Xiao, A. van Esch, R. J. Falk, C. J. Peutz-Kootstra, W. A. Buurman, J. W. Tervaert, J. C. Jennette and P. Heeringa (2005). "Aggravation of anti-myeloperoxidase antibody-induced glomerulonephritis by bacterial lipopolysaccharide: role of tumor necrosis factor-alpha." Am J Pathol 167(1): 47-58.

Imamoto, T., D. Nakazawa, H. Shida, A. Suzuki, N. Otsuka, U. Tomaru and A. Ishizu (2014). "Possible linkage between microscopic polyangiitis and thrombosis via neutrophil extracellular traps." Clin Exp Rheumatol 32(1): 149-150.

Itagaki, K., E. Kaczmarek, Y. T. Lee, I. T. Tang, B. Isal, Y. Adibnia, N. Sandler, M. J. Grimm, B. H. Segal, L. E. Otterbein and C. J. Hauser (2015). "Mitochondrial DNA released by trauma induces neutrophil extracellular traps." PLoS One 10(3): e0120549. 
Iwata, Y., T. Matsushita, M. Horikawa, D. J. Dilillo, K. Yanaba, G. M. Venturi, P. M. Szabolcs, S. H. Bernstein, C. M. Magro, A. D. Williams, R. P. Hall, E. W. St Clair and T. F. Tedder (2011). "Characterization of a rare IL10-competent B-cell subset in humans that parallels mouse regulatory B10 cells." Blood 117(2): 530-541.

Jaillon, S., G. Peri, Y. Delneste, I. Fremaux, A. Doni, F. Moalli, C. Garlanda, L. Romani, H. Gascan, S. Bellocchio, S. Bozza, M. A. Cassatella, P. Jeannin and A. Mantovani (2007). "The humoral pattern recognition receptor PTX3 is stored in neutrophil granules and localizes in extracellular traps." J Exp Med 204(4): 793-804.

Jennette, J. C. and R. J. Falk (1997). "Small-vessel vasculitis." N Engl J Med 337(21): 1512-1523.

Jennette, J. C. and R. J. Falk (2014). "Pathogenesis of antineutrophil cytoplasmic autoantibody-mediated disease." Nat Rev Rheumatol 10(8): 463-473.

Jennette, J. C., R. J. Falk, P. A. Bacon, N. Basu, M. C. Cid, F. Ferrario, L. F. Flores-Suarez, W. L. Gross, L. Guillevin, E. C. Hagen, G. S. Hoffman, D. R. Jayne, C. G. Kallenberg, P. Lamprecht, C. A. Langford, R. A. Luqmani, A. D. Mahr, E. L. Matteson, P. A. Merkel, S. Ozen, C. D. Pusey, N. Rasmussen, A. J. Rees, D. G. Scott, U. Specks, J. H. Stone, K. Takahashi and R. A. Watts (2013). "2012 revised International Chapel Hill Consensus Conference Nomenclature of Vasculitides." Arthritis Rheum 65(1): 1-11.

Jounai, N., K. Kobiyama, F. Takeshita and K. J. Ishii (2012). "Recognition of damage-associated molecular patterns related to nucleic acids during inflammation and vaccination." Front Cell Infect Microbiol 2: 168.

Jovanovic, D. V., J. A. Di Battista, J. Martel-Pelletier, F. C. Jolicoeur, Y. He, M. Zhang, F. Mineau and J. P. Pelletier (1998). "IL-17 stimulates the production and expression of proinflammatory cytokines, IL-beta and TNFalpha, by human macrophages." J Immunol 160(7): 3513-3521.

Kahn, R., T. Hellmark, L. M. Leeb-Lundberg, N. Akbari, M. Todiras, T. Olofsson, J. Wieslander, A. Christensson, K. Westman, M. Bader, W. Muller-Esterl and D. Karpman (2009). "Neutrophil-derived proteinase 3 induces kallikrein-independent release of a novel vasoactive kinin." J Immunol 182(12): 7906-7915.

Kain, R., M. Exner, R. Brandes, R. Ziebermayr, D. Cunningham, C. A. Alderson, A. Davidovits, I. Raab, R. Jahn, O. Ashour, S. Spitzauer, G. Sunder-Plassmann, M. Fukuda, P. Klemm, A. J. Rees and D. Kerjaschki (2008). "Molecular mimicry in pauci-immune focal necrotizing glomerulonephritis." Nat Med 14(10): 1088-1096.

Kallenberg, C. G. and P. Heeringa (2015). "Complement system activation in ANCA vasculitis: A translational success story?" Mol Immunol 68(1): 53-56.

Kambas, K., A. Chrysanthopoulou, D. Vassilopoulos, E. Apostolidou, P. Skendros, A. Girod, S. Arelaki, M. Froudarakis, L. Nakopoulou, A. Giatromanolaki, P. Sidiropoulos, M. Koffa, D. T. Boumpas, K. Ritis and I. Mitroulis (2014). "Tissue factor expression in neutrophil extracellular traps and neutrophil derived microparticles in antineutrophil cytoplasmic antibody associated vasculitis may promote thromboinflammation and the thrombophilic state associated with the disease." Ann Rheum Dis 73(10): 1854-1863.

Kantari, C., M. Pederzoli-Ribeil, O. Amir-Moazami, V. Gausson-Dorey, I. C. Moura, M. C. Lecomte, M. Benhamou and V. Witko-Sarsat (2007). "Proteinase 3, the Wegener autoantigen, is externalized during neutrophil apoptosis: evidence for a functional association with phospholipid scramblase 1 and interference with macrophage phagocytosis." Blood 110(12): 4086-4095.

Kaplan, M. J. and M. Radic (2012). "Neutrophil extracellular traps: double-edged swords of innate immunity." J Immunol 189(6): 2689-2695.

Kawai, T. and S. Akira (2009). "The roles of TLRs, RLRs and NLRs in pathogen recognition." Int Immunol 21(4): 317-337.

Kemna, M. J., J. Damoiseaux, J. Austen, B. Winkens, J. Peters, P. van Paassen and J. W. Cohen Tervaert (2015). "ANCA as a predictor of relapse: useful in patients with renal involvement but not in patients with nonrenal disease." J Am Soc Nephrol 26(3): 537-542. 
Keshari, R. S., A. Jyoti, M. Dubey, N. Kothari, M. Kohli, J. Bogra, M. K. Barthwal and M. Dikshit (2012). "Cytokines induced neutrophil extracellular traps formation: implication for the inflammatory disease condition." PLoS One 7(10): e48111.

Kessel, A., T. Haj, R. Peri, A. Snir, D. Melamed, E. Sabo and E. Toubi (2011). "Human CD19(+)CD25(high) B regulatory cells suppress proliferation of CD4(+) T cells and enhance Foxp3 and CTLA-4 expression in Tregulatory cells." Autoimmun Rev.

Kessenbrock, K., M. Krumbholz, U. Schonermarck, W. Back, W. L. Gross, Z. Werb, H. J. Grone, V. Brinkmann and D. E. Jenne (2009). "Netting neutrophils in autoimmune small-vessel vasculitis." Nat Med 15(6): 623-625.

Kettritz, R. (2012). "How anti-neutrophil cytoplasmic autoantibodies activate neutrophils." Clin Exp Immunol 169(3): 220-228.

Khandpur, R., C. Carmona-Rivera, A. Vivekanandan-Giri, A. Gizinski, S. Yalavarthi, J. S. Knight, S. Friday, S. Li, R. M. Patel, V. Subramanian, P. Thompson, P. Chen, D. A. Fox, S. Pennathur and M. J. Kaplan (2013). "NETs are a source of citrullinated autoantigens and stimulate inflammatory responses in rheumatoid arthritis." Sci Transl Med 5(178): 178ra140.

Klein, J., J. Gonzalez, S. Decramer, F. Bandin, E. Neau, D. J. Salant, P. Heeringa, J. B. Pesquero, J. P. Schanstra and J. L. Bascands (2010). "Blockade of the kinin B1 receptor ameloriates glomerulonephritis." J Am Soc Nephrol 21(7): 1157-1164.

Klinker, M. W. and S. K. Lundy (2012). "Multiple mechanisms of immune suppression by B lymphocytes." Mol Med 18(1): 123-137

Klinker, M. W. and S. K. Lundy (2012). "Multiple mechanisms of immune suppression by B lymphocytes." Mol Med 18: 123-137.

Knight, A., S. Sandin and J. Askling (2008). "Risks and relative risks of Wegener's granulomatosis among close relatives of patients with the disease." Arthritis Rheum 58(1): 302-307.

Kono, H. and K. L. Rock (2008). "How dying cells alert the immune system to danger." Nat Rev Immunol 8(4): 279-289.

Korkmaz, B., M. S. Horwitz, D. E. Jenne and F. Gauthier (2010). "Neutrophil elastase, proteinase 3, and cathepsin $\mathrm{G}$ as therapeutic targets in human diseases." Pharmacol Rev 62(4): 726-759.

Kraaij, T., F. C. Tengstrom, S. W. Kamerling, C. D. Pusey, H. U. Scherer, R. E. Toes, T. J. Rabelink, C. van Kooten and Y. K. Teng (2016). "A novel method for high-throughput detection and quantification of neutrophil extracellular traps reveals ROS-independent NET release with immune complexes." Autoimmun Rev.

Kuhl, A., B. Korkmaz, B. Utecht, A. Kniepert, U. Schonermarck, U. Specks and D. E. Jenne (2010). "Mapping of conformational epitopes on human proteinase 3, the autoantigen of Wegener's granulomatosis." J Immunol 185(1): 387-399.

Kumar, S. V., O. P. Kulkarni, S. R. Mulay, M. N. Darisipudi, S. Romoli, D. Thomasova, C. R. Scherbaum, B. Hohenstein, C. Hugo, S. Muller, H. Liapis and H. J. Anders (2015). "Neutrophil Extracellular Trap-Related Extracellular Histones Cause Vascular Necrosis in Severe GN." J Am Soc Nephrol 26(10): 2399-2413.

Land, J., W. H. Abdulahad, J. S. Sanders, C. A. Stegeman, P. Heeringa and A. Rutgers (2015). "Regulatory and effector B cell cytokine production in patients with relapsing granulomatosis with polyangiitis." Arthritis Res Ther 18: 84 .

Land, J., W. H. Abdulahad, J. S. Sanders, C. A. Stegeman, P. Heeringa and A. Rutgers (2016). "Regulatory and effector B cell cytokine production in patients with relapsing granulomatosis with polyangiitis." Arthritis Res Ther 18: 84 .

Latchman, Y., C. R. Wood, T. Chernova, D. Chaudhary, M. Borde, I. Chernova, Y. Iwai, A. J. Long, J. A. Brown, R. Nunes, E. A. Greenfield, K. Bourque, V. A. Boussiotis, L. L. Carter, B. M. Carreno, N. Malenkovich, H. 
Nishimura, T. Okazaki, T. Honjo, A. H. Sharpe and G. J. Freeman (2001). "PD-L2 is a second ligand for PD-1 and inhibits T cell activation." Nat Immunol 2(3): 261-268.

Leffler, J., B. Gullstrand, A. Jonsen, J. A. Nilsson, M. Martin, A. M. Blom and A. A. Bengtsson (2013). "Degradation of neutrophil extracellular traps co-varies with disease activity in patients with systemic lupus erythematosus." Arthritis Res Ther 15(4): R84.

Leffler, J., M. Martin, B. Gullstrand, H. Tyden, C. Lood, L. Truedsson, A. A. Bengtsson and A. M. Blom (2012). "Neutrophil extracellular traps that are not degraded in systemic lupus erythematosus activate complement exacerbating the disease." J Immunol 188(7): 3522-3531.

Lefkowitz, D. L., M. P. Gelderman, S. R. Fuhrmann, S. Graham, J. D. Starnes, 3rd, S. S. Lefkowitz, A. Bollen and N. Moguilevsky (1999). "Neutrophilic myeloperoxidase-macrophage interactions perpetuate chronic inflammation associated with experimental arthritis." Clin Immunol 91(2): 145-155.

Lemoine, S., A. Morva, P. Youinou and C. Jamin (2011). "Human T cells induce their own regulation through activation of B cells." J Autoimmun 36(3-4): 228-238.

Lepse, N., W. H. Abdulahad, A. Rutgers, C. G. Kallenberg, C. A. Stegeman and P. Heeringa (2014). "Altered B cell balance, but unaffected B cell capacity to limit monocyte activation in anti-neutrophil cytoplasmic antibodyassociated vasculitis in remission." Rheumatology (Oxford) 53(9): 1683-1692.

Lood, C., L. P. Blanco, M. M. Purmalek, C. Carmona-Rivera, S. S. De Ravin, C. K. Smith, H. L. Malech, J. A. Ledbetter, K. B. Elkon and M. J. Kaplan (2016). "Neutrophil extracellular traps enriched in oxidized mitochondrial DNA are interferogenic and contribute to lupus-like disease." Nat Med 22(2): 146-153.

Lundqvist, H. and C. Dahlgren (1996). "Isoluminol-enhanced chemiluminescence: a sensitive method to study the release of superoxide anion from human neutrophils." Free Radic Biol Med 20(6): 785-792.

Luqmani, R. A. (2015). "Disease assessment in systemic vasculitis." Nephrol Dial Transplant 30 Suppl 1: i76-82.

Lyons, P. A., T. F. Rayner, S. Trivedi, J. U. Holle, R. A. Watts, D. R. Jayne, B. Baslund, P. Brenchley, A. Bruchfeld, A. N. Chaudhry, J. W. Cohen Tervaert, P. Deloukas, C. Feighery, W. L. Gross, L. Guillevin, I. Gunnarsson, L. Harper, Z. Hruskova, M. A. Little, D. Martorana, T. Neumann, S. Ohlsson, S. Padmanabhan, C. D. Pusey, A. D. Salama, J. S. Sanders, C. O. Savage, M. Segelmark, C. A. Stegeman, V. Tesar, A. Vaglio, S. Wieczorek, B. Wilde, J. Zwerina, A. J. Rees, D. G. Clayton and K. G. Smith (2012). "Genetically distinct subsets within ANCA-associated vasculitis." N Engl J Med 367(3): 214-223.

Ma, Y. H., T. T. Ma, C. Wang, H. Wang, D. Y. Chang, M. Chen and M. H. Zhao (2016). "High-mobility group box 1 potentiates antineutrophil cytoplasmic antibody-inducing neutrophil extracellular traps formation." Arthritis Res Ther 18: 2.

Manganelli, P., R. Giacosa, P. Fietta, A. Zanetti and T. M. Neri (2003). "Familial vasculitides: Churg-Strauss syndrome and Wegener's granulomatosis in 2 first-degree relatives." J Rheumatol 30(3): 618-621.

Mantovani, A., M. A. Cassatella, C. Costantini and S. Jaillon (2011). "Neutrophils in the activation and regulation of innate and adaptive immunity." Nat Rev Immunol 11(8): 519-531.

Maugeri, N., L. Campana, M. Gavina, C. Covino, M. De Metrio, C. Panciroli, L. Maiuri, A. Maseri, A. D'Angelo, M. E. Bianchi, P. Rovere-Querini and A. A. Manfredi (2014). "Activated platelets present high mobility group box 1 to neutrophils, inducing autophagy and promoting the extrusion of neutrophil extracellular traps." J Thromb Haemost 12(12): 2074-2088.

Mauri, C. and M. Menon (2015). "The expanding family of regulatory B cells." Int Immunol 27(10): 479-486.

Md Yusof, M. Y., E. M. Vital, S. Das, S. Dass, G. Arumugakani, S. Savic, A. C. Rawstron and P. Emery (2015). "Repeat cycles of rituximab on clinical relapse in ANCA-associated vasculitis: identifying B cell biomarkers for relapse to guide retreatment decisions." Ann Rheum Dis 74(9): 1734-1738. 
Menegazzi, R., E. Decleva and P. Dri (2012). "Killing by neutrophil extracellular traps: fact or folklore?" Blood 119(5): 1214-1216.

Merle, N. S., S. E. Church, V. Fremeaux-Bacchi and L. T. Roumenina (2015a). "Complement System Part I Molecular Mechanisms of Activation and Regulation." Front Immunol 6: 262.

Merle, N. S., R. Noe, L. Halbwachs-Mecarelli, V. Fremeaux-Bacchi and L. T. Roumenina (2015b). "Complement System Part II: Role in Immunity." Front Immunol 6: 257.

Millet, A., K. R. Martin, F. Bonnefoy, P. Saas, J. Mocek, M. Alkan, B. Terrier, A. Kerstein, N. Tamassia, S. K. Satyanarayanan, A. Ariel, J. A. Ribeil, L. Guillevin, M. A. Cassatella, A. Mueller, N. Thieblemont, P. Lamprecht, L. Mouthon, S. Perruche and V. Witko-Sarsat (2015). "Proteinase 3 on apoptotic cells disrupts immune silencing in autoimmune vasculitis." J Clin Invest 125(11): 4107-4121.

Mills, K. H. (2011). "TLR-dependent T cell activation in autoimmunity." Nat Rev Immunol 11(12): 807-822.

Moalli, F., S. Jaillon, A. Inforzato, M. Sironi, B. Bottazzi, A. Mantovani and C. Garlanda (2011). "Pathogen recognition by the long pentraxin PTX3." J Biomed Biotechnol 2011: 830421.

Mohammad, A. J., L. T. Jacobsson, A. D. Mahr, G. Sturfelt and M. Segelmark (2007). "Prevalence of Wegener's granulomatosis, microscopic polyangiitis, polyarteritis nodosa and Churg-Strauss syndrome within a defined population in southern Sweden." Rheumatology (Oxford) 46(8): 1329-1337.

Mohammad, A. J., L. T. Jacobsson, K. W. Westman, G. Sturfelt and M. Segelmark (2009). "Incidence and survival rates in Wegener's granulomatosis, microscopic polyangiitis, Churg-Strauss syndrome and polyarteritis nodosa." Rheumatology (Oxford) 48(12): 1560-1565.

Mohanan, S., S. Horibata, J. L. McElwee, A. J. Dannenberg and S. A. Coonrod (2013). "Identification of macrophage extracellular trap-like structures in mammary gland adipose tissue: a preliminary study." Front Immunol 4: 67.

Morgan, M. D., C. J. Day, K. P. Piper, N. Khan, L. Harper, P. A. Moss and C. O. Savage (2010). "Patients with Wegener's granulomatosis demonstrate a relative deficiency and functional impairment of T-regulatory cells." Immunology 130(1): 64-73.

Morshed, M., R. Hlushchuk, D. Simon, A. F. Walls, K. Obata-Ninomiya, H. Karasuyama, V. Djonov, A. Eggel, T. Kaufmann, H. U. Simon and S. Yousefi (2014). "NADPH oxidase-independent formation of extracellular DNA traps by basophils." J Immunol 192(11): 5314-5323.

Mullis, K. B. and F. A. Faloona (1987). "Specific synthesis of DNA in vitro via a polymerase-catalyzed chain reaction." Methods Enzymol 155: 335-350.

Muniain, M. A., J. C. Moreno and R. Gonzalez Campora (1986). "Wegener's granulomatosis in two sisters." Ann Rheum Dis 45(5): 417-421.

Murphy, K., P. Travers, M. Walport, M. Ehrenstein and C. A. Janeway (2008). Janeway's immunobiology. New York ; London, Garland Science.

Nakahira, K., S. Hisata and A. M. Choi (2015). "The Roles of Mitochondrial Damage-Associated Molecular Patterns in Diseases." Antioxid Redox Signal 23(17): 1329-1350.

Nakazawa, D., H. Shida, Y. Kusunoki, A. Miyoshi, S. Nishio, U. Tomaru, T. Atsumi and A. Ishizu (2016). "The responses of macrophages in interaction with neutrophils that undergo NETosis." J Autoimmun 67: 19-28.

Nakazawa, D., H. Shida, U. Tomaru, M. Yoshida, S. Nishio, T. Atsumi and A. Ishizu (2014). "Enhanced formation and disordered regulation of NETs in myeloperoxidase-ANCA-associated microscopic polyangiitis." J Am Soc Nephrol 25(5): 990-997.

Nakazawa, D., U. Tomaru, A. Suzuki, S. Masuda, R. Hasegawa, T. Kobayashi, S. Nishio, M. Kasahara and A. Ishizu (2012). "Abnormal conformation and impaired degradation of propylthiouracil-induced neutrophil 
extracellular traps: implications of disordered neutrophil extracellular traps in a rat model of myeloperoxidase antineutrophil cytoplasmic antibody-associated vasculitis." Arthritis Rheum 64(11): 3779-3787.

Nakazawa, D., U. Tomaru, C. Yamamoto, S. Jodo and A. Ishizu (2012). "Abundant neutrophil extracellular traps in thrombus of patient with microscopic polyangiitis." Front Immunol 3: 333.

Nathan, C. (2006). "Neutrophils and immunity: challenges and opportunities." Nat Rev Immunol 6(3): 173-182.

Nogueira, E., S. Hamour, D. Sawant, S. Henderson, N. Mansfield, K. M. Chavele, C. D. Pusey and A. D. Salama (2010). "Serum IL-17 and IL-23 levels and autoantigen-specific Th17 cells are elevated in patients with ANCAassociated vasculitis." Nephrol Dial Transplant 25(7): 2209-2217.

Nouel, A., P. Pochard, Q. Simon, I. Segalen, Y. Le Meur, J. O. Pers and S. Hillion (2015). "B-Cells induce regulatory T cells through TGF-beta/IDO production in A CTLA-4 dependent manner." J Autoimmun 59: 53-60.

Nouel, A., Q. Simon, C. Jamin, J. O. Pers and S. Hillion (2014). "Regulatory B cells: an exciting target for future therapeutics in transplantation." Front Immunol 5: 11

O'Neill, L. A., D. Golenbock and A. G. Bowie (2013). "The history of Toll-like receptors - redefining innate immunity." Nat Rev Immunol 13(6): 453-460.

O'Sullivan, K. M., C. Y. Lo, S. A. Summers, K. D. Elgass, P. J. McMillan, A. Longano, S. L. Ford, P. Y. Gan, P. G. Kerr, A. R. Kitching and S. R. Holdsworth (2015). "Renal participation of myeloperoxidase in antineutrophil cytoplasmic antibody (ANCA)-associated glomerulonephritis." Kidney Int 88(5): 1030-1046.

Ohlsson, S., T. Hellmark, K. Pieters, G. Sturfelt, J. Wieslander and M. Segelmark (2005). "Increased monocyte transcription of the proteinase 3 gene in small vessel vasculitis." Clin Exp Immunol 141(1): 174-182.

Ohlsson, S., J. Wieslander and M. Segelmark (2003). "Increased circulating levels of proteinase 3 in patients with anti-neutrophilic cytoplasmic autoantibodies-associated systemic vasculitis in remission." Clin Exp Immunol 131(3): 528-535.

Ohlsson, S., J. Wieslander and M. Segelmark (2004). "Circulating cytokine profile in anti-neutrophilic cytoplasmatic autoantibody-associated vasculitis: prediction of outcome?" Mediators of inflammation 13(4): 275283.

Ohlsson, S., J. Wieslander and M. Segelmark (2004). "Circulating cytokine profile in anti-neutrophilic cytoplasmatic autoantibody-associated vasculitis: prediction of outcome?" Mediators Inflamm 13(4): 275-283.

Ooi, J. D., A. R. Kitching and S. R. Holdsworth (2010). "Review: T helper 17 cells: their role in glomerulonephritis." Nephrology (Carlton) 15(5): 513-521.

Osorio, F. and C. Reis e Sousa (2011). "Myeloid C-type lectin receptors in pathogen recognition and host defense." Immunity 34(5): 651-664.

Paludan, S. R. and A. G. Bowie (2013). "Immune sensing of DNA." Immunity 38(5): 870-880.

Panda, S. and J. L. Ding (2015). "Natural Antibodies Bridge Innate and Adaptive Immunity." J Immunol 194(1): $13-20$.

Papayannopoulos, V., K. D. Metzler, A. Hakkim and A. Zychlinsky (2010). "Neutrophil elastase and myeloperoxidase regulate the formation of neutrophil extracellular traps." J Cell Biol 191(3): 677-691.

Patry, Y. C., D. C. Trewick, M. Gregoire, M. A. Audrain, A. M. Moreau, J. Y. Muller, K. Meflah and V. L. Esnault (2001). "Rats injected with syngenic rat apoptotic neutrophils develop antineutrophil cytoplasmic antibodies." J Am Soc Nephrol 12(8): 1764-1768.

Pendergraft, W. F., 3rd, G. A. Preston, R. R. Shah, A. Tropsha, C. W. Carter, Jr., J. C. Jennette and R. J. Falk (2004). "Autoimmunity is triggered by cPR-3(105-201), a protein complementary to human autoantigen proteinase-3." Nat Med 10(1): 72-79. 
Pepper, R. J., S. Hamour, K. M. Chavele, S. K. Todd, N. Rasmussen, S. Flint, P. A. Lyons, K. G. Smith, C. D. Pusey, H. T. Cook and A. D. Salama (2013). "Leukocyte and serum S100A8/S100A9 expression reflects disease activity in ANCA-associated vasculitis and glomerulonephritis." Kidney Int 83(6): 1150-1158.

Persson, U., B. Gullstrand, A. Pettersson, G. Sturfelt, L. Truedsson and M. Segelmark (2013). "A candidate gene approach to ANCA-associated vasculitis reveals links to the C3 and CTLA-4 genes but not to the IL1-Ra and Fcgamma-RIIa genes." Kidney Blood Press Res 37(6): 641-648.

Persson, U., L. Truedsson, K. W. Westman and M. Segelmark (1999). "C3 and C4 allotypes in anti-neutrophil cytoplasmic autoantibody (ANCA)-positive vasculitis." Clin Exp Immunol 116(2): 379-382.

Phillipson, M. and P. Kubes (2011). "The neutrophil in vascular inflammation." Nat Med 17(11): 1381-1390.

Philpott, D. J., M. T. Sorbara, S. J. Robertson, K. Croitoru and S. E. Girardin (2014). "NOD proteins: regulators of inflammation in health and disease." Nat Rev Immunol 14(1): 9-23.

Picot, J., C. L. Guerin, C. Le Van Kim and C. M. Boulanger (2012). "Flow cytometry: retrospective, fundamentals and recent instrumentation." Cytotechnology 64(2): 109-130.

Pilsczek, F. H., D. Salina, K. K. Poon, C. Fahey, B. G. Yipp, C. D. Sibley, S. M. Robbins, F. H. Green, M. G. Surette, M. Sugai, M. G. Bowden, M. Hussain, K. Zhang and P. Kubes (2010). "A novel mechanism of rapid nuclear neutrophil extracellular trap formation in response to Staphylococcus aureus." J Immunol 185(12): 7413 7425 .

Prendecki, M., T. Cairns and C. D. Pusey (2016). "Familial vasculitides: granulomatosis with polyangitis and microscopic polyangitis in two brothers with differing anti-neutrophil cytoplasm antibody specificity." Clin Kidney J 9(3): 429-431.

Prokopowicz, Z., J. Marcinkiewicz, D. R. Katz and B. M. Chain (2012). "Neutrophil myeloperoxidase: soldier and statesman." Arch Immunol Ther Exp (Warsz) 60(1): 43-54.

Radford, D. J., N. T. Luu, P. Hewins, G. B. Nash and C. O. Savage (2001). "Antineutrophil cytoplasmic antibodies stabilize adhesion and promote migration of flowing neutrophils on endothelial cells." Arthritis Rheum 44(12): 2851-2861.

Radford, D. J., C. O. Savage and G. B. Nash (2000). "Treatment of rolling neutrophils with antineutrophil cytoplasmic antibodies causes conversion to firm integrin-mediated adhesion." Arthritis Rheum 43(6): 1337-1345.

Rahmattulla, C., A. L. Mooyaart, D. van Hooven, J. W. Schoones, J. A. Bruijn, O. M. Dekkers and I. M. Bajema (2016). "Genetic variants in ANCA-associated vasculitis: a meta-analysis." Ann Rheum Dis 75(9): 1687-1692.

Rarok, A. A., C. A. Stegeman, P. C. Limburg and C. G. Kallenberg (2002). "Neutrophil membrane expression of proteinase 3 (PR3) is related to relapse in PR3-ANCA-associated vasculitis." J Am Soc Nephrol 13(9): 2232 2238 .

Rimbert, M., M. Hamidou, C. Braudeau, X. Puechal, L. Teixeira, H. Caillon, A. Neel, M. Audrain, L. Guillevin and R. Josien (2011). "Decreased numbers of blood dendritic cells and defective function of regulatory T cells in antineutrophil cytoplasmic antibody-associated vasculitis." PLoS One 6(4): e18734.

Rochael, N. C., A. B. Guimaraes-Costa, M. T. Nascimento, T. S. DeSouza-Vieira, M. P. Oliveira, L. F. Garcia e Souza, M. F. Oliveira and E. M. Saraiva (2015). "Classical ROS-dependent and early/rapid ROS-independent release of Neutrophil Extracellular Traps triggered by Leishmania parasites." Sci Rep 5: 18302.

Rodriguez-Bayona, B., A. Ramos-Amaya, J. J. Perez-Venegas, C. Rodriguez and J. A. Brieva (2010). "Decreased frequency and activated phenotype of blood CD27 IgD IgM B lymphocytes is a permanent abnormality in systemic lupus erythematosus patients." Arthritis Res Ther 12(3): R108.

Roth, A. J., J. D. Ooi, J. J. Hess, M. M. van Timmeren, E. A. Berg, C. E. Poulton, J. McGregor, M. Burkart, S. L. Hogan, Y. Hu, W. Winnik, P. H. Nachman, C. A. Stegeman, J. Niles, P. Heeringa, A. R. Kitching, S. Holdsworth, 
J. C. Jennette, G. A. Preston and R. J. Falk (2013). "Epitope specificity determines pathogenicity and detectability in ANCA-associated vasculitis." J Clin Invest 123(4): 1773-1783.

Saffarzadeh, M., C. Juenemann, M. A. Queisser, G. Lochnit, G. Barreto, S. P. Galuska, J. Lohmeyer and K. T. Preissner (2012). "Neutrophil extracellular traps directly induce epithelial and endothelial cell death: a predominant role of histones." PLoS One 7(2): e32366.

Sangaletti, S., C. Tripodo, C. Chiodoni, C. Guarnotta, B. Cappetti, P. Casalini, S. Piconese, M. Parenza, C. Guiducci, C. Vitali and M. P. Colombo (2012). "Neutrophil extracellular traps mediate transfer of cytoplasmic neutrophil antigens to myeloid dendritic cells toward ANCA induction and associated autoimmunity." Blood 120(15): 3007-3018

Saraiva, M. and A. O'Garra (2010). "The regulation of IL-10 production by immune cells." Nat Rev Immunol 10(3): 170-181.

Schmidt, A., N. Oberle and P. H. Krammer (2012). "Molecular mechanisms of treg-mediated T cell suppression." Front Immunol 3: 51.

Schreiber, A., F. C. Luft and R. Kettritz (2004). "Membrane proteinase 3 expression and ANCA-induced neutrophil activation." Kidney Int 65(6): 2172-2183.

Schreiber, A., H. Xiao, J. C. Jennette, W. Schneider, F. C. Luft and R. Kettritz (2009). "C5a receptor mediates neutrophil activation and ANCA-induced glomerulonephritis." J Am Soc Nephrol 20(2): 289-298.

Schroeder, H. W., Jr. and L. Cavacini (2010). "Structure and function of immunoglobulins." J Allergy Clin Immunol 125(2 Suppl 2): S41-52.

Schönrich, G. and M. J. Raftery (2016). "Neutrophil Extracellular Traps Go Viral." Front Immunol 7(366).

Segelmark, M., B. Persson, T. Hellmark and J. Wieslander (1997). "Binding and inhibition of myeloperoxidase (MPO): a major function of ceruloplasmin?" Clin Exp Immunol 108(1): 167-174.

Senovilla, L., L. Galluzzi, L. Zitvogel and G. Kroemer (2013). "Immunosurveillance as a regulator of tissue homeostasis." Trends Immunol 34(10): 471-481.

Seper, A., A. Hosseinzadeh, G. Gorkiewicz, S. Lichtenegger, S. Roier, D. R. Leitner, M. Rohm, A. Grutsch, J. Reidl, C. F. Urban and S. Schild (2013). "Vibrio cholerae evades neutrophil extracellular traps by the activity of two extracellular nucleases." PLoS Pathog 9(9): e1003614.

Serhan, C. N., P. A. Ward and D. W. Gilroy (2010). Fundamentals of inflammation. Cambridge, Cambridge University Press.

Sewell, R. F. and D. V. Hamilton (1992). "Time-associated Wegener's granulomatosis in two members of a family." Nephrol Dial Transplant 7(8): 882.

Sha, L. L., H. Wang, C. Wang, H. Y. Peng, M. Chen and M. H. Zhao (2016). "Autophagy is induced by antineutrophil cytoplasmic Abs and promotes neutrophil extracellular traps formation." Innate Immun.

Silva, F., A. M. Hummel, D. E. Jenne and U. Specks (2010). "Discrimination and variable impact of ANCA binding to different surface epitopes on proteinase 3, the Wegener's autoantigen." J Autoimmun 35(4): 299-308.

Soderberg, D. and M. Segelmark (2016). "Neutrophil Extracellular Traps in ANCA-Associated Vasculitis." Front Immunol 7: 256.

Stassen, P. M., R. P. Derks, C. G. Kallenberg and C. A. Stegeman (2008). "Venous thromboembolism in ANCAassociated vasculitis--incidence and risk factors." Rheumatology (Oxford) 47(4): 530-534.

Steinberg, B. E. and S. Grinstein (2007). "Unconventional roles of the NADPH oxidase: signaling, ion homeostasis, and cell death." Sci STKE 2007(379): pe11. 
Steinmetz, O. M., J. Velden, U. Kneissler, M. Marx, A. Klein, U. Helmchen, R. A. Stahl and U. Panzer (2008). "Analysis and classification of B-cell infiltrates in lupus and ANCA-associated nephritis." Kidney Int 74(4): 448457.

Stoiber, W., A. Obermayer, P. Steinbacher and W. D. Krautgartner (2015). "The Role of Reactive Oxygen Species (ROS) in the Formation of Extracellular Traps (ETs) in Humans." Biomolecules 5(2): 702-723.

Stone, J. H., P. A. Merkel, R. Spiera, P. Seo, C. A. Langford, G. S. Hoffman, C. G. Kallenberg, E. W. St Clair, A. Turkiewicz, N. K. Tchao, L. Webber, L. Ding, L. P. Sejismundo, K. Mieras, D. Weitzenkamp, D. Ikle, V. SeyfertMargolis, M. Mueller, P. Brunetta, N. B. Allen, F. C. Fervenza, D. Geetha, K. A. Keogh, E. Y. Kissin, P. A. Monach, T. Peikert, C. Stegeman, S. R. Ytterberg and U. Specks (2010). "Rituximab versus cyclophosphamide for ANCA-associated vasculitis." N Engl J Med 363(3): 221-232.

Sur Chowdhury, C., S. Giaglis, U. A. Walker, A. Buser, S. Hahn and P. Hasler (2014). "Enhanced neutrophil extracellular trap generation in rheumatoid arthritis: analysis of underlying signal transduction pathways and potential diagnostic utility." Arthritis Res Ther 16(3): R122.

Surmiak, M., M. Hubalewska-Mazgaj, K. Wawrzycka-Adamczyk, W. Szczeklik, J. Musial, T. Brzozowski and M. Sanak (2016). "Neutrophil-related and serum biomarkers in granulomatosis with polyangiitis support extracellular traps mechanism of the disease." Clin Exp Rheumatol 34(3 Suppl 97): 98-104.

Surmiak, M. P., M. Hubalewska-Mazgaj, K. Wawrzycka-Adamczyk, W. Szczeklik, J. Musial and M. Sanak (2015). "Circulating mitochondrial DNA in serum of patients with granulomatosis with polyangiitis." Clin Exp Immunol 181(1): 150-155.

Tang, S., Y. Zhang, S. W. Yin, X. J. Gao, W. W. Shi, Y. Wang, X. Huang, L. Wang, L. Y. Zou, J. H. Zhao, Y. J. Huang, L. Y. Shan, A. S. Gounni, Y. Z. Wu and J. B. Zhang (2015). "Neutrophil extracellular trap formation is associated with autophagy-related signalling in ANCA-associated vasculitis." Clin Exp Immunol 180(3): 408418 .

Todd, S. K., R. J. Pepper, J. Draibe, A. Tanna, C. D. Pusey, C. Mauri and A. D. Salama (2014). "Regulatory B cells are numerically but not functionally deficient in anti-neutrophil cytoplasm antibody-associated vasculitis." Rheumatology (Oxford) 53(9): 1693-1703.

Tomasson, G., P. C. Grayson, A. D. Mahr, M. Lavalley and P. A. Merkel (2012). "Value of ANCA measurements during remission to predict a relapse of ANCA-associated vasculitis--a meta-analysis." Rheumatology (Oxford) 51(1): 100-109.

Tretter, T., R. K. Venigalla, V. Eckstein, R. Saffrich, S. Sertel, A. D. Ho and H. M. Lorenz (2008). "Induction of CD4+ T-cell anergy and apoptosis by activated human B cells." Blood 112(12): 4555-4564.

Trinchieri, G. and A. Sher (2007). "Cooperation of Toll-like receptor signals in innate immune defence." Nat Rev Immunol 7(3): 179-190.

Unizony, S., N. Lim, D. J. Phippard, V. J. Carey, E. M. Miloslavsky, N. K. Tchao, D. Ikle, A. L. Asare, P. A. Merkel, P. A. Monach, P. Seo, E. W. St Clair, C. A. Langford, R. Spiera, G. S. Hoffman, C. G. Kallenberg, U. Specks and J. H. Stone (2015). "Peripheral CD5+ B cells in antineutrophil cytoplasmic antibody-associated vasculitis." Arthritis Rheumatol 67(2): 535-544.

Urban, C. F., D. Ermert, M. Schmid, U. Abu-Abed, C. Goosmann, W. Nacken, V. Brinkmann, P. R. Jungblut and A. Zychlinsky (2009). "Neutrophil extracellular traps contain calprotectin, a cytosolic protein complex involved in host defense against Candida albicans." PLoS Pathog 5(10): e1000639.

Urban, C. F., U. Reichard, V. Brinkmann and A. Zychlinsky (2006). "Neutrophil extracellular traps capture and kill Candida albicans yeast and hyphal forms." Cell Microbiol 8(4): 668-676.

Wada, N., M. Mukai, M. Kohno, A. Notoya, T. Ito and N. Yoshioka (2002). "Prevalence of serum antimyeloperoxidase antineutrophil cytoplasmic antibodies (MPO-ANCA) in patients with Graves' disease treated with propylthiouracil and thiamazole." Endocr J 49(3): 329-334. 
van Rossum, A. P., A. A. Rarok, M. G. Huitema, G. Fassina, P. C. Limburg and C. G. Kallenberg (2004). "Constitutive membrane expression of proteinase 3 (PR3) and neutrophil activation by anti-PR3 antibodies." J Leukoc Biol 76(6): 1162-1170.

Wang, C., S. J. Gou, D. Y. Chang, F. Yu, M. H. Zhao and M. Chen (2013). "Association of circulating level of high mobility group box 1 with disease activity in antineutrophil cytoplasmic autoantibody-associated vasculitis." Arthritis Care Res (Hoboken) 65(11): 1828-1834.

Wang, H., T. Li, S. Chen, Y. Gu and S. Ye (2015). "Neutrophil Extracellular Trap Mitochondrial DNA and Its Autoantibody in Systemic Lupus Erythematosus and a Proof-of-Concept Trial of Metformin." Arthritis Rheumatol 67(12): 3190-3200.

Wang, H., L. L. Sha, T. T. Ma, L. X. Zhang, M. Chen and M. H. Zhao (2016). "Circulating Level of Neutrophil Extracellular Traps Is Not a Useful Biomarker for Assessing Disease Activity in Antineutrophil Cytoplasmic Antibody-Associated Vasculitis." PLoS One 11(2): e0148197.

Wang, H., C. Wang, M. H. Zhao and M. Chen (2015). "Neutrophil extracellular traps can activate alternative complement pathways." Clin Exp Immunol 181(3): 518-527.

Watts, R., S. Lane, T. Hanslik, T. Hauser, B. Hellmich, W. Koldingsnes, A. Mahr, M. Segelmark, J. W. CohenTervaert and D. Scott (2007). "Development and validation of a consensus methodology for the classification of the ANCA-associated vasculitides and polyarteritis nodosa for epidemiological studies." Ann Rheum Dis 66(2): 222-227.

Watts, R. A., A. Mahr, A. J. Mohammad, P. Gatenby, N. Basu and L. F. Flores-Suarez (2015). "Classification, epidemiology and clinical subgrouping of antineutrophil cytoplasmic antibody (ANCA)-associated vasculitis." Nephrol Dial Transplant 30 Suppl 1: i14-22.

Weiner, M. and M. Segelmark (2016). "The clinical presentation and therapy of diseases related to anti-neutrophil cytoplasmic antibodies (ANCA)." Autoimmun Rev.

Venhoff, N., L. Niessen, M. Kreuzaler, A. G. Rolink, F. Hassler, M. Rizzi, R. E. Voll and J. Thiel (2014). "Reconstitution of the peripheral B lymphocyte compartment in patients with ANCA-associated vasculitides treated with rituximab for relapsing or refractory disease." Autoimmunity 47(6): 401-408.

Wibisono, D., E. Csernok, P. Lamprecht, J. U. Holle, W. L. Gross and F. Moosig (2010). "Serum HMGB1 levels are increased in active Wegener's granulomatosis and differentiate between active forms of ANCA-associated vasculitis." Ann Rheum Dis 69(10): 1888-1889.

Vidarsson, G., G. Dekkers and T. Rispens (2014). "IgG subclasses and allotypes: from structure to effector functions." Front Immunol 5: 520.

Wiik, A. (2009). "Clinical and pathophysiological significance of anti-neutrophil cytoplasmic autoantibodies in vasculitis syndromes." Mod Rheumatol 19(6): 590-599.

Wilde, B., M. Thewissen, J. Damoiseaux, S. Knippenberg, M. Hilhorst, P. van Paassen, O. Witzke and J. W. Cohen Tervaert (2013). "Regulatory B cells in ANCA-associated vasculitis." Ann Rheum Dis 72(8): 1416-1419.

Villanueva, E., S. Yalavarthi, C. C. Berthier, J. B. Hodgin, R. Khandpur, A. M. Lin, C. J. Rubin, W. Zhao, S. H. Olsen, M. Klinker, D. Shealy, M. F. Denny, J. Plumas, L. Chaperot, M. Kretzler, A. T. Bruce and M. J. Kaplan (2011). "Netting neutrophils induce endothelial damage, infiltrate tissues, and expose immunostimulatory molecules in systemic lupus erythematosus." J Immunol 187(1): 538-552.

Willcocks, L. C., P. A. Lyons, A. J. Rees and K. G. Smith (2010). "The contribution of genetic variation and infection to the pathogenesis of ANCA-associated systemic vasculitis." Arthritis Res Ther 12(1): 202.

Witko-Sarsat, V., P. Lesavre, S. Lopez, G. Bessou, C. Hieblot, B. Prum, L. H. Noel, L. Guillevin, P. Ravaud, I. Sermet-Gaudelus, J. Timsit, J. P. Grunfeld and L. Halbwachs-Mecarelli (1999). "A large subset of neutrophils expressing membrane proteinase 3 is a risk factor for vasculitis and rheumatoid arthritis." J Am Soc Nephrol 10(6): 1224-1233. 
von Bruhl, M. L., K. Stark, A. Steinhart, S. Chandraratne, I. Konrad, M. Lorenz, A. Khandoga, A. Tirniceriu, R. Coletti, M. Kollnberger, R. A. Byrne, I. Laitinen, A. Walch, A. Brill, S. Pfeiler, D. Manukyan, S. Braun, P. Lange, J. Riegger, J. Ware, A. Eckart, S. Haidari, M. Rudelius, C. Schulz, K. Echtler, V. Brinkmann, M. Schwaiger, K. T. Preissner, D. D. Wagner, N. Mackman, B. Engelmann and S. Massberg (2012). "Monocytes, neutrophils, and platelets cooperate to initiate and propagate venous thrombosis in mice in vivo." J Exp Med 209(4): 819-835.

von Kockritz-Blickwede, M., O. Goldmann, P. Thulin, K. Heinemann, A. Norrby-Teglund, M. Rohde and E. Medina (2008). "Phagocytosis-independent antimicrobial activity of mast cells by means of extracellular trap formation." Blood 111(6): 3070-3080.

Xiao, H., D. J. Dairaghi, J. P. Powers, L. S. Ertl, T. Baumgart, Y. Wang, L. C. Seitz, M. E. Penfold, L. Gan, P. Hu, B. Lu, N. P. Gerard, C. Gerard, T. J. Schall, J. C. Jaen, R. J. Falk and J. C. Jennette (2014). "C5a receptor (CD88) blockade protects against MPO-ANCA GN." J Am Soc Nephrol 25(2): 225-231.

Xiao, H., P. Heeringa, P. Hu, Z. Liu, M. Zhao, Y. Aratani, N. Maeda, R. J. Falk and J. C. Jennette (2002). "Antineutrophil cytoplasmic autoantibodies specific for myeloperoxidase cause glomerulonephritis and vasculitis in mice." J Clin Invest 110(7): 955-963.

Xiao, H., A. Schreiber, P. Heeringa, R. J. Falk and J. C. Jennette (2007). "Alternative complement pathway in the pathogenesis of disease mediated by anti-neutrophil cytoplasmic autoantibodies." Am J Pathol 170(1): 52-64.

Xie, G., D. Roshandel, R. Sherva, P. A. Monach, E. Y. Lu, T. Kung, K. Carrington, S. S. Zhang, S. L. Pulit, S. Ripke, S. Carette, P. F. Dellaripa, J. C. Edberg, G. S. Hoffman, N. Khalidi, C. A. Langford, A. D. Mahr, E. W. St Clair, P. Seo, U. Specks, R. F. Spiera, J. H. Stone, S. R. Ytterberg, S. Raychaudhuri, P. I. de Bakker, L. A. Farrer, C. I. Amos, P. A. Merkel and K. A. Siminovitch (2013). "Association of granulomatosis with polyangiitis (Wegener's) with HLA-DPB1*04 and SEMA6A gene variants: evidence from genome-wide analysis." Arthritis Rheum 65(9): 2457-2468.

Xing, G. Q., M. Chen, G. Liu, P. Heeringa, J. J. Zhang, X. Zheng, J. E, C. G. Kallenberg and M. H. Zhao (2009). "Complement activation is involved in renal damage in human antineutrophil cytoplasmic autoantibody associated pauci-immune vasculitis." J Clin Immunol 29(3): 282-291.

Yang, H., M. H. Biermann, J. M. Brauner, Y. Liu, Y. Zhao and M. Herrmann (2016). "New Insights into Neutrophil Extracellular Traps: Mechanisms of Formation and Role in Inflammation." Front Immunol 7(302).

Yang, J. J., G. A. Preston, W. F. Pendergraft, M. Segelmark, P. Heeringa, S. L. Hogan, J. C. Jennette and R. J. Falk (2001). "Internalization of proteinase 3 is concomitant with endothelial cell apoptosis and internalization of myeloperoxidase with generation of intracellular oxidants." Am J Pathol 158(2): 581-592.

Yates, M., R. A. Watts, I. M. Bajema, M. C. Cid, B. Crestani, T. Hauser, B. Hellmich, J. U. Holle, M. Laudien, M. A. Little, R. A. Luqmani, A. Mahr, P. A. Merkel, J. Mills, J. Mooney, M. Segelmark, V. Tesar, K. Westman, A. Vaglio, N. Yalcindag, D. R. Jayne and C. Mukhtyar (2016). "EULAR/ERA-EDTA recommendations for the management of ANCA-associated vasculitis." Ann Rheum Dis 75(9): 1583-1594.

Yipp, B. G., B. Petri, D. Salina, C. N. Jenne, B. N. Scott, L. D. Zbytnuik, K. Pittman, M. Asaduzzaman, K. Wu, H. C. Meijndert, S. E. Malawista, A. de Boisfleury Chevance, K. Zhang, J. Conly and P. Kubes (2012). "Infectioninduced NETosis is a dynamic process involving neutrophil multitasking in vivo." Nat Med 18(9): 1386-1393.

Yoshida, M., M. Sasaki, K. Sugisaki, Y. Yamaguchi and M. Yamada (2013). "Neutrophil extracellular trap components in fibrinoid necrosis of the kidney with myeloperoxidase-ANCA-associated vasculitis." Clin Kidney J 6(3): 308-312.

Yoshida, M., M. Yamada, Y. Sudo, T. Kojima, T. Tomiyasu, N. Yoshikawa and T. Oda (2016). "Myeloperoxidase anti-neutrophil cytoplasmic antibody affinity is associated with the formation of neutrophil extracellular traps in the kidney and vasculitis activity in myeloperoxidase anti-neutrophil cytoplasmic antibody-associated microscopic polyangiitis." Nephrology (Carlton).

Yousefi, S., J. A. Gold, N. Andina, J. J. Lee, A. M. Kelly, E. Kozlowski, I. Schmid, A. Straumann, J. Reichenbach, G. J. Gleich and H. U. Simon (2008). "Catapult-like release of mitochondrial DNA by eosinophils contributes to antibacterial defense." Nat Med 14(9): 949-953. 
Yousefi, S., C. Mihalache, E. Kozlowski, I. Schmid and H. U. Simon (2009). "Viable neutrophils release mitochondrial DNA to form neutrophil extracellular traps." Cell Death Differ 16(11): 1438-1444.

Zha, B., L. Wang, X. Liu, J. Liu, Z. Chen, J. Xu, L. Sheng, Y. Li and Y. Chu (2012). "Decrease in proportion of CD19+ CD24(hi) CD27+ B cells and impairment of their suppressive function in Graves' disease." PLoS One 7(11): e49835. 


\section{Original Publications}

The articles associated with this thesis have been removed for copyright reasons. For more details about these see:

http://urn.kb.se/resolve?urn=urn:nbn:se:liu:diva-132327 